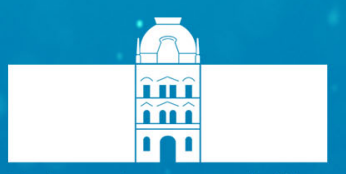

Univerzitetna založba Univerze v Mariboru

\title{
DOSTOPNOST DIGITALNIH PRODUKTOV ZA VSE
}

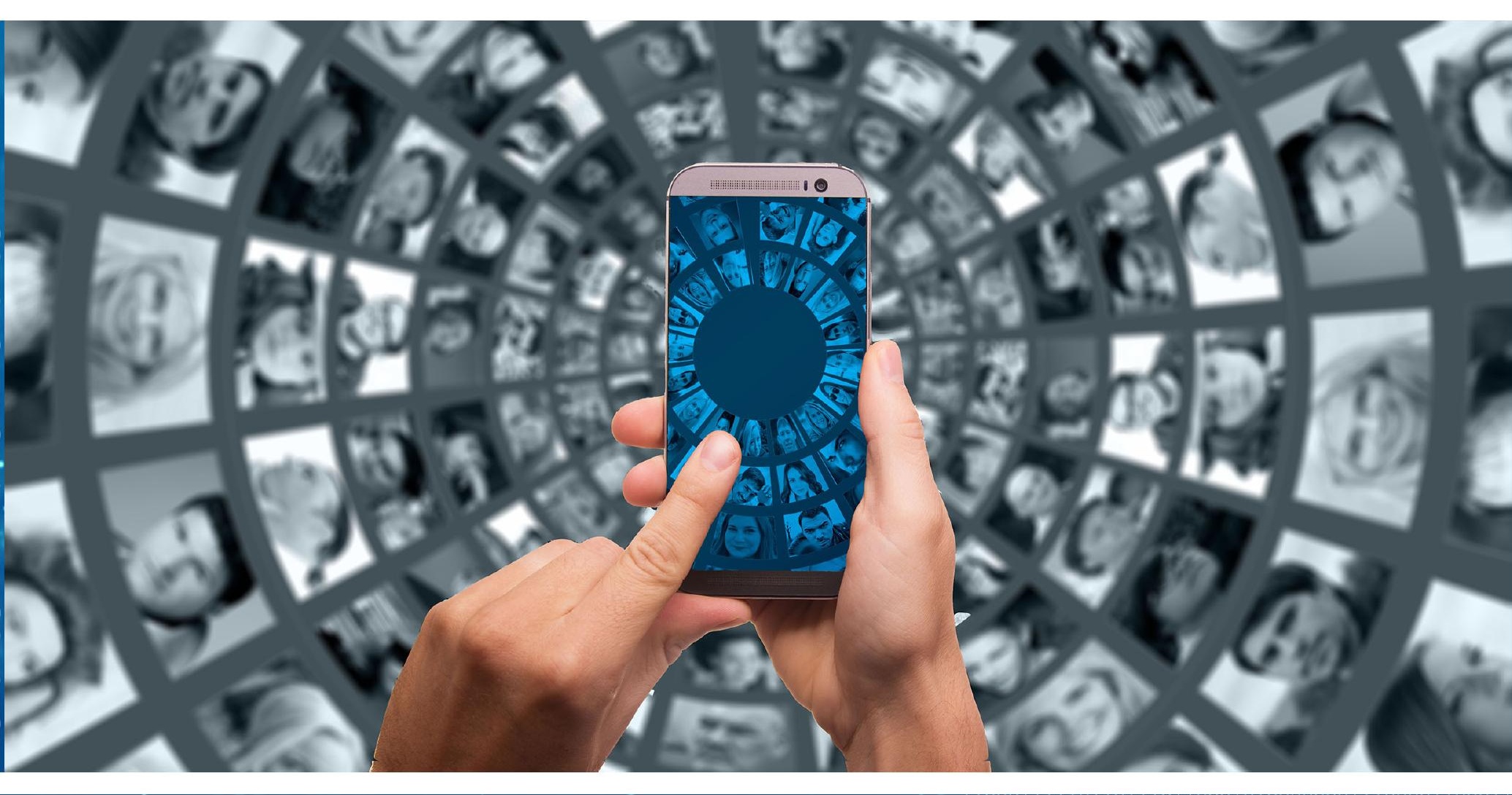


10110000110110001111101101110110001010000000111 00010110000110110001111101101110110001010000000 1100011111011011101100010100000001110000110001 00011011000111110110111011000101000000011100001 01100001101100011111011011101100010100000001110 01101100011111011011101100010100000001110000110 11000111110110111011000101000000011100001100011 10001011000011011000111110110111011000101000000 11000011011000111110110111011000101000000011100 10000110110001111101101110110001010000000111000 00110110001111101101110110001010000000111000011 01100001101100011111011011101100010100000001110 00101100001101100011111011011101100010100000001 10000110110001111101101110110001010000000111000 1100011111011011101100010100000001110000110001 00110110001111101101110110001010000000111000011 10110000110110001111101101110110001010000000111 00010110000110110001111101101110110001010000000 11000011011000111110110111011000101000000011100 01100011111011011101100010100000001110000110001 00011011000111110110111011000101000000011100001 01100001101100011111011011101100010100000001110 01101100011111011011101100010100000001110000110 11000111110110111011000101000000011100001100011 100010110000110110001110110111011000101000000 11000011011000111110110111011000101000000011100 10000110110001111101101110110001010000000111000 00110110001111101101110110001010000000111000011 01100001101100011111011011101100010100000001110 010110000110110001111101101110110001010000000 10000110110001111101101110110001010000000111000 11000111110110111011000101000000011100001100011 00110110001111101101110110001010000000111000011 10110000110110001111101101110110001010000000111 00010110000110110001111101101110110001010000000 11000011011000111110110111011000101000000011100 01100011111011011101100010100000001110000110001 00011011000111110110111011000101000000011100001 01100001101100011111011011101100010100000001110 01101100011111011011101100010100000001110000110 11000111110110111011000101000000011100001100011 10001011000011011000111110110111011000101000000 11000011011000111110110111011000101000000011100 1000011011000111110110111011000101000000011100 0011011000111110110111011000101000000011100001 01100001101100011111011011101100010100000001110 00101100001101100011111011011101100010100000001 10000110110001111101101110110001010000000111000 11000111110110111011000101000000011100001100011 0011011000111110110111011000101000000011100001 $1011000011011000111110110111011000101000000011^{11}$ 00010110000110110001111101101110110001010000000 11000011011000111110110111011000101000000011100 01100011111011011101100010100000001110000110001 00011011000111110110111011000101000000011100001 $01100001101100011111,01101110110001,0100000001110$ 01101100011111011011101100010100000001110000110 11000111110110111011000101000000011100001100011 10001011000011011000111110110111011000101000000 11000011011000111110110111011000101000000011100 10000110110001111101101110110001010000000111000 00110110001111101101110110001010000000111000011 01100001101100011111011011101100010100000001110 00101100001101100011111011011101100010100000001 10000110110001111101101110110001010000000111000 1100011111011011101100010100000001110000110001 00110110001111101101110110001010000000111000011 10110000110110001111101101110110001010000000111 00010110000110110001111101101110110001010000000 11000011011000111110110111011000101000000011100 01100011111011011101100010100000001110000110001 00011011000111110110111011000101000000011100001 01100001101100011111011011101100010100000001110 01101100011111011011101100010100000001110000110 11000111110110111011000101000000011100001100011 10001011000011011000111110110111011000101000000 11000011011000111110110111011000101000000011100 10000110110001111101101110110001010000000111000 00110110001111101101110110001010000000111000011 01100001101100011111011011101100010100000001110 00101100001101100011111011011101100010100000001 10000110110001111101101110110001010000000111000 11000111110110111011000101000000011100001100011 00110110001111101101110110001010000000111000011 10110000110110001111101101110110001010000000111 00010110000110110001111101101110110001010000000 11000011011000111110110111011000101000000011100 01100011111011011101100010100000001110000110001 00011011000111110110111011000101000000011100001 01100001101100011111011011101100010100000001110 01101100011111011011101100010100000001110000110 11000111110110111011000101000000011100001100011 10001011000011011000111110110111011000101000000 11000011011000111110110111011000101000000011100
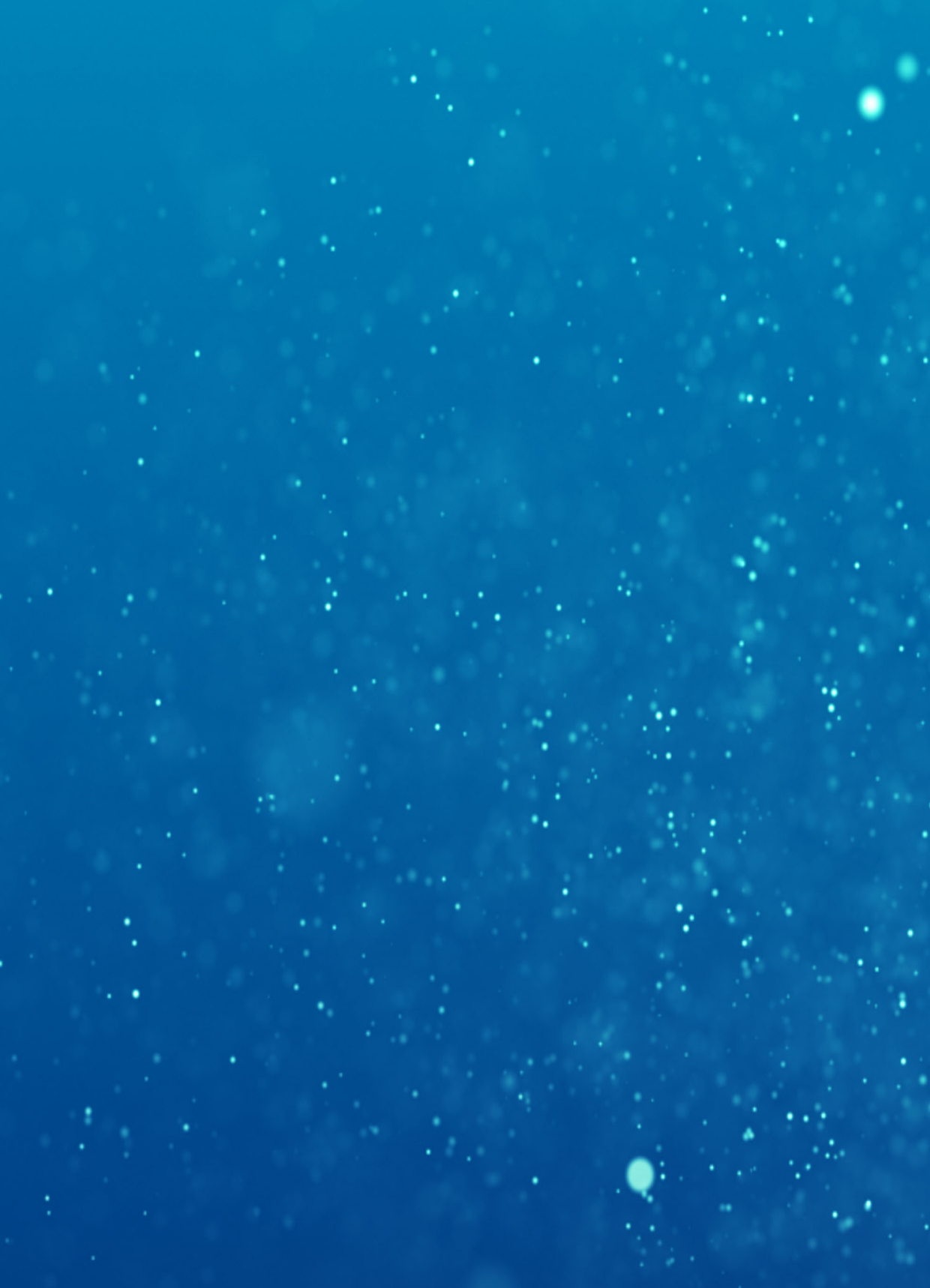

$\cdot$

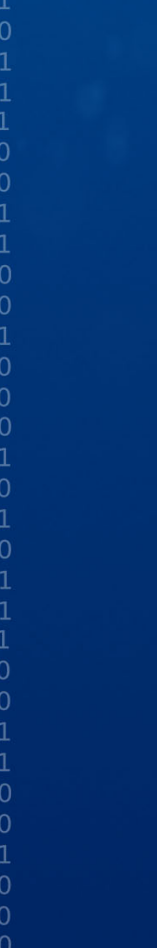




\section{DOSTOPNOST DIGITALNIH PRODUKTOV ZA VSE}

Avtor

Matjaž Debevc

Marec 2021 
Naslov Dostopnost digitalnih produktov za vse

Title Accessibility of Digital Products for All

Avtor Matjaž Debevc

Author (Univerza v Mariboru, Fakulteta za elektrotehniko, računalništvo in informatiko)

Recenzija Marjan Krašna

Review (Univerza v Mariboru, Pedagoška fakulteta)

Viktorija Florjančič

(Univerza na Primorskem, Fakulteta za management)

Jezikovni pregled

Language editing

Tehnični uredniki Jan Perša

Technicals (Univerza v Mariboru, Univerzitetna založba)

Oblikovanje ovitka

Cover designer

Grafike na ovitku

Cover graphics

Grafične priloge

Graphic material

Založnik

Published by

Izdajatelj Univerza v Mariboru

Co-published by Fakulteta za elektrotehniko, računalništvo in informatiko

Koroška cesta 46. 2000 Maribor, Slovenija

https://www.feri.um.si, feri@um.si

$\begin{array}{lr}\text { Izdaja } & \text { Izdano } \\ \text { Edition } & \text { Prva izdaja }\end{array}$

Maribor, marec 2021

Vrsta publikacije Publication type
E-knjiga
Jan Perša

Wlan (avtor geralt) in blue-stars (avtor tommyvideo) s pixabay.com (CCO)

Lilijana Sušnik in avtor.

Slomškov trg 15, 2000 Maribor, Slovenija

https://press.um.si, zalozba@um.si

Dostopno na

Available at
Matjaž Sušnik

(CWIT, s. p.)

Lilijana Sušnik

(CWIT, s. p.)

https://press.um.si/index.php/ump/catalog/book/526

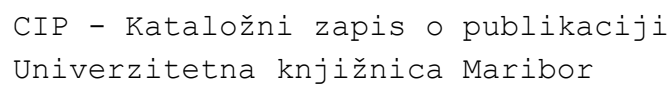

CIP - Kataložni zapis o publikaciji

Univerzitetna knjižnica Maribor

$004.5-056.26(0.034 .2)$

DEBEVC, Matjaž

Dostopnost digitalnih produktov za vse [Elektronski vir] / avtor Matjaž Debevc. 1. izd. - E-knjiga. - Maribor : Univerza v Mariboru, Univerzitetna založba, 2021

Način dostopa (URL):

https://press.um.si/index.php/ump/catalog/ book/ 526

ISBN 978-961-286-426-2 (pdf)

doi: $10.18690 / 978-961-286-426-2$

COBISS.SI-ID 50454531

\section{(c)(1) $\Theta$

BY NC ND

(C) Univerza v Mariboru, Univerzitetna založba

/ University of Maribor, University Press

Besedilo / Text (C) Debevec, 2021

To delo je objavljeno pod licenco Creative Commons Priznanje avtorstva - Nekomercialno-Brez predelav 4.0 Mednarodna. / This work is licensed under the Creative Commons Attribution-NonCommercial-NoDerivs 4.0 International License.

Uporabnikom se dovoli brez predelave avtorskega dela reproduciranje, distribuiranje, dajanje $\mathrm{v}$ najem in priobčitev javnosti samega izvirnega avtorskega dela, pod pogojem, da navedejo avtorja in da ne gre za komercialno uporabo

Vsa gradiva tretjih oseb v tej knjigi so objavljena pod licenco Creative Commons, razen če to ni navedeno drugače. Če želite ponovno uporabiti gradivo tretjih oseb, ki ni zajeto v licenci Creative Commons, boste morali pridobiti dovoljenje neposredno od imetnika avtorskih pravic.

https://creativecommons.org/licenses/by-nc-nd/4.0/

DOI https://doi.org/10.18690/978-961-286-426-2
Odgovorna oseba založnika prof. dr. Zdravko Kačič, For publisher rektor Univerze v Mariboru 
0010110000110110001111101101110110001010000000

1000011011000111110110111011000101000000011100 01100011111011011101100010100000001110000110001 0011011000111110110111011000101000000011100001 01100001101100011111011011101100010100000001110 1101100011111011011101100010100000001110000110 1000111110110111011000101000000011100001100011 10001011000011011000111110110111011000101000000 1000011011000111110110111011000101000000011100 10000110110001111101101110110001010000000111000 00110110001111101101110110001010000000111000011 01100001101100011111011011101100010100000001110 00101100001101100011111011011101100010100000001 10000110110001111101101110110001010000000111000 11000111110110111011000101000000011100001100011 0110110001111101101110110001010000000111000011 0110000110110001111101101110110001010000000111 0010110000110110001111101101110110001010000000 1000011011000111110110111011000101000000011100 1100011111011011101100010100000001110000110001 0011011000111110110111011000101000000011100001 01100001101100011111011011101100010100000001110 01101100011111011011101100010100000001110000110 1000111110110111011000101000000011100001100011 100010110000110110001110110111011000101000000 1000011011000111110110111011000101000000011100 0000110110001111101101110110001010000000111000 0110110001111101101110110001010000000111000011 01100001101100011111011011101100010100000001110 0101100001101100011111011011101100010100000601 0000110110001111101101110110001010000000111000 11000111110110111011000101000000011100001100011 0110110001111101101110110001010000000111000011 0110000110110001111101101110110001010000000111 0010110000110110001111101101110110001010000000 1000011011000111110110111011000101000000011100 1100011111011011101100010100000001110000110001 0011011000111110110111011000101000000011100001 100001101100011111011011101100010100000001110 1101100011111011011101100010100000001110000110 1000111110110111011000101000000011100001100011 0001011000011011000111110110111011000101000000 1000011011000111110110111011000101000000011100 10000110110001111101101110110001010000000111008 0110110001111101101110110001010000000111000011 1100001101100011111011011101100010100000001110 0101100001101100011111011011101100010100000001 0000110110001111101101110110001010000000111000 11000111110110111011000101000000011100001100011 0110110001111101101110110001010000000111000011 0110000110110001111101101110110001010000000111 0010110000110110001111101101110110001010000000 1000011011000111110110111011000101000000011100 100011111011011101100010100000001110000110001 0011011000111110110111011000101000000011100001 100001101100011111 D1101110110001,0100000001110 1101100011111011011101100010100000001110000110 1000111110110111011000101000000011100001100011 0001011000011011000111110110111011000101000000 1000011011000111110110111011000101000000011100 0000110110001111101101110110001010000000111000 110110001111101101110110001010000000111000011 100001101100011111011011101100010100000001110 0101100001101100011111011011101100010100000001 000110110001111101101110110001010000000111000 100011111011011101100010100000001110000110001 0110110001111101101110110001010000000111000011 $11000011011000111110110111011000101000000^{0} 0111$ 010110000110110001111101101110110001010000000 000011011000111110110111011000101000000011100 100011111011011101100010100000001110000110001 01101100011110110111011000101000000011100001 100001101100011111011011101100010100000001110 1000111110110111011000101000000011100001100011 001011000011011000111110110111011000101000000 0110110001111101101110110001010000000111000 (1) 100001101100011111011011101100010100000001110 101100001101100011111011011101100010100000001 000110110001111101101110110001010000000111000 (110110001111101101110110001010000000111000011 1100011011000111110110111011000101000000111 1000011011000111110110111011000101000000011100 100011111011011101100010100000001110000110001 0011011000111110110111011000101000000011100001 1100001101100011111011011101100010100000001110 1.01100011111011011101100010100000001110000110 (1) 
1011000011011000111110110111011000101000000011 1100001101100011111011011101100010100000001110 0110001111101101110110001010000000111000011000 0001101100011111011011101100010100000001110000 0110000110110001111101101110110001010000000111 0110110001111101101110110001010000000111000011 1100011111011011101100010100000001110000110001 1000101100001101100011111011011101100010100000 1100001101100011111011011101100010100000001110 1000011011000111110110111011000101000000011100 0011011000111110110111011000101000000011100001 0110000110110001111101101110110001010000000111 0010110000110110001111101101110110001010000000 1000011011000111110110111011000101000000011100 1100011111011011101100010100000001110000110001 0011011000111110110111011000101000000011100001 1011000011011000111110110111011000101000000011 0001011000011011000111110110111011000101000000 1100001101100011111011011101100010100000001110 0110001111101101110110001010000000111000011000 0001101100011111011011101100010100000001110000 0110000110110001111101101110110001010000000111 0110110001111101101110110001010000000111000011 1100011111011011101100010100000001110000110001 1000101100001101100011111011011101100010100000 1100001101100011111011011101100010100000001110 1000011011000111110110111011000101000000011100 0011011000111110110111011000101000000011100001 0110000110110001111101101110110001010000000111 0010110000110110001111101101110110001010000000 1000011011000111110110111011000101000000011100 1100011111011011101100010100000001110000110001

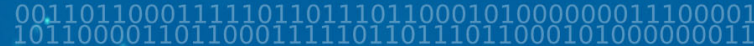
0001011000011011000111110110111011000101000000 1100001101100011111011011101100010100000001110 0110001111101101110110001010000000111000011000 00Q1101100Q11111011011101100010100000001110000 0110000110110001111101101110110001010000000111 • 0110110001111101101110110001010000000111000011 1100011111011011101100010100000001110000110001 1000101100001101100011111011011101100010100000 1100001101100011111011011101100010100000001110 100,0011011000111110110111011000101000000011100 0011011000111110110111011000101000000011100001 0110000110110001111101101110110001010000000111 0010110000110110001111101101110110001010000000 1000011011000111110110111011000101000000011100 .1100011111011011101100010100000001110000110001 0011011000111110110111011,00101000000011100001 1011000011011000111110110111011000101000000011 0001011000011011000111110110111011000101000000 1100001101100011111011011101100010100000001110 0110001111101101110110001010000000111000011000 0001101100011111011011101100010100000001110000 0110000110110001111101101110110001010000000111 $01101100 Q 1111101101110110001010000000111000011$ 1100011111011011101100010100000001110000110001 1000101100001101100011111011011101100010100000 1100001101100011111011011101100010100000001110 1000011011000111110110111011000101000000011100 0011011000111110110111011000101000000011100001 0110000110110001111101101210110001010000000111 .0010110000110110001111101101110110001010000000

: $\quad 1000011011000111110110111011000101000000011100$ 110001111101101110110001010000000111000011000 0011011000111110110111011000101000000011100001 1011000011011000111110110111011000101000000011 0001011000011011000111110110111011000101000000 1100001101100011111011011101100010100000001110 0110001111101101110110001010000000111000011000 0001101100011111011011101100010100000001110000

. 0110000110110001111101101110110001010000000111 0110110001111101101110110001010000000111000011 1100011111011011101100010100000001110000110001 1000101100001101100011111011011701100010100000 1100001101100011111011011101100010100000001110 100.001101100011111011011101100010100000001110 0011011000111110110111011000101000000011100001 0110000110110001111101101110110001010000000111 0010110000110110001111101101110110001010000000 1000011011000111110110111011000101000000011100 1100011111011011101100010100000001110000110001 0011011000111110110111011000101000000011100001 1011000011011000111110110111011000101000000011 0001011000011011000111110110111011000101000000 1100001101100011111011011101100010100000001110 0110001111,101101110110001010000000111000011000 0001101100011111011011101100010100000001110000 0110000110110001111101101110110001010000000111 0110110001111101101110110001010000000111000011 1100011111011011101100010100000001110000110001 1000101100001101100011111011011101100010100000 1100001101100011111011011101100010100000001110 100001101100011111011011101100010100000001110 


\section{Kazalo}

Predgovor.

1.1 Vzpon informacijske in komunikacijske tehnologije

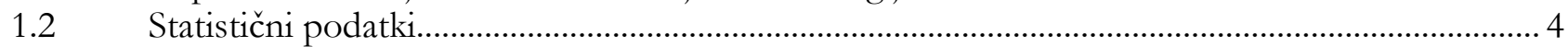

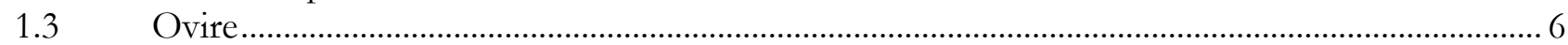

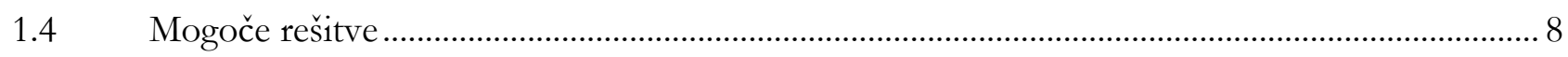

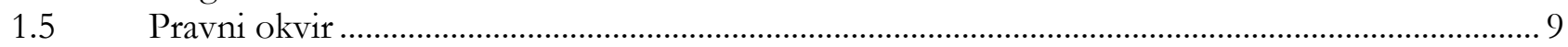

$2 \quad$ Značilnosti in zahteve oseb $\mathrm{z}$ različnimi oblikami oviranost.....................................13

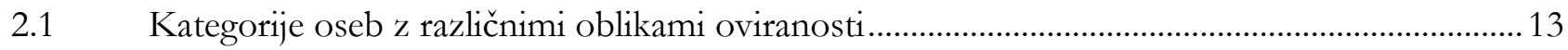

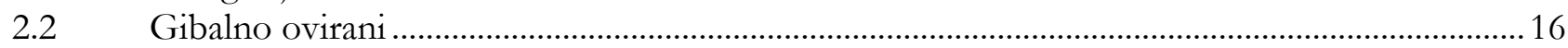

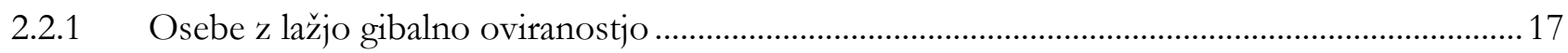

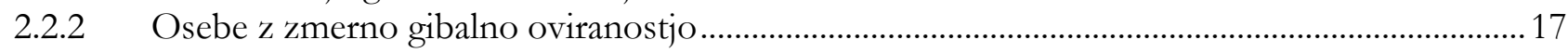

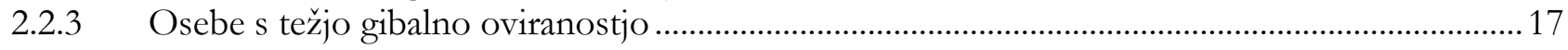

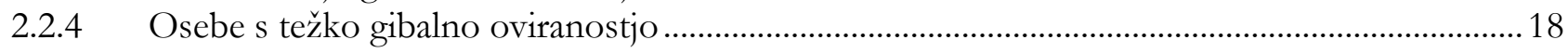

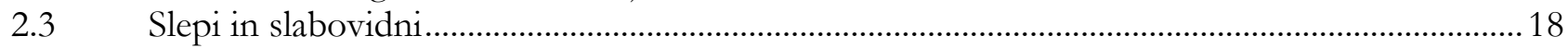

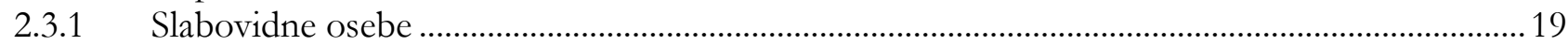

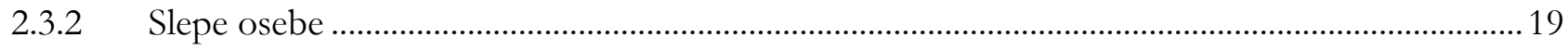

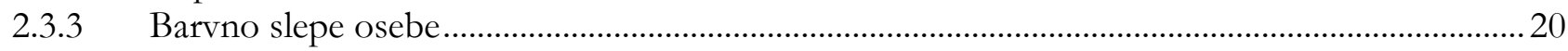

2.3.4 Fotosenzibilne osebe

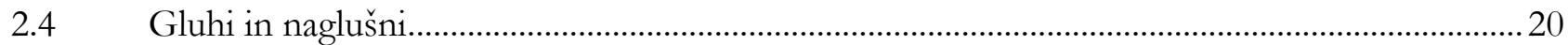

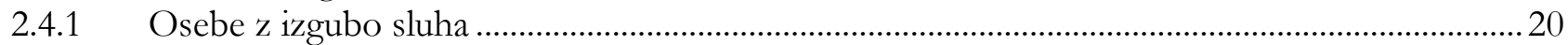

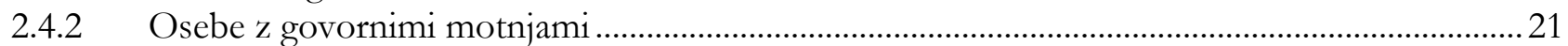

2.5 Osebe s težavami v kognitivnem funkcioniranju......................................................................22

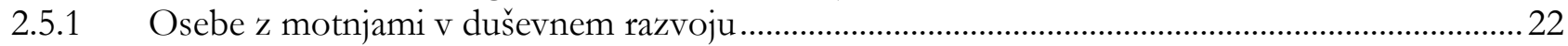

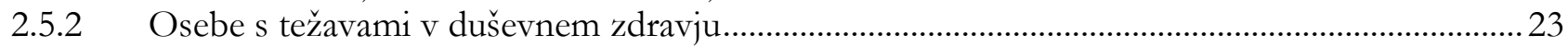

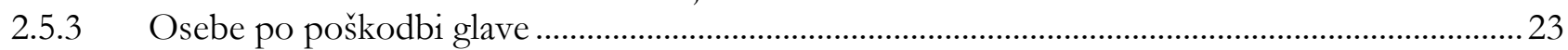

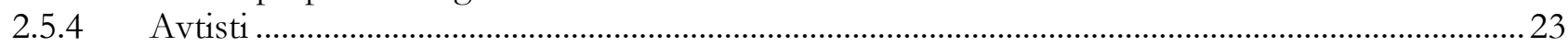

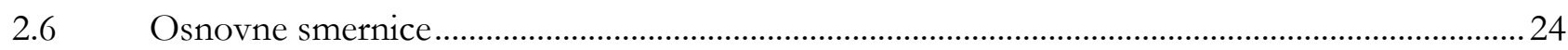

3 Osnovna pravila in načela dostopnosti ter priporočila in standardi ............................25

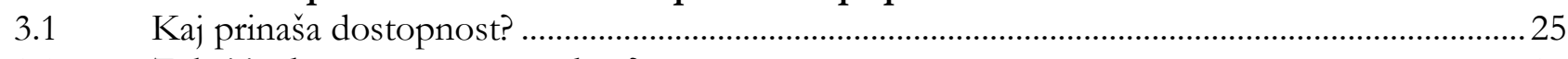

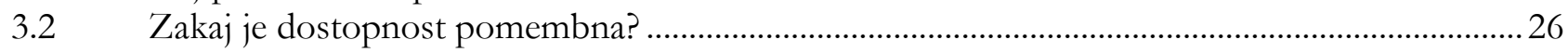

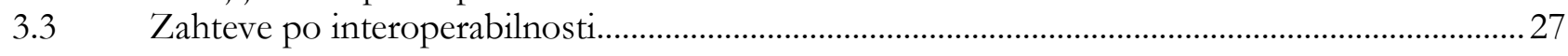

S.4 Smernice za dostopnost spletnih vsebin - WCAG ................................................................ 28

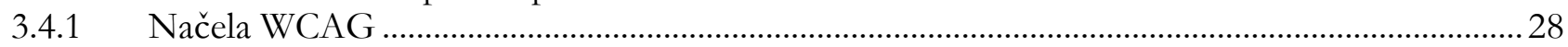

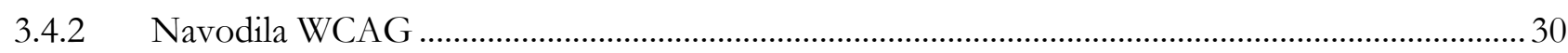

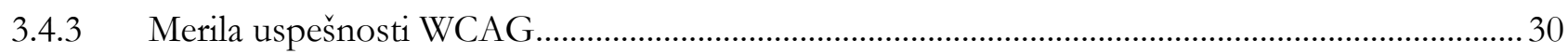

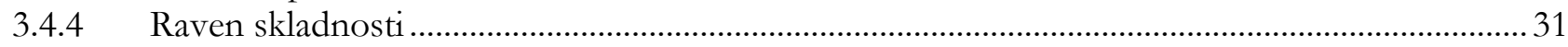

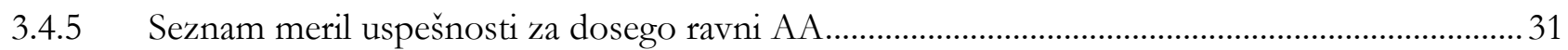

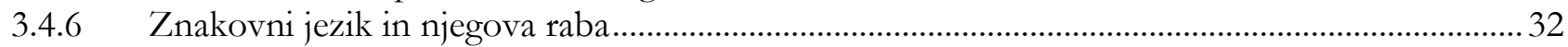

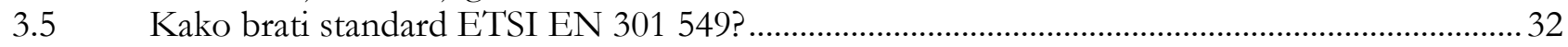




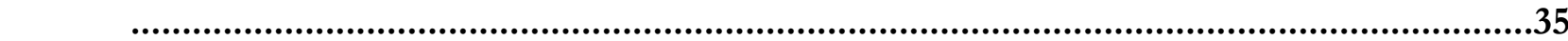

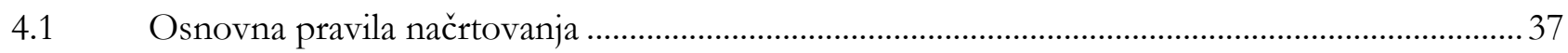

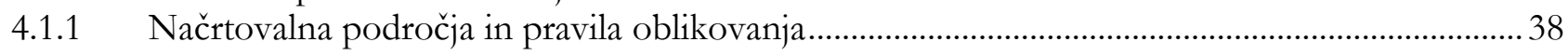

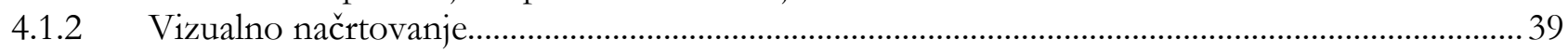

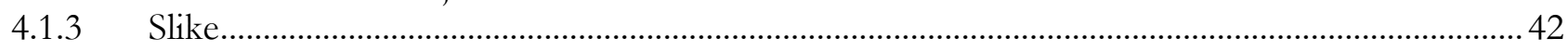

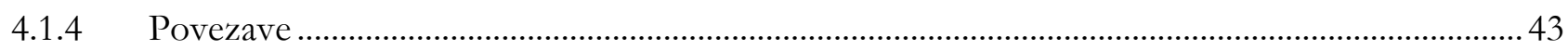

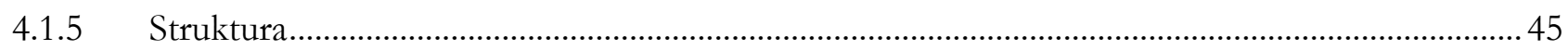

$5 \quad$ Dobri in slabi primeri oblikovanja glede na dostopnost ........................................47

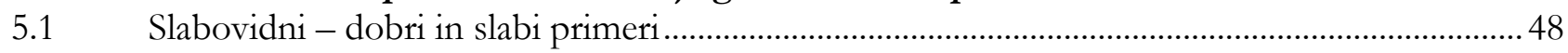

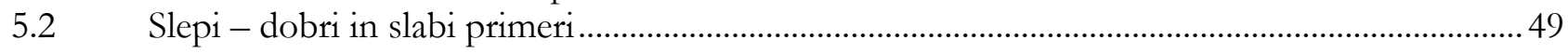

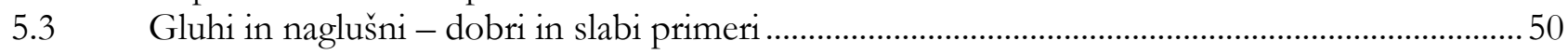

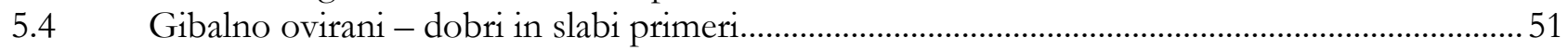

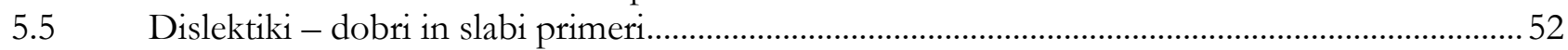

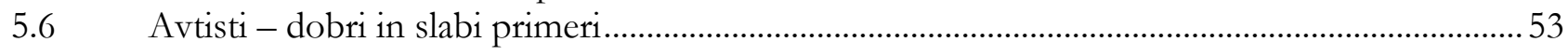

$6 \quad$ Primeri zaznanih neskladnosti in njihova odprava .............................................55

$7 \quad$ Načini ocenjevanja in preverjanja dostopnosti spletnih strani ter aplikacij ..................59

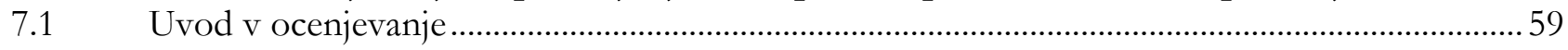

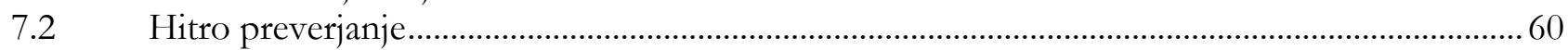

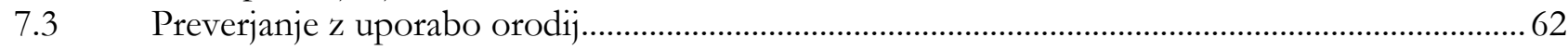

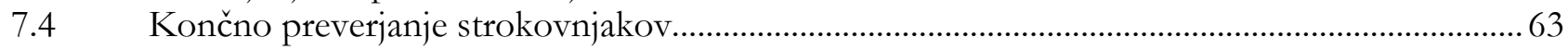

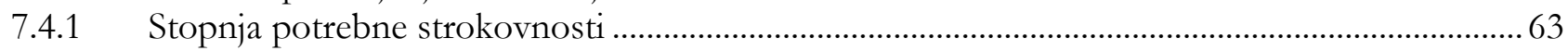

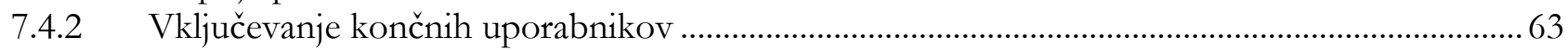

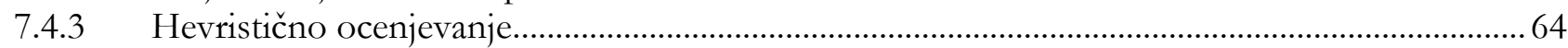

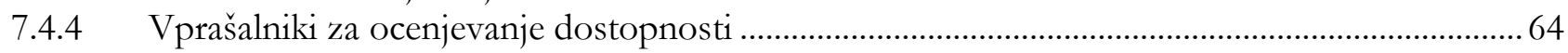

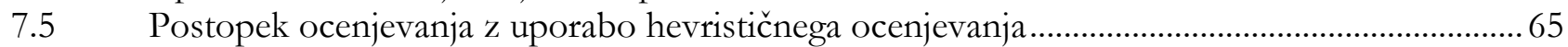

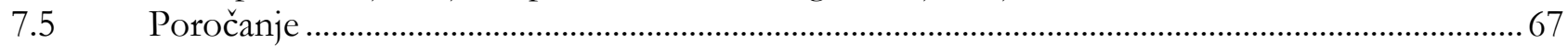

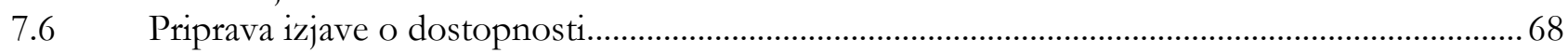

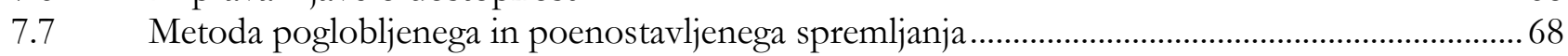

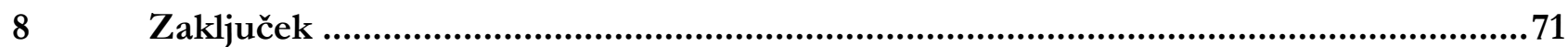

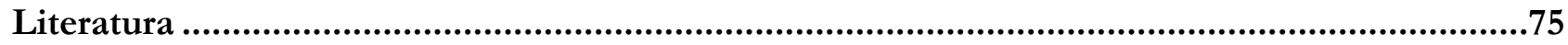




\section{Predgovor}

Monografija Dostopnost digitalnih produktov za use je nastala kot del projekta RSDO - Razvoj slovenščine v digitalnem okolju. Cilj projekta, ki se je odvijal od leta 2020 do 2021, je bil zadovoljiti potrebe po računalniških izdelkih in storitvah s področja jezikovnih tehnologij za slovenski jezik v raziskovalnih organizacijah, podjetjih in širši javnosti.

Končni izdelki projekta, ki bodo prosto na razpolago, bodo na uporabniško prijazen način pomagali pri sporazumevanju, sodelovanju, poslovanju, izmenjavi znanja in udeleževanju invalidov $\mathrm{v}$ družabnih in političnih razpravah ter prispevali $\mathrm{k}$ premagovanju jezikovnih meja.

V okviru te monografije smo želeli javnosti, raziskovalcem in študentom predstaviti značilnosti, zahteve in potrebe oseb z različnimi oblikami oviranosti ter osnove in pravila oblikovanja ter ocenjevanja spletnih strani, mobilnih aplikacij in produktov. Pripravili smo tudi osnovo za ustrezno in dostopno oblikovanje računalniških izdelkov ter storitev.

Z monografijo smo želeli tudi pokazati, da zagotavljanje dostopnosti ne more biti zgolj minimalna korekcija spletišča ali mobilne aplikacije, ki se naloži programerju, ker ta večinoma ni usposobljen, da bi zagotovil skladnost za vsa merila uspešnosti. Zagotavljanje kontrasta in dodajanje besedil $\mathrm{k}$ slikam, kar sicer res lahko naredi tudi programer, namreč še ne pomenita, da smo s tem uspešno uredili dostopnost. Potrebno je veliko več. In sicer 
sodelovanje urednikov, oblikovalcev, urejevalcev in vnašalcev informacij ter predvsem konkretna analiza in širše poznavanje potreb oseb z različnimi oblikami oviranosti.

Monografija predvsem izpostavlja načine za oblikovanje po načelih dostopnosti ob pomoči smernic za dostopnost spletnih vsebin - WCAG (angl. Web Content Accessibility Guidelines). Dodatno so prikazani tudi načini, kako lahko hitro in učinkovito testiramo glede na dostopnost ter kako naj poročamo o izvedenih rešitvah.

Navodila v tej monografiji so sicer namenjena organom javnega sektorja že po zakonih, vendar so lahko v pomoč tudi podjetjem, ki želijo nekaj narediti tudi za širšo populacijo svojih uporabnikov.

Projekt RSDO financirata Ministrstvo za kulturo Republike Slovenije in Evropski sklad za regionalni razvoj. Sofinanciranje monografije je prevzela Univerza v Mariboru, Fakulteta za elektrotehniko, računalništvo in informatiko. 


\section{Uvod}

\subsection{Vzpon informacijske in komunikacijske tehnologije}

$\mathrm{V}$ zadnjem času se srečujemo $\mathrm{z}$ izjemno razširitvijo uporabe informacijske in komunikacijske tehnologije (IKT) v vsakdanjem življenju. Vsaka nova tehnologija, ki se pojavi na tržišču, doseže večino uporabnikov v vsakokrat krajšem času. Če je bilo za radio potrebnih vsaj 10 let, za TV dve leti manj, za DVD samo šest let, so mobilni telefoni potrebovali samo nekaj let [Carey, 2010]. Vse to kaže na to, da smo ljudje zelo hitro razumeli in sprejeli digitalne produkte $\mathrm{v}$ svoje vsakdanje življenje. Uporaba IKT po drugi strani daje izjemne priložnosti in izzive ljudem, ki so bili še do nedavnega zelo zapostavljeni in na robu socialnega ter družbenega življenja. Govorimo o osebah z različnimi oblikami oviranosti, kot so invalidi in starejši. Zanje je danes IKT novo okno v svet, kjer se lahko predstavijo v najboljši luči, svoje oviranosti skoraj v celoti odpravijo in v ospredje postavijo svoje želje, cilje ter sposobnosti.

Ker potrebujejo osebe z različnimi oblikami oviranosti različne pristope do IKT, jim je treba omogočiti ustrezni in prilagojeni dostop. Na primer, gluha oseba ne more poslušati zvočnih posnetkov, slepa oseba ne more gledati slik in gibalno ovirani ne more uporabljati tipkovnice. Skoraj vsaka skupina ima svoje značilnosti, potrebe in zahteve po dostopnosti, zato je treba razmišljati ne samo o klasični dostopnosti, kot je dostopnost do gradbenih objektov in javnega prometa s premagovanjem fizičnih ovir, temveč tudi o digitalni dostopnosti [Lazar, 2015] kot, na primer, o dostopnosti do spletišč ter klasičnih računalniških in mobilnih aplikacij. 


\subsection{Statistični podatki}

O tem, kako pomembno je ponuditi digitalno dostopnost, govorijo tudi podatki o številu oseb, ki to potrebujejo. Svetovna zdravstvena organizacija (angl. World Health Organisation - WHO) [WHO, 2011] v svojih poročilih ugotavlja, da je na svetu kar milijarda oseb z različnimi oblikami oviranosti, kar predstavlja kar $15 \%$ celotne svetovne populacije. WHO prav tako ugotavlja, da kar $80 \%$ teh oseb živi v nerazvitih državah, pri čemer ponekod celo 1 oseba z različnimi oblikami oviranosti na 3 »neovirane« osebe. In številka vztrajno raste. Še posebej zaradi dejstva, da se svetovno prebivalstvo vztrajno stara, s tem pa se povečuje tudi število oseb z različnimi oviranostmi, saj s starostjo vse bolj začnejo pešati predvsem vid in sluh ter motorika [Damron-Rodriguez, 1995]. Poleg staranja prebivalstva število narašča tudi zaradi vse večje ozaveščenosti o pridobitvah, ki olajšujejo življenje oseb z različnimi oblikami oviranosti v socialnem in družbenem okolju. Če so se ljudje še do nedavnega bali tega, da bi se opredelili za »invalide«, se danes zaradi teh olajšav in pridobitev opredeljujejo z veliko bolj pozitivnim pristopom. Prav tako se tudi socialni sistem držav trudi s humanim zbiranjem informacij o osebah z različnimi oviranostmi, zato da se jim učinkoviteje pomaga $\mathrm{v}$ družbenem in delovnem okolju.

V Evropi je po EUROSTAT [Eurostat, 2017] okrog 80 milijonov oseb z različnimi oblikami oviranosti. Od celotne populacije je v povprečju kar $25 \%$ ljudi, starejših od 16 let, ki so prijavljeni kot osebe z dolgotrajnimi različnimi oblikami oviranosti (Slika 1). Najvišjo stopnjo ima Latvija 41 \%, ki ji na drugem mestu sledi Slovenija s $36 \%$. Najnižjo stopnjo za zdaj zabeleži Malta, kjer bi naj bilo samo $12 \%$ oseb z različnimi oblikami oviranosti. Dodatni podatki kažejo, da kar $75 \%$ oseb s težjimi različnimi oblikami oviranosti ne more dobiti službe v običajnem delovnem okolju, saj jih delodajalci pogosto odklanjajo in jih ne želijo vključiti v svoj delovni proces. V povprečju se tudi ugotavlja, da $30,7 \%$ oseb z različnimi oblikami oviranosti med 15 in 34 leti nima službe ali nima izobrazbe.

Po poročilih Inclusive City Makerja [Inclusive City Maker, 2019] naj bi bilo med prebivalstvom največ slepih in slabovidnih (okrog $17 \%$ ), sledijo jim osebe z okvaro sluha (okrog $6 \%$ ), nato osebe z intelektualnimi oviranostmi (okrog 2,6\%) in kot četrta največja skupina gibalno ovirani (okrog $1 \%$ ). 


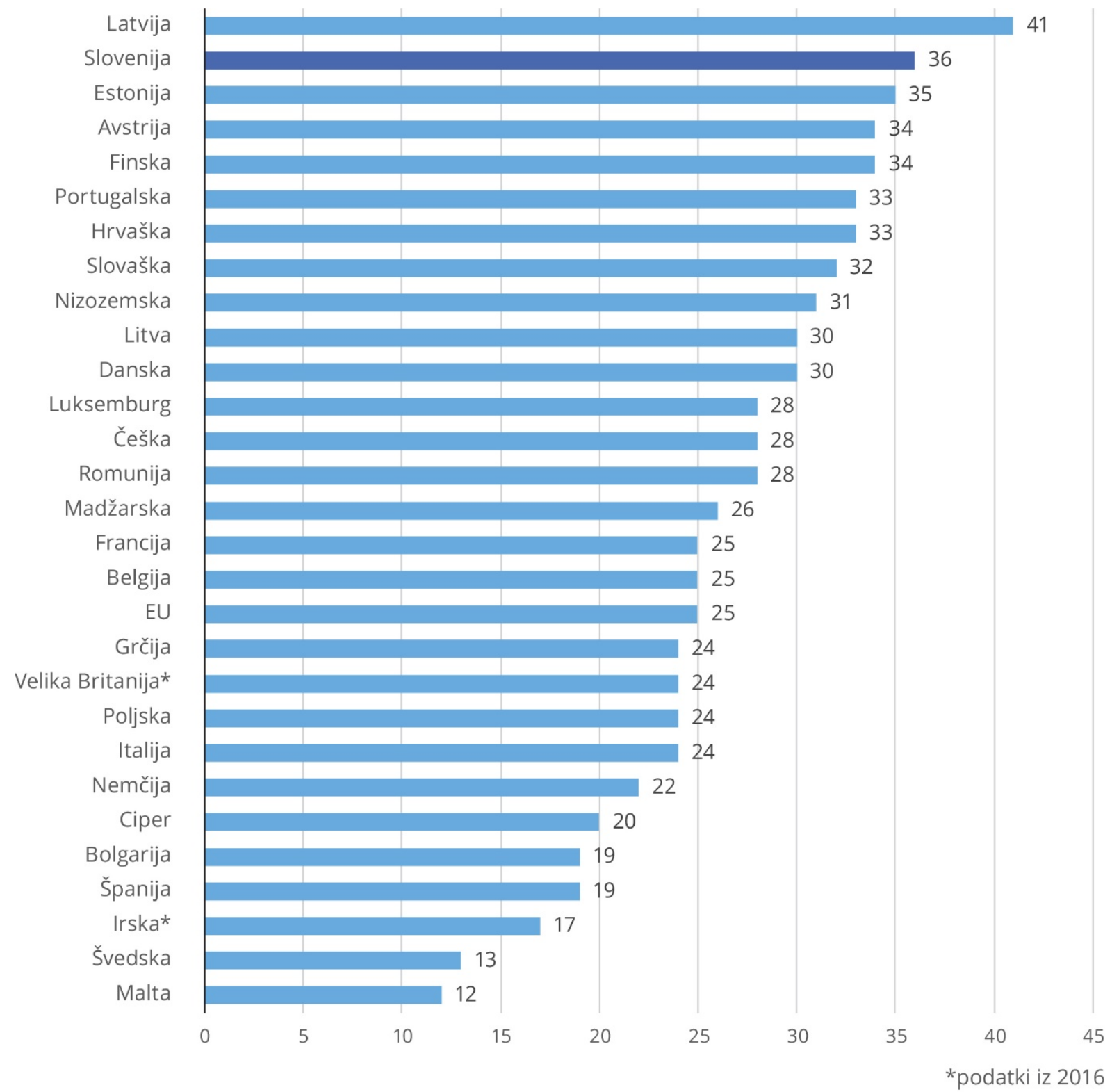

Slika 1: Delež oseb z različnimi oblikami oviranosti, starejših od 16 let, v Evropi po državah [Eurostat, 2017]

Iz teh številk lahko sklepamo, da je delež oseb z različnimi oblikami oviranosti v prebivalstvu tako velik, da jih nikakor ne smemo zanemarjati ali zmanjševati njihovega vpliva. Za državni sistem je vsekakor primerneje, da se tako veliko število ljudi enakopravneje vključi v socialno in delovno okolje, kot pa da so odrinjeni na stran in prepuščeni samemu sebi ter dobri volji drugih ljudi, ki skrbijo zanje. 


\subsection{Ovire}

Za vse osebe z različnimi oblikami oviranosti je torej osnovni cilj, da se vključijo v vsakdanje življenje in so pri svojem delu lahko samostojne ter enakopravne do vseh ostalih udeležencev [World Bank, 2019]. Žal pa je iz različnih študij razvidno, da nimajo povsod enakih možnosti za izobraževanje in zaposlitev [Eurostat, 2015]. Še vedno je marsikje v Evropi razviden prevelikdelež nezaposlenih oseb z različnimi oblikami oviranosti, ki imajo tudi manjše prihodke kot ostalo delovno prebivalstvo.

To je posledica pomanjkanja dostopnih digitalnih rešitev in storitev, ki bi omogočale lažjo vključenost $\mathrm{v}$ delovno okolje. Na voljo je sicer veliko različnih digitalnih produktov, vendar je večina bila načrtovana z mislijo na točno določeno skupino ljudi, ki so bolj digitalno pismeni. Šele v zadnjem času se velika računalniška podjetja zavedajo pomena in vloge oseb z različnimi oblikami oviranosti, zato so začela vgrajevati v svoje digitalne produkte tudi rešitve zanje, vendar so te še vedno v povojih in niso povsod dosegljive. Že uporaba pametnega telefona za starejše lahko predstavlja hudo veliko oviro, na primer, zaradi množice funkcij, nehotenih pritiskov na zaslon, majhnosti črk in ikon ter slabega zvoka.

$S$ pojavom interneta, spleta in informativnih mobilnih aplikacij so se pojavile tudi informativne aplikacije, kot so, na primer, kot so spletni časopisi, spletni oglasi in informativni video portali. Kljub poplavi teh tehnoloških medijev pa je še vedno razvidno še vedno pomanjkanje posluha za predstavitev informacij $\mathrm{v}$ prilagojeni in dostopni obliki. Osebe z različnimi oblikami oviranosti pogosto sploh ne morejo ustrezno zajeti in razumeti informacije [Adam, 2006]. Na primer, slepi ne morejo navigirati po časopisu, saj so navigacijske tipke oblikovane v obliki slik, in gluhi, za katere je prvi znakovni jezik, imajo težave z razumevanjem pisnega besedila. Obstajajo tudi druge vrste ovir, ki bi jih prav tako morali upoštevati pri oblikovanju digitalnih informacij in aplikacij, ampak jih razvojniki večinoma ne, saj so osredotočeni predvsem na večjo, splošno populacijo. Seveda to pomeni diskriminacijo oseb z različnimi oblikami oviranosti, kar pa je nedopustno ravnanje, še posebej, če vemo, da je teh oseb zelo veliko.

Najpogostejši razlog, da razvojniki ne upoštevajo načel dostopnosti, je v tem, da zaradi sedanjega izobraževalnega sistema, ki ne vključuje pravil in navodil za izvedbo digitalne dostopnosti, niso dovolj poučeni in usposobljeni za razvoj dostopnih rešitev. Poleg tega je še vedno razvidno pomanjkanje razvojnih orodij ter načrtovalnih in programskih virov za razvoj dostopnih rešitev. 
Da bi ta problem premostili, so začele nekatere platforme za razvoj spletišč, kot je WordPress, Drupal ali Joomla! [Riley-Huff, 2012], v zadnjem času nuditi tudi ustrezne predloge, ki vključujejo vse zahteve za oblikovanje dostopnih spletnih strani. Kljub temu je potrebno še vedno dobro poznavanje vseh zahtev za oblikovanje dostopnih spletnih strani in aplikacij. Predvsem je treba poznati razlike med posameznimi merili uspešnosti in ravnmi dostopnosti, ki jih določajo ustrezni standardi. Glede na ustrezne zahteve standarda in ciljno populacijo lahko namreč oblikujemo samo nekaj potrebnih rešitev in ne popolnoma vseh.

Podatki iz različnih raziskav kažejo, da tudi digitalna dostopnost še do nedavnega ni bila urejena tako, kot bi bilo treba, saj so podatki še v letu 2019 pokazali velike pomanjkljivosti. Organizacija WebAIM je, na primer, v začetku leta 2019 izvedla ocenjevanje dostopnosti enega milijona spletnih strani s svojim testnim orodjem. Ugotovili so, da je kar 98,1\% spletnih strani pokazalo določene napake glede dostopnosti [WebAIM, 2020].

$\mathrm{V}$ isti raziskavi so ugotovili, da je bilo na milijon spletnih straneh kar 60,9\% različnih napak glede na dostopnost (Slika 2). Najpogostejša napaka je bila premajhen kontrast besedila (86,3\%), kar pomeni, da imajo slabovidni ob tem velike težave pri razločevanju. Naslednje zelo pogoste napake so bile manjkajoče besedilo za ALT-značko za slike, ki so na spletni strani (66\%), ter prazne povezave (59,9\%), ki ne kažejo nikamor oziroma kažejo na spletne strani, ki ne obstajajo več. Ostale pogoste napake so bile pomanjkanje besedila za vhodna dialogna okna (53,8 \%), prazni gumbi za izbiro $(28,7 \%)$ ter manjkajoči podatek o jeziku spletne strani (28\%).

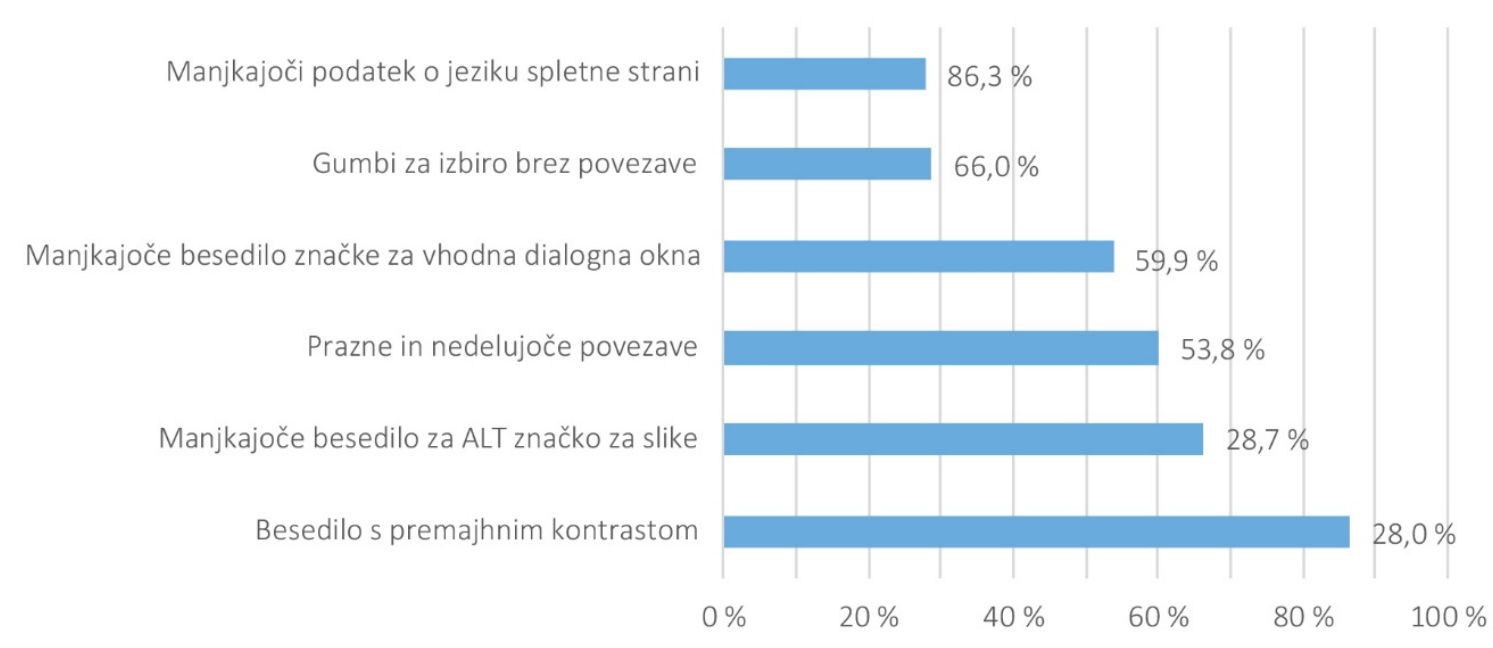

Slika 2: Najpogostejši vzroki za napake pri dostopnosti spletnih strani [WebAIM, 2020] 
Druge raziskave, kot je bila, na primer, Flash Eurobarometer, tudi kažejo, da so leta 2012 na vzorcu 1.000 oseb z različnimi oblikami oviranosti iz Slovenije ugotovili, da se jih kar $69 \%$ strinja, da ovire pri dostopnosti za osebe $z$ različnimi oblikami oviranosti otežujejo obiskovanje šole, službe, udeležbo na volitvah in/ali prosto gibanje, odhod na dopust, kar je malenkost večji delež kot na ravni celotnega EU (EU = 66 \%) [Tabaj, 2014].

\subsection{Mogoče rešitve}

Iz navedenega sledi, da je za razvoj dostopnih digitalnih produktov treba poleg standardov urediti tudi podporo državnih institucij in velikih podjetij ter izobraževalnih institucij, ki bi ustrezno usposabljaleprimerne kadre. Državne institucije se sicer zavedajo problematike in iščejo mogoče rešitve podpore $\mathrm{v}$ čim večji meri, vendar je takšen proces običajno zamuden in težaven. $\mathrm{V}$ tem primeru je dobrodošla pomoč velikih podjetij, kot so Microsoft in Apple ter proizvajalci mobilnih produktov, ki vanje v vse večji meri vključujejo tudi rešitve za dostopnost [Kulkarni, 2019].

Evropska komisija je za reševanje problematike dostopnosti sprejela Evropski akt o dostopnosti, ki zahteva, da so produkti in storitve prilagojeni osebam z različnimi oblikami oviranosti. Na njegovi podlagi se potem sprejemajo ostali podzakonski predpisi, ki jih je oziroma jih bo treba upoštevati. Še posebej je pomembna ureditev dostopnosti do spletnih strani in aplikacij $\mathrm{v}$ javnem sektorju, ki je prav tako pokrita $\mathrm{z}$ različnimi zakoni in predpisi.

Pomemben dokument v smeri izboljšanja je tudi Agenda za trajnostni razvoj do leta 2030 iz leta 2015 [UNO, 2020], ki jo je sprejelo 193 članic Združenih narodov. V njej je jasno navedeno, da oviranost ne more več biti razlog ali merilo za pomanjkanje dostopa do digitalnih produktov in uresničevanja človekovih pravic. Okvir trajnostnega razvoja v tej agendi vključuje sedem ciljev, ki se izrecno nanašajo na osebe z različnimi oblikami oviranosti, in šest nadaljnjih ciljev za osebe v ranljivih situacijah. Njeni cilji obravnavajo ključna razvojna področja, kot so izobraževanje, zaposlovanje in dostojno delo, socialna zaščita, odpornost na nesreče in njihova ublažitev, sanitarni prevozi, prevoz in nediskriminacija. 


\subsection{Pravni okvir}

Evropska Direktiva o dostopnosti spletišč in mobilnih aplikacij organov javnega sektorja [EU, 2016], ki je bila osnova za slovenski zakon (Zakon o dostopnosti spletišč in mobilnih aplikacij [RS, 2018]), določa, da morajo organi javnega sektorja omogočiti dostopnost tako, da bodo spletišča in mobilne aplikacije skladni z zahtevami te direktive. Organi javnega sektorja morajo nuditi izjavo o dostopnosti, mehanizem za zagotavljanje povratnih informacij $\mathrm{v}$ primeru, ko spletišča ali mobilne aplikacije ne spoštujejo zahtev o dostopnosti, ter povezavo do izvršilnega postopka. V praksi pomeni ta direktiva, da morajo biti nove spletne strani javnih organov dostopne od 23. septembra 2020 (Tabela 1).

Tabela 1: Časovni načrt implementacije dostopnosti po direktivi EU

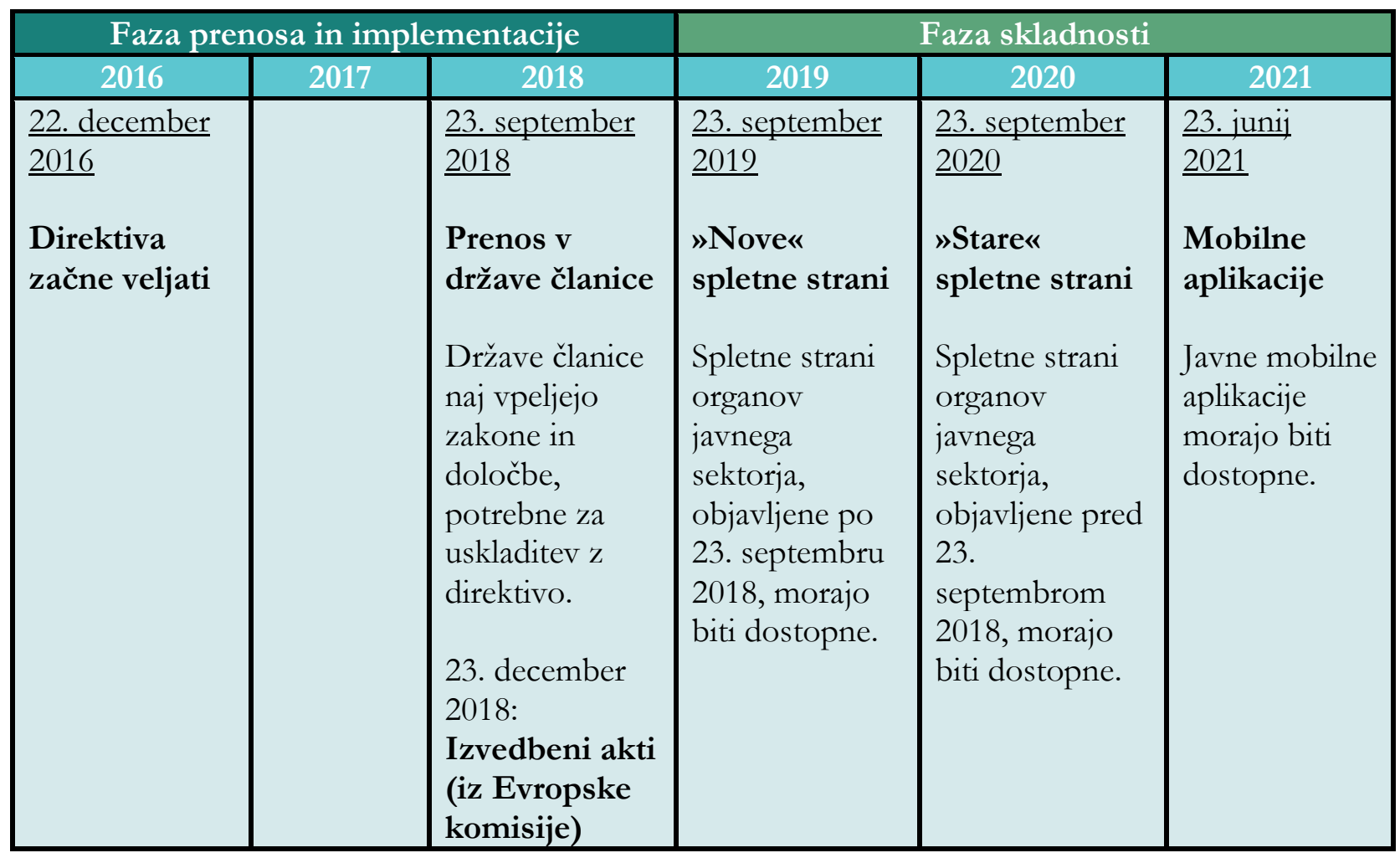

Druga direktiva, ki pomeni enega najpomembnejših dosežkov Evropske skupnosti na področju izboljšanja statusa oseb $\mathrm{z}$ različnimi oblikami oviranosti $\mathrm{v}$ Evropi in za uresničevanje določil Konvencije Združenih narodov (angl. United Nations Organisation) [UNO, 2006], je zagotovo evropska Direktiva o zahtevah glede dostopnosti za proizvode in storitve [EU, 2019]. Po tem datumu se začenja prehodno triletno obdobje (do 28. junija 2022), v katerem morajo države članice sprejeti in objaviti zakone ter druge predpise, potrebne za uskladitev s to direktivo. Vsi ukrepi, ki so določeni v tej direktivi o 
dostopnosti, pa se bodo morali uporabljati od 28. junija 2025. Direktiva predstavlja zaključno točko po vztrajnem, desetletnem lobiranju in trudu invalidskih organizacij po vsej Evropi za izboljšanje stanja oseb z različnimi oblikami oviranosti $\mathrm{v}$ domačem, delovnem in socialnem okolju. Gre za izjemno pomemben korak, ki bo na določenih področjih omogočal ustrezno dostopnost in uporabo proizvodov ter storitev glede na potrebe in zahteve oseb z različnimi oblikami oviranosti.

Tretja direktiva, ki določa dostopnost, je evropska Direktiva o univerzalni storitvi in pravicah uporabnikov $\mathrm{v}$ zvezi z elektronskimi komunikacijskimi omrežji in storitvami (Direktiva o univerzalnih storitvah) [EU, 2002]. Del te direktive je tudi enotna telefonska številka za klic v sili v EU 112, ki mora biti brezplačna. Dostopna mora biti tako s stacionarnega kot tudi z mobilnega telefona ne glede na to, ali je oseba priključena na omrežje telekomunikacijskega ponudnika ali ne.

Četrta evropska direktiva, kjer se omenja dostopnost, je evropska Direktiva o avdiovizualnih medijskih storitvah [EU, 2018]. Do konca leta 2020 so države članice dolžne izpolniti zahteve te direktive. Ta je zanimiva tudi za osebe z različnimi oblikami oviranosti, saj vključuje obvezne zahteve za dostopnost v svojem 7. členu. Ta zahteva, da morajo ponudniki avdiovizualnih storitev nuditi sprotno in progresivno večjo dostopnost za osebe z različnimi oblikami oviranosti. To pomeni, da je treba urediti več podnapisov in video posnetkov tolmača znakovnega jezika za gluhe in naglušne, več zvočnih zapisov ali govorjenih podnapisov za slepe in slabovidne $\mathrm{v}$ televizijskih programih, serijah, filmih, novicah in $\mathrm{v}$ dokumentarnih oddajah.

S tem se sledi tudi Konvenciji Združenih narodov o pravicah invalidov in drugim pravnim podlagam, ki določajo, da so uporabniki z različnimi oblikami oviranosti enakopravni z drugimi uporabniki. To je tudi določeno v Ustavi Republike Slovenije [RS, 1991] ter v Zakonu o izenačevanju možnosti invalidov [RS, 2010].

Ena od pomembnih aktivnosti za izboljšanje stanja je tudi ustrezno usposabljanje razvijalcev in ocenjevalcev, ki se bodo ukvarjali z dostopnostjo na posameznih področjih. Pričujoča monografija predstavlja enega od ukrepov, ki bodo prispevali k ustreznemu usposabljanju. Rezultati tega bodo morali biti razvidni v obliki novih, sodobnih in dostopnih proizvodov ter storitev. 
V praksi bo ocenjevanje potekalo tako, da se bodo upoštevale zahteve iz ustreznih standardov. Pri dostopnosti spletišč in mobilnih aplikacij se bo v praksi uporabljal evropski standard ETSI EN 301549 - Zahteve za dostopnost izdelkov in storitev IKT, ki je preveden tudi v slovenski jezik [ETSI, 2016]. Ta dokument določa praktične in merljive zahteve za funkcijsko dostopnost, ki upoštevajo zahteve in potrebe oseb $\mathrm{z}$ različnimi oblikami oviranosti ter so primerne za vse proizvode in storitve informacijske in komunikacijske tehnologije. Standard EN 301549 se naslanja predvsem na Smernice za dostopnost spletnih vsebin (WCAG 2.1) [W3C, 2018].

Dodatno je pri predpisih v Sloveniji treba upoštevati tudi Zakon o uporabi slovenskega znakovnega jezika iz leta 2002 [RS, 2002], ki določa pravice gluhih oseb pri uporabi slovenskega znakovnega jezika ter njihovo pravico do informiranja v njim prilagojenih tehnikah (Tabela 1).

Pri vseh zakonih in predpisih je enotno to, da morajo spletišča, mobilne aplikacije, proizvodi izpolnjevati osnovne zahteve o dostopnosti, kot so predstavitev informacij v ustrezno prilagojeni obliki, ki jo lahko zaznajo, ter ustrezno prilagojeni, razumljivi uporabniški vmesniki in navigacija. Poleg tega je treba upoštevati tudi možnost, da bodo uporabniki uporabljali dodatna, računalniško podprta orodja, kot je samodejni bralnik zaslona za slepe ali sistem za samodejno zaznavanje govora in izpis podnapisov. Ob tem je treba že v razvoju uporabniških vmesnikov upoštevati to možnost in predvsem na koncu razvoja izvesti obvezno ocenjevanje povezljivosti s temi orodji.

Če se zgodi, da digitalni produkti niso ustrezno dostopni, imajo osebe z različnimi oblikami oviranosti zdaj priložnost, da prek teh zakonskih predpisov uveljavljajo svoje pravice do dostopnosti. Pri tem morajo imeti najprej na voljo orodja za pošiljanje povratne informacije o nedostopnosti ter ne nazadnje pomoč izvršilnega postopka, ki lahko vodi tudi do uveljavljanje pravic na sodišču. Primer tega je slovenska spletna stran eUprave, na kateri je uradna izjava o dostopnosti skupaj z informacijo o tem, na koga se lahko obrnejo prizadeti v primeru nedostopnosti.

Pri tem je treba upoštevati, da obstaja tudi zakonski člen, ki dopušča neizvedbo dostopnosti, če gre za nesorazmerno breme. To v praksi pomeni, da za manjšo javno ustanovo z manjšim finančnim okvirom ni obvezno, da izvede dostopnost digitalnih produktov, če bi to presegalo njene finančne zmožnosti in koristi v primerjavi z ocenjenimi koristmi za osebe $z$ različnimi oblikami oviranosti. To finančno nezmožnost je treba tudi ustrezno dokazati, saj bi se sicer lahko zgodilo, da bi večina javnih ustanov in podjetij 
začela posegati po tej olajšavi. To lahko ustanova pojasni v svoji spletni izjavi o dostopnosti, kjer opiše, katerih delov zahtev o dostopnosti ji ni uspelo uresničiti, in po potrebi predstavi tudi druge, alternativne možnosti. Izjava o dostopnosti mora biti $\mathrm{v}$ skladu z Izvedbenim sklepom o določitvi vzorca izjave o dostopnosti (Tabela 1).

Tabela 2: Pravne podlage in obveznosti za dostopnost spletišč in mobilnih aplikacij

\begin{tabular}{|l|c|}
\hline Direktiva o dostopnosti spletišč in mobilnih aplikacij organov javnega sektorja & $2018 \mathrm{EU}$ \\
\hline Izvedbeni sklep o harmoniziranem standardu za spletišča in mobilne aplikacije & $2018 \mathrm{EU}$ \\
\hline Izvedbeni sklep o določitvi metodologije spremljanja in ureditev poročanja držav članic & $2018 \mathrm{EU}$ \\
\hline Izvedbeni sklep o določitvi vzorca izjave o dostopnosti & $2018 \mathrm{EU}$ \\
\hline Zakon o dostopnosti spletišč in mobilnih aplikacij & $2018 \mathrm{SLO}$ \\
\hline Pravilnik o določitvi vzorca izjave o dostopnosti & $2019 \mathrm{SLO}$ \\
\hline ETSI EN 301 549 - Zahteve za dostopnost izdelkov in storitev IKT & $2019 \mathrm{EU}$ \\
\hline Zakon o izenačevanju možnosti invalidov & $2010 \mathrm{SLO}$ \\
\hline Zakon o uporabi slovenskega znakovnega jezika & $2002 \mathrm{SLO}$ \\
\hline Smernice za dostopnost spletnih vsebin (WCAG 2.1) & $2018 \mathrm{~W}$ 3C \\
\hline
\end{tabular}




\section{Značilnosti in zahteve oseb $\mathrm{z}$ različnimi oblikami oviranost}

Predpogoj za učinkovito oblikovanje in ocenjevanje digitalnih produktov za osebe z različnimi oblikami oviranosti je dobro poznavanje njihovih značilnosti in zahtev. Veliko ljudi, na primer, meni, da bi vsaka gluha oseba morala znati brati, zato naj ne bi potrebovala znakovnega jezika. Žal ni tako, saj je za gluhe osebe znakovni jezik prvi jezik, slovenski pisni jezik pa drugi jezik. Podobno kot slišečemu pomeni tuji jezik. Iz tega razloga je treba zagotoviti, da se strokovnjak, ki se odloča za oblikovanje in ocenjevanje dostopnosti, najprej dobro seznani z informacijami o kategorijah oseb z različnimi oblikami oviranosti, njihovimi značilnostmi in zahtevami ter potrebami, kar je tudi tematika tega poglavja.

\subsection{Kategorije oseb z različnimi oblikami oviranosti}

Za osebe z različnimi oblikami oviranosti v Sloveniji ni poenotene kategorizacije. Različni avtorji uporabljajo različne opredelitve. Največkrat uporabljena je tista, ki so jo opredelili Dimic, Blažič, in Kavkler [Dimic, Blažič, \& Kavkler, 2010] na podlagi zakona o usmerjanju otrok s posebnimi potrebami (Zakon o usmerjanju otrok s posebnimi potrebami) [RS, 2011] in našteva naslednjih devet skupin:

- osebe z motnjami v duševnem razvoju,

- slepe in slabovidne osebe,

- gluhe in naglušne osebe, 
- osebe z govorno-jezikovnimi motnjami,

- gibalno ovirane osebe,

- dolgotrajno bolne osebe,

- osebe s primanjkljaji na posameznih področjih učenja,

- osebe s čustvenimi in z vedenjskimi motnjami,

- osebe z motnjami avtističnega spektra.

Med temi niso omenjeni starejši kot posebna kategorija, vendar se s starostjo začenjajo različne oblike oviranosti, ki se večinoma pojavijo po 65. letu. Te so [Griffith, 2010]:

- gibalna oviranost (težave z nogami, artritis, padci),

- težave v kognitivnem funkcioniranju (dementnost),

- slabovidnost,

- naglušnost.

Poleg teh oblik oviranosti se pri starejših pojavljajo še tudi srčne, arterijske in pljučne bolezni, ki vplivajo na njihovo sposobnost gibanja, hitrost premikanja telesa in splošno telesno kondicijo.

V okviru slovenskega Zakona o dostopnosti spletišč in mobilnih aplikacij se za osnovo in preverjanje uporablja standard ETSI EN 301549 [ETSI, 2016], ki pa določa natančnejšo kategorizacijo oviranosti z razdelitvijo funkcijskih lastnosti oseb. Standard tako našteva deset kategorij, iz katerih so nato tudi izpeljane posamezne zahteve za digitalne produkte, ki jih treba upoštevati pri njihovem razvoju in ocenjevanju.

Te funkcijske lastnosti, navedene v standardu ETSI EN 301549 [ETSI, 2016], so:

- uporaba brez vida,

- uporaba z omejenim vidom,

- uporaba brez zaznavanja barv,

- uporaba brez sluha,

- uporaba z omejenim sluhom,

- uporaba brez sposobnosti govora,

- uporaba z omejeno gibalnostjo in močjo,

- uporaba z omejenim sežajem, 
- zmanjšanje svetlobno občutljivih prožilcev (napad svetlobne preobčutljivosti),

- uporaba z zmanjšanimi kognitivnimi sposobnostmi.

Glede na omenjene funkcionalne omejitve so v standardu navedeni primeri upravljanj in možnosti, ki lahko rešujejo različne funkcionalne omejitve - eno ali več hkrati. Teh deset funkcionalnih omejitev mora dobro poznati vsak razvijalec in kasneje tudi programer, da lahko zadosti zakonskim zahtevam po dostopnosti.

Spoznavanje in ugotavljanje zahtev ter potreb sta tako eni prvih aktivnosti, s katerimi se razvijalci in programerji srečujejo pri razvoju dostopnih rešitev, vendar teh deset kategorij lahko smiselno skrčimo v štiri glavne (Slika 1):

- gibalno ovirane osebe,

- slepe in slabovidne osebe,

- gluhe in naglušne osebe,

- osebe s težavami v kognitivnem funkcioniranju.

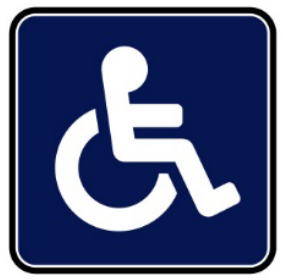

Gibalno ovirane osebe

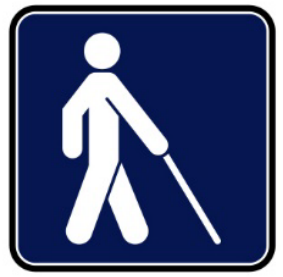

Slepe in slabovidne oseb

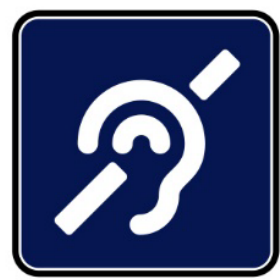

Gluhe in naglušne osebe

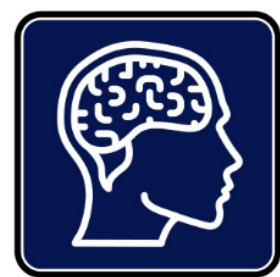

Osebe s težavami v kognitivnem funkcioniranju

Slika 3: Kategorije oseb z različnimi oblikami oviranosti

Za osebe iz vseh omenjenih kategorij se v slovenski zakonodaji sicer najpogosteje uporablja beseda »invalid «. Za to besedo najdemo, med drugim, v slovenski zakonodaji naslednjo terminologijo, in sicer:

- Zakon o izenačevanju možnosti invalidov, 3. člen [RS, 2010] »Invalidi so osebe z dolgotrajnimi telesnimi, duševnimi in senzoričnimi okvarami ter motnjami $\mathrm{v}$ duševnem razvoju, ki jih $\mathrm{v}$ povezavi $\mathrm{z}$ različnimi ovirami lahko omejujejo pri tem, da bi enako kot drugi polno in učinkovito sodelovali v družbi.« 
Obstaja veliko različnih terminov za opis oseb $z$ različnimi oblikami oviranosti. Mednarodna klasifikacija funkcioniranja, invalidnosti in zdravja organizacije WHO [WHO, 2001] gleda na invalidnost kot na rezultat vzajemnega sodelovanja družbenega in socialnega okolja ter posameznikovega fizičnega in psihičnega stanja. Ker gre za veliko različnih terminov in načinov njihovega razumevanja $\mathrm{v}$ splošnem kontekstu, je potrebna pazljivost pri njihovi rabi.

V tej monografiji uporabljamo termin osebe $\mathbf{z}$ različnimi oblikami oviranosti, kot se pojavlja tudi v Zakonu o dostopnosti spletišč in mobilnih aplikacij [RS, 2018].

V nadaljevanju natančneje opredeljujemo osnovne značilnosti omenjenih štirih kategorij. Povzete so iz različnih študij in raziskav [Aylward, 1998; Davis, 2017; Ernecl, 2018; Jamnik, 2016; Kobolt, 2015; Puc, 2017; Vovk-Ornik; 2015].

V prilogi [Priloga 6] so kot dodatek $\mathrm{k}$ temu opisu značilnosti navedene še zahteve in potrebe glede na potrebne digitalne pripomočke in ureditev okolja ter glede na načela WCAG - zaznavnost, upravljivost, razumljivost in robustnost.

\subsection{Gibalno ovirani}

Gibalno ovirane osebe oziroma osebe z zmanjšanimi zmožnostmi gibanja imajo prirojene ali pridobljene okvare gibalnega aparata, centralnega ali perifernega živčevja [Horvat, 2013], zato imajo težave pri vključevanju v dejavnosti in sodelovanju ob izvajanju fizičnih aktivnosti.

Glede na gibalno oviranost razlikujemo osebe [Horvat, 2013; Kobolt, 2015]:

$$
\begin{aligned}
& \text { - z lažjo, } \\
& - \text { zmerno, } \\
& - \text { s težjo in } \\
& -\quad \text { težko gibalno oviranostjo. }
\end{aligned}
$$




\subsubsection{Osebe z lažjo gibalno oviranostjo}

Oseba ima težave pri gibanju, ki se kažejo kot nekoliko zmanjšane zmožnosti. Hodi samostojno tudi zunaj zaprtih prostorov; lahko ima težave pri teku in daljši hoji po neravnem terenu ali pri gibanju v skupini oseb; lahko ima slabše ravnotežje in težave pri koordinaciji gibanja; samostojna je pri vseh opravilih, razen pri tistih, ki zahtevajo dobro spretnost rok; lahko ima lažje motnje zaznavanja in občutenja dražljajev ter senzomotorične integracije.

\subsubsection{Osebe z zmerno gibalno oviranostjo}

Oseba ima težave pri gibanju, ki se kažejo kot zmerno zmanjšane zmožnosti gibanja samostojno hodi znotraj zaprtih prostorov ali na krajše razdalje, pogosto je potrebna uporaba pripomočkov za gibanje (posebni čevlji, opornice, ortoze, bergle); lahko ima težave na neravnem terenu in stopnicah, kjer je počasnejša, potrebuje nadzor ali oprijemanje. $\mathrm{Na}$ srednje in večje razdalje uporablja prilagojeno kolo ali voziček za transport ali voziček na ročni pogon ali pomoč in nadzor druge osebe. Spretnost rok je lahko zmerno zmanjšana ali pa je zaradi okvare, delne ali popolne odsotnosti ene roke za funkcijo uporabna le ena roka. Oseba ima lahko zmerne motnje zaznavanja in občutenja dražljajev ter senzomotorične integracije.

\subsubsection{Osebe s težjo gibalno oviranostjo}

Oseba ima težave pri gibanju, ki se kažejo kot zelo zmanjšane zmožnosti gibanja. Lahko stopi na nogi ali s pripomočki hodi na kratki razdalji, vendar hoja ni funkcionalna. Od pripomočkov lahko uporablja opornice in ortoze. Lahko ima težjo motnjo orientacije, ki ji onemogoča samostojno gibanje med prostori. Za večji del gibanja znotraj in zunaj prostorov potrebuje voziček na ročni pogon, elektromotorni voziček ali prilagojeno kolo. Pri tem potrebuje pomoč ali nadzor druge osebe. Hoja po stopnicah ni mogoča. Spretnost ene roke ali obeh je zelo zmanjšana in pomembno ovira izvedbo grobih in finih gibalnih spretnosti rok. Zaradi okvare, delne ali popolne odsotnosti ene roke ali obeh je oseba večinoma odvisna od fizične pomoči druge osebe. Lahko ima težje motnje zaznavanja in občutenja dražljajev ter senzomotorične integracije. Pri dnevnih opravilih potrebuje stalen delni nadzor ali pomoč. 


\subsubsection{Osebe s težko gibalno oviranostjo}

Oseba ima težave pri gibanju, ki se kažejo kot povsem zmanjšane zmožnosti gibanja in povzročajo popolno funkcionalno odvisnost. Samostojno gibanje ni mogoče. Samostojno se lahko giblje samo z elektromotornim vozičkom. Ima malo funkcionalnih gibov rok. Lahko ima zelo hude motnje zaznavanja in občutenja dražljajev, orientacije ter senzomotorične integracije. Pri vseh dnevnih opravilih je odvisna od fizične pomoči druge osebe.

\subsection{Slepi in slabovidni}

Osebe, ki so slepe in slabovidne, imajo okvaro vida, očesa ali vidnega polja [Frey, 2005]. Izguba vida otežuje pridobivanje informacij in socialnih izkušenj. Večina oseb z izgubo vida ima vsaj nekaj uporabnega vida. Tudi tisti, ki so slepi, lahko pogosto ločijo med svetlobo in temo. Sposobnosti in posameznikove potrebe pa se močno razlikujejo med seboj. Blazinice prstov so zanje enako pomembne pri branju, kot so za videče oči. Druga skupina oseb so osebe $z$ barvno slepoto, ki imajo večinoma težave pri zaznavanju zelene in rdeče barve.

Slepi in slabovidni imajo naslednje skupne značilnosti:

- težave pri dojemanju in sprejemanju vizualnih informacij,

- težave pri zaznavanju barv,

- težave pri poslušanju slišnih navodil ob hrupu v okolici,

- $\mathrm{v}$ gneči se orientirajo s poslušanjem dogajanja v okolici, zato slušalke za slepe in slabovidne niso najprimernejše;

- so občutljivi in plašni v neznanem okolju;

- med hojo:

- imajo težave pri hoji in orientaciji, kadar se nahajajo sredi glasne množice ljudi;

- imajo težave pri zaznavanju ovir, ki se nahajajo v višini glave;

- včasih potrebujejo pomoč drugih za lociranje in navigacijo;

- imajo težave pri iskanju in določanju robov pločnikov in vozil;

- od naprav naprav največ uporabljajo:

- brajico z glasovnim izhodom,

- glasovni bralnik zaslona,

- povečevalo. 
Žagar [Žagar, 2012] je opredelil vizualno funkcioniranje oseb z različno stopnjo prizadetosti vida:

- slabovidnost (10-30\% vida),

- težka slabovidnost (5-9,9\% vida),

- slepi z ostankom vida (2-4,9\% vida),

- slepi z minimalnim ostankom vida (projekcija 1,9\% vida),

- popolna slepota in nezaznavanje svetlobe.

\subsubsection{Slabovidne osebe}

Slabovidna oseba ima ostrino vida od 5 do 30 odstotkov ali zoženo vidno polje v vseh meridianih nad 10 do vključno 20 stopinj okrog fiksacijske točke ne glede na ostrino vida [Horvat, 2013; Murn, 2020; Žagar, 2012]. Razlikujemo zmerno slabovidno in težko slabovidno osebo. Zmerno slabovidna oseba ima ostrino vida od 10 do 30 odstotkov, težko slabovidna oseba pa od 5 do manj kot 10 odstotkov ali zoženo vidno polje nad 10 do vključno 20 stopinj okrog fiksacijske točke ne glede na ostrino vida.

\subsubsection{Slepe osebe}

Ločimo različne stopnje slepote glede na ostanke vida:

- Slepa oseba z ostankom vida ima ostrino vida od 2 do manj kot 5 odstotkov ali zoženo vidno polje nad 5 do vključno 10 stopinj okrog fiksacijske točke ne glede na ostrino vida.

- Slepa oseba z minimalnim ostankom vida ima ostrino vida od projekcije svetlobe do manj kot 2 odstotka ali zoženo vidno polje na 5 stopinj ali manj okrog fiksacijske točke ne glede na ostrino vida.

- Popolnoma slepa oseba: dojem negativen ali dojem svetlobe pozitiven $z$ negativno projekcijo. 


\subsubsection{Barvno slepe osebe}

V kategorijo slepih in slabovidnih spadajo tudi barvno slepe osebe. Pri njih je razvidna nezmožnost razlik med nekaterimi ali vsemi tremi osnovnimi barvami (zelena, rdeča in modra). Največ oseb je barvno slepih za zeleno ali rdečo. Pri moških je teh $8 \%$, pri ženskah samo $0,4 \%$. V zelo redkih primerih so osebe slepe tudi za modro barvo [Wong, 2011].

\subsubsection{Fotosenzibilne osebe}

V obdobju uporabe zaslonov in uporabe očal za virtualno resničnost so se kot pomembne izpostavile osebe, ki imajo fotosenzitivno epilepsijo. Ta je sicer zelo redka, vendar so posledice zelo resne in lahko povzročijo hude telesne poškodbe. Zaporedje utripanja in hitrosti utripanja ali ponavljajoči se vzorec in/ali besedila lahko izzove epileptični napad. $\mathrm{Na}$ njegov pojav tako vplivata čas trajanja vizualnih učinkov ter delež vidnega polja, ki ga ti zavzemajo.

\subsection{Gluhi in naglušni}

\subsubsection{Osebe $z$ izgubo sluha}

Pri težavah s sluhom ločimo med gluhoto, naglušnostjo in gluhoslepoto. Gluhe in naglušne osebe za slišečimi zaostajajo $\mathrm{v}$ jezikovnem dojemanju, jezikovni produkciji in govoru [Kesič, 2010]. Izguba sluha se običajno ne porazdeli okrog vseh frekvenc enako, prav tako tudi ne z enako glasnostjo. V starosti so običajno visoke frekvence bolj prizadete kot nizke. Gluhoto in naglušnost razvrščamo glede na izgubo glasnosti $\mathrm{v}$ decibelih ( $\mathrm{v}$ nadaljevanju dB).

WHO [WHO, 2020] je definiral kategorije oseb s prizadetim sluhom in jih razvrstil v naslednje kategorije:

1. blaga izguba sluha $-26-40 \mathrm{~dB}$, kjer osebe slišijo in razumejo od 1 metra dalje. Oseba usvaja govor in jezik ter se sporazumeva po slušni poti; v hrupnem okolju se poslužuje tudi veščine odgledovanja z ustnic.

2. zmerna izguba sluha $-41-60 \mathrm{~dB}$, kjer osebe slišijo in razumejo do 1 metra. Oseba usvaja govor in jezik ter se sporazumeva primarno po slušni pot ob uporabi slušnega pripomočka. 
3. zmerno težka izguba sluha - 61-80 dB, kjer osebe slišijo samo, če se jim glasno govori na uho. Oseba usvaja govor in jezik pretežno po slušni poti z uporabo slušnega pripomočka; pri sporazumevanju potrebuje odgledovanje govora $z$ ustnic, nekateri si pomagajo z znakovnim jezikom.

4. težka izguba sluha skupaj z gluhoto - Od $81 \mathrm{~dB}$ dalje, kjer imajo osebe težave $z$ razumevanjem tudi zelo glasnega govora na uho. Oseba z velikimi težavami usvaja govor z uporabo slušnega pripomočka; pri sporazumevanju potrebuje odgledovanje govora z ustnic. Predvsem popolnoma gluhi pa si pomagajo z znakovnim jezikom.

Naglušne osebe imajo težave pri poslušanju, komunikaciji, orientaciji in vključevanju v družbo. Gluhota pa pomeni najtežjo in popolno izgubo sluha. Osebe morajo uporabljati slušni aparat ali polžev vsadek (kohlearni implant) [Wilson, 1991]. Gluhe in težje naglušne osebe pogosto uporabljajo slovenski znakovni jezik kot prvi jezik.

Za znakovni jezik je značilno, da so znaki multimodalni in sestavljeni iz velikega števila hkratno prikazanih podznakov, ki so lahko manualni (oblika roke, poza in premiki) ter nemanualni (poza glave, izraz na obrazu in poza telesa) [Stokoe, 1960].

Izguba sluha vpliva na različna področja življenja osebe - na sporazumevanje, socializacijo in izobraževanje. Razvoj sluha, govora in načina sporazumevanja je odvisen od pravočasne diagnostike okvare sluha, dodelitve slušnega aparata ali vstavitve polževega vsadka, redne uporabe teh pripomočkov in ustrezne rehabilitacije.

\subsubsection{Osebe z govornimi motnjami}

Nekatere osebe imajo tudi težave pri govorjenju. To so predvsem osebe, ki imajo artikulacijske motnje. Gre za nepravilno, popačeno izgovorjavo posameznih glasov. Njihov govor je zaradi tega slabše razumljiv in pogoste so tudi jezikovne motnje, pri čemer prihaja do napak v strukturi in pomenu stavka. Sem spada tudi jecljanje, ki je lahko tudi težje razumljivo.

Gluhi, naglušni in gluhoslepi imajo predvsem naslednje skupne značilnosti:

- težave pri dojemanju zvočnih informacij,

- težave pri razumevanju v hrupu in težavnih zvočnih okoljih (odmev),

- težave pri govorjenju,

- izguba ravnotežja, 
- hitrejša izguba pozornosti v medosebni komunikaciji, še posebej v okolju z veliko ljudmi,

- tinitus (stalni šum v ušesu),

- nekateri naglušni slišijo samo na eno uho in ne slišijo stereo zvoka oziroma ne slišijo, od kod prihaja zvok,

- naglušni s slušnim aparatom razumejo govor največ do nekaj metrov zaradi klasične slabosti mikrofonov za zajemanje zvokov na daljavo,

- gluhi imajo povečani periferni vid v primerjavi s slišečimi,

- hitrejše branje podnapisov v primerjavi s slišečimi.

\subsection{Osebe s težavami v kognitivnem funkcioniranju}

Glede na različne vire [Gillen, 2009] delimo tiste, ki se soočajo s težavami v kognitivnem funkcioniranju, skrajšano na osebe:

- s težavami v duševnem zdravju,

- z motnjami v duševnem razvoju,

- s pridobljenimi poškodbami glave,

- z motnjami avtističnega spektra.

\subsubsection{Osebe $\mathrm{z}$ motnjami v duševnem razvoju}

Motnja v duševnem razvoju je nevrološko pogojena razvojna motnja, ki nastopi pred dopolnjenim osemnajstim letom starosti in se kaže $\mathrm{v}$ pomembno manjših intelektualnih sposobnostih ter pomembnih odstopanjih prilagoditvenih spretnosti.

Pri osebah z motnjami v duševnem razvoju ugotavljamo [Kobolt, 2015]:

- Pomembno znižano splošno intelektualno raven ali raven funkcioniranja vključno z zmanjšanimi sposobnostmi učenja, sklepanja in reševanja problemskih okoliščin ter zmanjšanimi sposobnostmi abstraktnega mišljenja in presojanja.

- Zmanjšane prilagoditvene funkcije oziroma spretnosti. Raven prilagoditvenih funkcij opredelimo glede na kronološko starost osebe ter s pomembnim odstopanjem na vsaj dveh na vsaj dveh področjih prilagoditvenih funkcij od naštetih - socialnem, konceptualnem in praktičnem. Primanjkljaji v prilagoditvenih spretnostih se pomembno izražajo na področjih govora in komunikacije, pri skrbi 
zase, samostojnosti, socialnih spretnostih, učnih in delovnih zmožnostih, funkcionalnih učnih sposobnostih, sposobnostih praktičnih znanj, skrbi za lastno varnost.

Motnje v duševnem razvoju se lahko pojavljajo skupaj z drugimi razvojnimi motnjami. Stopnje motnje ne definiramo le na osnovi skupnega izida IQ, temveč na osnovni ugotovljenih prilagoditvenih funkcij. Glede na stopnjo motnje v duševnem razvoju ločimo osebe z lažjo, zmerno, s težjo in težko motnjo v duševnem razvoju.

\subsubsection{Osebe s težavami v duševnem zdravju}

Osebe s težavami v duševnem zdravju pogosto ovira huda stigmatizacija, tako pri iskanju zaposlitve kot pri navezovanju medčloveških stikov. Večina se spopada s hudimi stiskami zaradi odrinjenosti od družbe, pogosto lahko navezujejo stike le znotraj skupine enakih. Pri nekaterih se lahko pojavijo tudi čustveni odzivi na različne neprijetne dogodke $\mathrm{v}$ okolici, predvsem v akutni fazi bolezni.

\subsubsection{Osebe po poškodbi glave}

Med osebe po poškodbi glave in možganov sodijo posamezniki po prometnih in drugih nesrečah, možganski kapi, osebe s tumorji itd.

\subsubsection{Avtisti}

Avtizem je nevrološka razvojna motnja, ki jo lahko odkrijemo pri otrocih že pred tretjim letom starosti. Avtizem vpliva na razvoj tistih predelov možganov, ki so povezani z vzpostavljanjem socialnih stikov, s komunikacijo in kognitivnimi funkcijami. Otroci z avtizmom imajo primanjkljaje na področju besedne in nebesedne komunikacije, socializacije in pri razvoju igre [Kesič, 2010].

Avtisti imajo težave s socializacijo in stiki z različnimi osebami, še posebej z neznanimi. Prav tako imajo lahko težave pri učenju, ker pogosto menjavajo pozornost, potrebujejo zaporedne, enake postopke za izvedbo nalog. Dodatno imajo težave z motoričnimi sposobnostmi in odzivi na vizualne dražljaje, kar jih dela negotove in plašne. 


\subsection{Osnovne smernice}

Glede na omenjene značilnosti in potrebe posameznih skupin lahko zaključimo, da so razvojne zahteve najzahtevnejše pri oblikovanju in izdelavi spletnih strani ter aplikacij za osebe $\mathrm{s}$ težavami v kognitivnem funkcioniranju. In teh je tudi v resnici bistveno več kot ostalih oseb. V Sloveniji, na primer, je bilo pri rehabilitacijskih komisijah Zavoda za zaposlovanje v letih od 2014 do 2019 obravnavanih okrog 3.700 oseb s težavami v kognitivnem funkcioniranju, medtem ko je bilo slabovidnih in naglušnih približno enako število, in sicer okrog 250 na vsako skupino (Tabela 3) [MDDSEM, 2020].

Tabela 3: Število ocenjenih oseb pri rehabilitacijskih komisijah z nosilno funkcijo po Mednarodni klasifikaciji funkcioniranja (vid in sorodne funkcije, sluh in vestibularne funkcije, splošne in specifične duševne funkcije) in z diagnozo po Mednarodni klasifikaciji bolezni (bolezni očesa in adneksov, bolezni ušesa in mastoida, duševne in vedenjske motnje) v obdobju od 1. 1. 2014 do 31. 12. 2019.

\begin{tabular}{|l|c|c|l|l|l|l|l|}
\hline $\begin{array}{l}\text { Število ocenjenih oseb pri } \\
\text { rehabilitacijskih komisijah z } \\
\text { nosilno funkcijo po MKF }\end{array}$ & $\%$ & \multicolumn{2}{|l|}{$\begin{array}{l}\text { Stevilo ocenjenih oseb pri } \\
\text { rehabilitacijskih komisijah } \\
\text { z diagnozo po MKB }\end{array}$} & $\%$ & $\begin{array}{l}\text { Skupaj } \\
\text { MKF in } \\
\text { MKB }\end{array}$ & $\%$ \\
\hline $\begin{array}{l}\text { Vid in sorodne funkcije } \\
\text { (b210-b229) }\end{array}$ & 257 & 6 & $\begin{array}{l}\text { Bolezni očesa in } \\
\text { adneksov (H00-H59) }\end{array}$ & 232 & 8,6 & 489 & 7 \\
\hline $\begin{array}{l}\text { Sluh in vestibularne } \\
\text { funkcije (b230-b249) }\end{array}$ & 244 & 5,7 & $\begin{array}{l}\text { Bolezni ušesa in } \\
\text { mastoida (H60-H95) }\end{array}$ & 248 & 9,2 & 492 & 7 \\
\hline $\begin{array}{l}\text { Splošne in specifične } \\
\text { duševne funkcije (b110- } \\
\text { b189) }\end{array}$ & 3782 & 88,3 & $\begin{array}{l}\text { Duševne in } \\
\text { vedenjske motnje } \\
\text { (F00-F99) }\end{array}$ & 2226 & 82,2 & 6008 & 86 \\
\hline Skupaj & $\mathbf{4 2 8 3}$ & $\mathbf{1 0 0}$ & Skupaj & $\mathbf{2 7 0 6}$ & $\mathbf{1 0 0}$ & $\mathbf{6 9 8 9}$ & $\mathbf{1 0 0}$ \\
\hline
\end{tabular}

Vir: Zavod Republike Slovenije za zaposlovanje

V osnovi bi bila torej najpomembnejša naloga za dostopnost oblikovati enostavnejša besedila, slike in video posnetke, nato pa urediti še podnapise za osebe z okvaro sluha in opis slik za slabovidne, če omenimo samo najnujnejše rešitve oblikovanja. Seveda pa je treba za aplikacije urediti veliko več, kar je tudi del standardov, kot je WCAG (angl. Web Content Accessibility Guidelines) [W3C, 2018] in ETSI EN 301549 (Zahteve za dostopnost izdelkov in storitev IKT) [ETSI, 2016]. 


\section{Osnovna pravila in načela dostopnosti ter priporočila in standardi}

Ko oblikujemo dostopne spletne strani in aplikacije, jih moramo vedno, ne glede na čas in kraj, oblikovati tako, da so dostopne vsakomur, ne glede na njegovo oviro. Dostopnost tako razumemo kot pravila in načela ter metode, ki jih je treba upoštevati pri analizi, oblikovanju, izdelavi, ocenjevanju in vzdrževanju ter posodabljanju spletišč in mobilnih aplikacij, da bi postali takšni, da bi jih lahko uporabili vsi uporabniki [Demšar, 2015].

\subsection{Kaj prinaša dostopnost?}

Cilj dostopnosti je zagotoviti dostopnejša spletišča in mobilne aplikacije na podlagi skupnih zahtev po dostopnosti. Da bi odpravili razdrobljenost notranjega trga, je treba nacionalne ukrepe približati ravni EU na podlagi že dogovorjenih zahtev in standardov dostopnosti spletišč in mobilnih aplikacij organov javnega sektorja. S tem bi se zmanjšala negotovost za razvijalce spletišč in spodbudila interoperabilnost. Uporaba tehnološko nevtralnih zahtev po dostopnosti ne bo ovirala inovacij, ampak jih bo lahko celo spodbujala in bolje sledila nenehno se razvijajočim se trendom.

Zahteve po dostopnosti se ne bi smele uporabljati za vsebino, ki se nahaja izključno na tistih mobilnih napravah ali uporabniških agentih zanje, ki so razviti za zaprte skupine uporabnikov ali posebno uporabo v določenih okoljih ter niso na voljo velikemu delu javnosti oziroma jih ta ne uporablja [Demšar, 2015]. 
Kaj to pravzaprav pomeni za oblikovalce spletišč in mobilnih aplikacij? Kratek odgovor je, da bodo morali biti veliko pozornejši na zahteve in potrebe celotne populacije in ne samo neke določene ciljne populacije, sploh če gre za javno dostopna spletišča in mobilne aplikacije. Daljši odgovor je, da se bodo morali poučiti o različnih ravneh sposobnosti različnih uporabnikov in kako uporabljajo računalnike [Accessibility Basics, 2011]. Če bodo razvijalci znali upoštevati te zahteve, potem bodo njihove spletne strani lahko uporabljali uporabniki, kot so:

- slepi in slabovidni, ki uporabljajo bralnike zaslonov ali braillovo tablico;

- slabovidni, ki potrebujejo 200-odstotno velikost fontov;

- gibalno ovirani, ki potrebujejo sistem za sledenje očem za premikanje miške;

- gluhi in naglušni, ki potrebujejo podnapise $\mathrm{k}$ video posnetkom.

Seveda pa je treba upoštevati še druge zahteve, ki so sicer navedene v standardih.

\subsection{Zakaj je dostopnost pomembna?}

V Evropi in Sloveniji je dostopnost pomembna iz preprostega razloga. Vsi smo namreč različni in vsi imamo pravico do uporabe spletišč ter mobilnih aplikacije ne glede na telesne ali kognitivne ovire. Dodatno pa lahko naštejemo tudi druge razloge, ki jih moramo upoštevati pri razvoju [Accessibility Basics, 2011]:

- V večini evropskih državah to zahtevajo zakoni.

- Ne želimo izključiti nobenega potencialnega uporabnika.

- Dostopna spletišča so umeščena više $\mathrm{v}$ iskalnih mehanizmih.

- S tem pokažemo ustrezno etičnost, kar uporabniki cenijo.

- Če upoštevamo standarde, lahko pridobimo večjo povezljivost sistemov.

- Če upoštevamo pri razvoju najprej zahteve in potrebe oseb z različnimi oblikami oviranosti, potem lahko pričakujemo, da bodo zaradi s tem pridobili tudi ostali, vključno z olajšano uporabo sistemov

Ključ do dostopnosti je razmišljanje o tem, kakšne težave se lahko pojavijo pri uporabi in kako bi jih reševali za posamezne uporabnike. Pomembno je zato, da že takoj na začetku razvoja razmišljamo o vseh možnostih in jih ustrezno načrtujemo ter upoštevamo že pred samim programiranjem. Treba je vsaj razmišljati o možnostih, da nekateri uporabniki ne bodo mogli uporabljati miške, tipkovnice, zaslona, zvočnikov in drugih naprav. 


\subsection{Zahteve po interoperabilnosti}

Interoprabilnost označuje sposobnost sistema ali izdelka, da brez posebnega napora uporabnika deluje $z$ drugimi sistemi ali izdelki [Martinez Usero, 2006]. V bistvu se zahteve po interoperabilnosti spreminjajo od situacije do situacije. Nove tehnologije in rešitve pogosto prinesejo tudi zahteve po prilagajanju drugih programov na nove pogoje, kar ni vedno najugodnejša rešitev. To pomeni, da morajo razvijalci druge opreme izdelati nove, nadgrajene različice svojih programov, ki jih je treba prilagoditi na nove razmere. Razvoj takšnih produktov je lahko tudi časovno zamuden in nepopoln, če ga je treba zelo hitro ponuditi na tržišču.

Na primer, program JAWS for Windows [Freedom Scientific, 2020] je orodje, pri katerem nova različica izide skoraj vsako leto. Pri tem je treba za vsako novo doplačati skoraj polovico vsote prve. Pri tem je jasno, da veliko uporabnikov še vedno uporablja stare inačice orodja JAWS for Windows, zato ostanejo tudi brez nadgradenj operacijskega sistema. To pa lahko vodi v veliko nevarnost zaradi izpostavljenosti podatkov nezaželenim napadom in vdorom.

$\mathrm{V}$ tem primeru, ko oblikujemo nove spletne strani ali aplikacije, poskušamo upoštevati tudi interoperabilnost $\mathrm{z}$ veliko mero sposobnosti sodelovanja med uporabnikom in tehnologijo. Poznamo štiri vidike [W3C, 2020]:

1. Progresivno spreminjanje produktov, ki jih sproti testiramo za podporo dostopnosti.

2. Uporabniku omogočimo, da izklopi nezaželene funkcije.

3. Ponudimo alternativne izvedenke $z$ enako vsebino ali funkcionalnostmi.

4. Ponudimo uporabnikom informacijo o podpornih tehnologijah in omogočimo povezave do različnih podjetij, ki nudijo takšne tehnologije.

Zgodi se lahko, da nekateri uporabniki uporabljajo operacijske sisteme MacOS ali pa celo Linux, medtem ko institucija nudi posebne rešitve, ki so izdelane, na primer, samo za Windows okolje. Seveda interoperabilnost $\mathrm{v}$ tem primeru ni mogoča, saj izdelki niso povezljivi z MacOS in Linux. Pomembno je zato, da se že v najzgodnejši zasnovi začne razvoj izdelka, ki je prenosljiv na vse platforme, in upošteva vse znane standarde za razvoj aplikacij. 
Interoperabilnost tako koristi končnim uporabnikom, saj lahko, na primer, uporabniške agente uporabljajo za dostop do spletišč in mobilnih aplikacij ne glede na platformo. Interoperabilnost bi koristila tudi ponudnikom ter kupcem proizvodov in storitev, povezanih z dostopnostjo spletišč in mobilnih aplikacij.

\subsection{Smernice za dostopnost spletnih vsebin - WCAG}

Da bi dosegli čim večjo interoperabilnost in ustrezno enako dostopnost tako za spletišča kot tudi za mobilne aplikacije, so razvili smernice za dostopnost spletnih vsebin (angl. Web Content Accessibility Guidelines - WCAG) [W3C, 2018], ki so v veljavi tudi kot mednarodni standard ISO/IEC 40500:2012. Nastale so ga v okviru organizacije World Wide Web Consortium (W3C), ki med drugim razvija tudi spletne standarde, kot so HTML, XML, CSS in drugi.

V okviru tega standarda so smernice organizirane po štirih osnovnih načelih. Ta opisujejo osnovne cilje, h katerim morajo stremeti ustvarjalci spletišč in mobilnih aplikacij.

\subsubsection{Načela WCAG}

Načela standarda, da so uporabna za vsakogar, delimo na štiri osnovna:

- Zaznavnost - upoštevajo se vsa tri glavna čutila, ki jih potrebujemo za interaktivno delo: vid, sluh in otip. Vsebuje 29 meril uspešnosti.

- Upravljivost - določajo se načini upravljanja (navigacija v uporabniškem vmesniku). Vsebuje 29 meril uspešnosti.

- Razumljivost - določajo se načini za pravilno interpretacijo vsebine. Vsebuje 17 meril uspešnosti.

- Robustnost - določa se združljivost s sedanjimi in z bodočimi tehnologijami. Vsebuje 3 merila uspešnosti.

\section{Zaznavnost}

Zaznavnost pomeni, da morata biti vsaka informacija in komponenta predstavljeni tako, da ju končni uporabnik lahko zazna. Natančneje to pomeni, da morajo biti vse komponente in informacije podane tako, da so vidne oziroma jasne njihovim čutom. To vključuje alternativno besedilo za vsako slikovno vsebino, alternative za vse medije, ki temeljijo na času. To pomeni besedilne prepise, podnapise, tudi za posnetke $\mathrm{v}$ živo, 
tolmače znakovnega jezika. Vsebina mora biti pripravljena tako, da jo je moč predstaviti na različne načine brez izgube informacij. Na primer veliki, povečani panoji, branje ob pomoči braillove vrstice, bralniki zaslona, na primer pretvorba v razne simbole ali zgolj poenostavljen jezik.

\section{Upravljivost}

Operabilnost je komponenta, ki se nanaša na upravljanje uporabniškega vmesnika tako, da ta ne zahteva interakcije. To pomeni, da mora spletišče imeti popoln dostop do vsebine prek tipkovnice. Pri tem načelu tudi ne sme imeti izjem. Uporabniku mora biti, v primeru časovno omejenih vsebin, prilagojena možnost samostojnega upravljanja časa za prikaz. Za doseganje najvišje stopnje se je priporočljivo takšnim vsebinam odpovedati. Prav tako se je priporočljivo povsem izogniti vsebini, ki utripa, saj lahko povzroči tveganje, kot je epileptični napad, pri občutljivih uporabnikih. Na spletnem mestu morata biti jasno označena navigacija, da uporabnik natančno, v vsakem trenutku ve, kje na spletni strani se nahaja, in omogočeno iskanje vsebine.

\section{Razumljivost}

Načelo razumljivosti pomeni, da mora biti vsa vsebina predstavljena tako, da jo uporabniki razumejo, prav tako morajo biti razumljive vse operacije. To vključuje berljivost vseh informacij, jasno zasnovan jezik, dodaten jezik ali, za doseganje najvišje ravni skladnosti AAA, definicije vseh nenavadnih besed in odstavkov, tudi poenostavljene in skrajšane različice odstavkov. Spletna stran mora biti zasnovana predvidljivo in konsistentno. Prav tako je potrebna pomoč pri popravljanju uporabniških napak in njihovem preprečevanju.

\section{Robustnost}

Robustnost pomeni, da je vsebina pripravljena na tak način, da je lahko zanesljivo predstavljena s tehničnimi pripomočki, ki jih občutljive osebe uporabljajo. To vključuje dostopnost vsebin kljub spreminjajoči se tehnologiji in pripomočkom. V to priporočilo so vključeni tudi uporabniki, ki uporabljajo mobilne naprave in tablice.

Če se izkaže, da katero koli od teh štirih načel ne velja, potem osebe z različnimi oblikami oviranosti ne bodo sposobne uporabljati spletišča ali mobilne aplikacije. 
Omenjena štiri načela za dostopnost so pretvorjena v merila uspešnosti. $\mathrm{V}$ navodilih WCAG 2.1 je tako 78 meril uspešnosti. Ta je mogoče preizkusiti z merili, ki so podlaga evropskega standarda ETSI EN 301 549 -Zahteve za dostopnost izdelkov in storitev IKT [ETSI, 2016], in sicer ob pomoči usklajenih standardov in skupne metodologije za preizkušanje skladnosti vsebine spletišč ter mobilnih aplikacij s temi načeli.

Če se zahteve po dostopnosti ne uporabljajo, se bodo v skladu z evropsko zakonodajo, Konvencijo ZN in drugo ustrezno zakonodajo še vedno uporabljale zahteve po »razumnih prilagoditvah« in bi jih bilo treba po potrebi spoštovati predvsem na delovnem mestu in v okviru izobraževanja. Pri vsaki oceni, v kolikšni meri zahtev po dostopnosti ni mogoče izpolniti zaradi nesorazmernega bremena, bi bilo treba upoštevati le legitimne razloge. Neprednostna obravnava in pomanjkanje časa ali znanja ne bi smela šteti za legitimne razloge. Prav tako ne bi smelo biti legitimnih razlogov za to, da se ne zagotovijo ali razvijejo sistemi programske opreme za upravljanje vsebine spletišč in mobilnih aplikacij na dostopen način, saj so na voljo možnosti za zagotovitev.

Vsako načelo v WCAG vsebuje svoja navodila in merila uspešnosti, s katerimi nato preverjamo dostopnost. Na voljo je sicer veliko več navodil za uporabniško prijaznost, vendar so avtorji WCAG uporabili samo tista, ki so potrebna za dostopnost.

\subsubsection{Navodila WCAG}

Pri vsakem načelu je na voljo tudi seznam navodil, ki jih je treba uporabiti, da lahko potrdimo posamezno načelo. WCAG 2.1 vsebuje vsega skupaj 12 navodil, razporejenih po vseh 4 načelih. Eno izmed pomembnejših navodil je, da mora biti vsebina neposredno dostopna čim širšemu krogu oseb in da se jo lahko prikaže tudi v različnih predstavitvenih oblikah, prilagojenih različnim osebnostnim oviram, tako senzornim, fizičnim ali kognitivnim.

\subsubsection{Merila uspešnosti WCAG}

Vsako posamezno navodilo vsebuje merila uspešnosti, s katerimi je moč preveriti skladnost s smernicami. Gre za točke preverjanja (angl. checkpoints), ki so napisane tako, da preverjamo njihovo skladnost z izjavo, ali ustreza ali ne. Vsa merila uspešnosti so zasnovana tako, da so čim bolj tehnološko nevtralna. 
Večino meril uspešnosti je mogoče preverjati tudi s samodejnimi orodji, kot so Achecker, WAVE in drugi [Priloga 3], za ostale pa moramo uporabiti strokovnjake za preizkušanje $\mathrm{v}$ živo, ki dobro poznajo zahteve in potrebe oseb z različnimi oblikami oviranosti. Za testiranje se lahko uporablja hevristična metoda [Nielsen, 1990] ali pa klasično testiranje uporabnosti, ki je del klasičnega ocenjevanja pri komunikaciji človek-računalnik [Holzinger, 2005].

\subsubsection{Raven skladnosti}

Vsako merilo uspešnosti, definirano v WCAG, s katerim preverjamo skladnost s smernicami, ima definirano svojo raven skladnosti.

Te ravni skladnosti so poimenovane $z$ :

- raven $\mathbf{A}$ - nizka raven skladnosti,

- raven AA - srednja raven skladnosti in

- raven AAA - visoka raven skladnosti z načeli.

Najvišjo stopnjo ravni skladnosti AAA je običajno zelo težko doseči, saj ta pomeni, da je skladnost usklajena s popolnoma vsemi merili uspešnosti, ki so določena v WCAG. Standard ETSI EN 301549 [ETSI, 2016] zato določa, da je za dosego zahtev standarda treba doseči vsaj raven AA, ki določa srednjo raven skladnosti. Na ta seznam tako sodijo vsa merila uspešnosti, ki so določena za raven A, kot tudi merila uspešnosti, določena za raven $\mathrm{AA}$.

\subsubsection{Seznam meril uspešnosti za dosego ravni AA}

V tabeli v prilogi [Priloga 1] je naveden seznam vseh potrebnih $\mathbf{5 0}$ meril uspešnosti za dosego ravni skladnosti $\mathrm{A}$ in AA, ki jih je treba izpolniti, da bi bila spletišča in mobilne aplikacije v skladu z ravnmi iz navodil za dostopnost do spletnih vsebin WCAG 2.1, ki so del standarda ETSI EN 301549 [ETSI, 2016].

V elektronski različici te monografije so v tabeli v prilogi [Priloga 1] dodane še povezave do navodil v izvirniku, ki se nahajajo na spletišču W3C, tako da lahko bralec neposredno dostopa do posameznega besedila merila uspešnosti na spletu. 
Tabela v prilogi [Priloga 1] je v pomoč vsem ocenjevalcem spletišč in mobilnih aplikacij, ko želijo preverjati skladnost $\mathrm{z}$ načeli dostopnosti. Na prvi pogled deluje tako, da je treba res čisto vsako merilo uspešnosti uresničiti, če naj bi bili produkti dostopni, vendar je zelo težko takoj izpolniti popolnoma vsa merila.

V naslednji prilogi [Priloga 2] so kot dodatek navedena še natančnejša navodila za posamezna merila uspešnosti, ki jih lahko uporabimo za hitrejše in enostavnejše preverjanje ustreznosti določilom dostopnosti.

\subsubsection{Znakovni jezik in njegova raba}

V standardu ETSI EN 301549 je navedeno, da uporaba znakovnega jezika (predposneto) spada $\mathrm{v}$ raven AAA, kar pomeni, da po standardu znakovni jezik ni potreben, je pa zaželen. Ker pa se v Sloveniji uporablja Zakon o uporabi slovenskega jezika, je treba lokalni zakon upoštevati v primerih, kjer so realizirane vsebine upravnih postopkov na spletni strani ali mobilnih aplikacijah. $\mathrm{V}$ tem primeru moramo upravni postopek obvezno prevesti tudi $\mathrm{v}$ slovenski znakovni jezik.

\subsection{Kako brati standard ETSI EN 301 549?}

Standard ETSI EN 301549 [ETSI, 2016] je bil v osnovi namenjen javnemu naročanju, zdaj pa zadnja različica vključuje minimalne zahteve evropske Direktive o dostopnosti spletišč in mobilnih aplikacij organov javnega sektorja [EU, 2016].

Standard ETSI EN 301549 vsebuje veliko število zahtev s ciljem pokriti raznolike zahteve rešitev, ki jih ponujata informacijska in komunikacijska tehnologija. V njem so navedene zahteve za funkcije in fizične karakteristike programske opreme. Ne glede na tip uporabe standarda je pomembno, da za branje standarda razumemo, katere zahteve potrebujejo osebe $\mathrm{z}$ različnimi oblikami oviranosti za določen produkt ali storitev $\mathrm{v}$ določeni situaciji ali vsebini.

Ocenjevanje zahtev dostopnosti velikokrat ne bo dalo pozitivnih ali negativnih rezultatov. Včasih bo ocenjevalec ali razvijalec ostal v sivi, nejasni coni, kjer bo moral poiskati druge rešitve ali alternative za določeno skupino uporabnikov. 
Za ta standard je značilno, da so stavki oblikovani tako, da je treba preveriti prvi del stavka, in če ta ustreza, potem mora oblikovalec upoštevati pri izvedbi drugi del stavka. Če prvi del stavka ne drži, ga lahko preskočimo.

Primer takšne zahteve tega standarda je: »Kjer ima strojna oprema IKT glasovni izhod, mora ponuditi $[. ..] \ll . V$ tem primeru imamo dve možnosti:

- če naš produkt ali storitev nudi govor, potem moramo izpolniti drugi del zahteve;

- če naš produkt ali storitev ne nudi govora, potem lahko to zahtevo preskočimo.

Ostali del besedila v standardu označuje povezave med zahtevami standarda in potrebami oseb z različnimi oblikami oviranosti. Ta del pomaga oblikovalcu, da se lažje odloča o najboljši mogoči rešitvi glede na potrebe določene skupine. Vsekakor pa si mora oblikovalec pred tem zastaviti vsaj naslednja vprašanja:

- V kakšni situaciji se bo uporabljala določena rešitev?

- Katere zahteve ni treba izvesti, ampak je bolje uporabiti druge alternative za kompenzacijo, na primer za sprejemno pisarno?

- Kakšni so stroški za izvedbo te zahteve oziroma alternative?

- Ali bi se lahko nerešene zahteve standarda izvedle v naslednji različici?

Z odgovori na ta vprašanja si lahko oblikovalci in programerji pomagajo pri razvoju produkta in storitev, ki bi bil najprimernejši za posamezno skupino oseb z različnimi oblikami oviranosti.

V naslednjem poglavju se bomo dotaknili osnovnih načel za oblikovanje dostopnih produktov in storitev. 


\section{Osnovna pravila načrtovanja in oblikovanja digitalnih produktov $z$ vidika dostopnosti}

Po dozdajšnjih ugotovitvah lahko zaključimo, da morajo biti digitalni produkti dostopni tako na fizični ravni kot na senzorni in miselni. Tem trem ravnem sledijo primerno tudi osnovne smernice WCAG - zaznavnost, upravljivost, razumljivost in robustnost. Če torej pravilno upoštevamo smernice WCAG, bo naš produkt tudi ustrezno oblikovan glede na potrebe in zahteve oseb s posebnimi potrebami.

Če gledamo s stališča načrtovanje in oblikovanja, je razvidno, da razvoj dostopne vsebine samodejno vodi tudi $\mathrm{v}$ izvedbo dobrega uporabniškega oblikovanja. Če torej želimo omogočiti dostopne produkte, morajo biti načela dostopnosti sestavni del oblikovanja uporabniške izkušnje oziroma uporabniškega vmesnika. Prav tako mora biti dostopnost sestavni del testiranja in ocenjevanja uporabniških vmesnikov. Produkti, kamor štejemo tako programsko opremo kot tudi strojno, lahko s svojo dostopnostjo bistveno pripomorejo k njihovemu izboljšanemu sprejemanju. Na primer, če že takoj na začetku oblikujemo uporabniške vmesnike tako, da bodo primerni za starejše osebe, lahko pričakujemo, da bodo produkt zagotovo sprejele tudi digitalno bolj pismene osebe.

Pri načrtovanju in oblikovanju dostopnosti moramo tako upoštevati spletne standarde in pravila za načrtovanje učinkovite uporabniške izkušnje ter poznati strojno ter programsko tehnologijo pripomočkov za dostopnost (Slika 4) [Richens, 2015]. S prekrivanjem vseh treh vrst znanja lahko nato pričakujemo, da bodo načrtovalci in oblikovalci sposobni primerno oblikovati dostopne produkte ter storitve. 


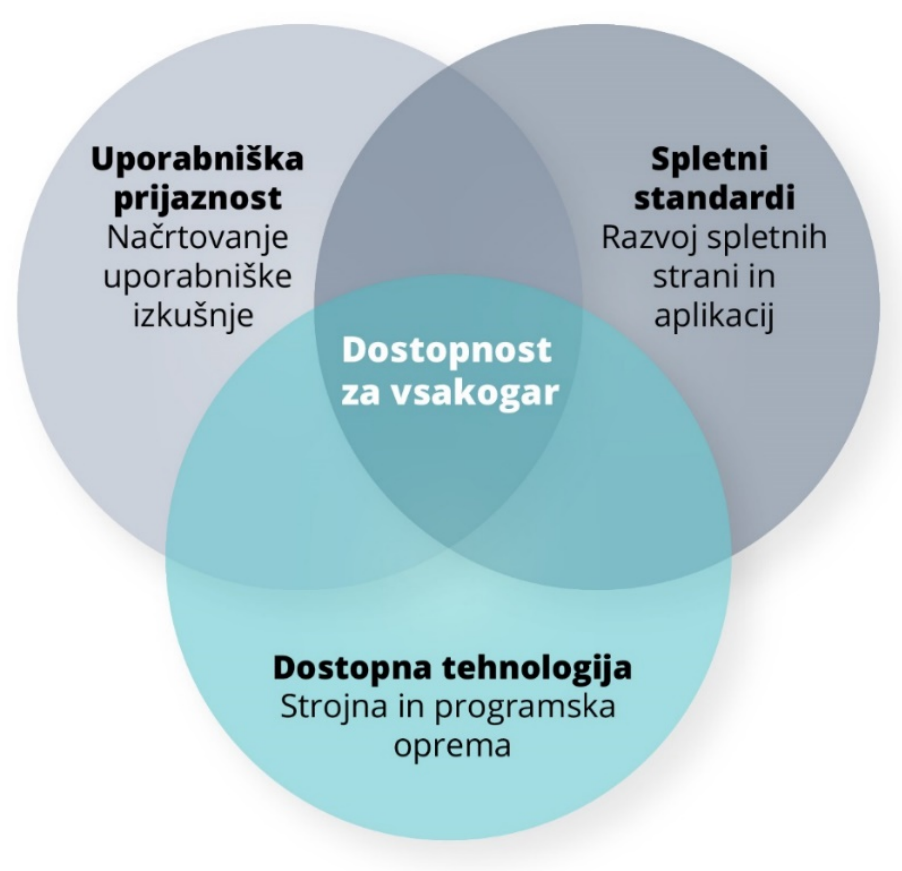

Slika 4: Področja razvoja dostopnosti za vsakogar

Dostopnost produktov za osebe $\mathrm{z}$ različnimi oblikami oviranosti $\mathrm{v}$ širšem smislu ne pomeni, da upoštevamo arhitektonske ovire samo za invalidske vozičke, ampak gre za bistveno širšo sliko, kjer moramo upoštevati uporabo vsakdanjih stvari tako doma kot na poti in v službi ali v nekem družbenem okolju. Na primer, sodobni načrtovalci v zadnjem času zelo radi oblikujejo okrogle kljuke namesto klasičnih kljuk (Slika 5) [Kalbag, 2017]. Jasno je, da bo večina oseb $\mathrm{z}$ različnimi oblikami oviranosti $\mathrm{v}$ resnici imela večje težave pri uporabi okroglih kljuk, ki jih prijemamo in obračamo s celo roko, kot pa s klasičnimi, kjer samo položimo roko nanjo in pritisnemo navzdol. Podobna situacija je na cesti, kjer nekateri semaforji tudi z zvokom signalizirajo, da lahko pešci gredo čez cesto. Drugi primer so, na primer, podnapisi v filmih, ki so primerni za osebe z slušnimi ovirami. Te oblikovalske rešitve pa ne pomenijo, da so primerne samo za osebe $z$ različnimi oblikami oviranosti, ampak z njimi pridobijo vsi. Podnapise, na primer, lahko tako uporabijo tudi vsi, ki se nahajajo v hrupnem okolju, denimo gostišču, in bi radi spremljali, kaj se dogaja na televizijskem zaslonu, nameščenem $\mathrm{v}$ kotu.
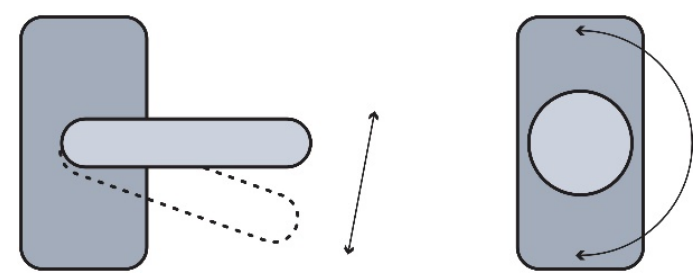

Slika 2: Uporaba kljuke na levi zahteva samo rahel pritisk navzdol.

Pri krožni kljuki na desni pa sta potrebna zahtevni prijem in obračanje roke. 


\subsection{Osnovna pravila načrtovanja}

V svojih navodilih Pernice in Nielsen [Pernice, 2001] ugotavljata, da se vsako oblikovanje, tudi oblikovanje $\mathrm{z}$ upoštevanjem dostopnosti, začne $\mathrm{z}$ osnovnimi pravili za dobro oblikovanje. V bistvu se moramo zavedati, da je najpomembneje, da oblikujemo lepo, zanimivo in učinkovito. Če je za običajne uporabnike pomembno, da je delo s produktom učinkovito, hitro in stabilno, je za osebe $z$ različnimi oblikami oviranosti pomembneje, da lahko sploh izvedejo svojo nalogo z uporabo digitalnih pripomočkov.

Nekatera ustrezna pravila oblikovanja, na katera moramo biti pozorni z vidika poenostavljenosti, so predvsem [Pernice, 2001]:

- Oblikujmo produkte in spletne strani ob upoštevanju zahtev in potreb vseh uporabnikov.

- Uporabimo jasna, kratka in razumljiva besedila ter se izogibajmo marketinškemu jeziku.

- Ponudimo raje manj možnosti, po načelu »Manj je več«, in vključimo samo najpomembnejše.

- Ne vključujmo slik ali glasbenih učinkov samo zato, ker menimo, da bo sistem lepši na pogled.

Oblikovanje za uporabniško prijaznost in dostopnost bo izboljšalo uporabniške izkušnje vseh in ne samo oseb z različnimi oblikami oviranosti. Velikokrat vidimo na tržišču produkte, ki so v osnovi namenjeni samo zelo ozki skupini ljudi, vendar bi lahko njihova uporaba pripomogla k izboljšanju tudi za ostale uporabnike. Lep primer so podnapisi za video posnetke. Čeprav so v osnovi bili namenjeni gluhim in naglušnim, jih lahko s pridom uporabljajo tudi ljudje, ki se učijo jezika, kot so migranti, starejši ljudje in osebe, ki delajo ali se nahajajo v hrupnih okoljih. Tudi naslednji primeri so takšni, kjer imajo korist vsi uporabniki:

- Logična tabulatorska mesta pomagajo uporabnikom uporabljati bralnik zaslona, povečevanje zaslona ali drugo pomožno tehnologijo za osebe z gibalnimi ovirami, vendar lahko to pomaga tudi izkušenim uporabnikom, saj se lahko s tem veliko hitreje premikajo po zaslonu samo z uporabo tipkovnice.

- Prazen prostor med povezavami in besedilom omogoča uporabnikom, da lahko hitreje in natančneje zadenejo povezavo. To velja za vse uporabnike, ne samo za osebe z različnimi oblikami oviranosti. 
- Različni, močnejši barvni kontrasti so sicer primerni za barvno slepe osebe, vendar je tudi za običajne uporabnike tako veliko lažje opazovati, tudi pod močnim soncem.

Vsak dober načrtovalec ve, da lahko s svojim oblikovanjem pomaga, vendar pa lahko tudi prizadene določeno skupino uporabnikov. A ostaja dejstvo, da oblikovanje v smislu dostopnosti že v dovolj zgodnji fazi načrtovanja izjemno pripomore tudi k uspešni izkušnji vseh uporabnikov v kasnejši fazi načrtovanja. Pomembno je, da poznamo načrtovalna področja in pravila oblikovanja v njih ter dobre in slabe oblikovalne primere.

\subsubsection{Načrtovalna področja in pravila oblikovanja}

Ko začnemo načrtovati in oblikovati osnovne značilnosti produktov, moramo upoštevati vsaj naslednja štiri področja (Slika 6) [A11Portal, 2020; Sethfors, 2017]:

- vizualno načrtovanje,

- slike,

- povezave,

- struktura.

Pri vsakem od teh področij je treba upoštevati še pravila za oblikovanje podelementov, kot so, na primer, barva in vizualni slogi pri vizualnem načrtovanju. Če načrtovalec sledi osnovnim napotkom, ki so navedeni v tem podpoglavju, lahko pričakuje že v osnovi zelo velik delež dostopnosti. Ostali del dostopnosti, ki se nanaša bolj na interaktivnost in varnost, pa se upošteva in ocenjuje posebej. 


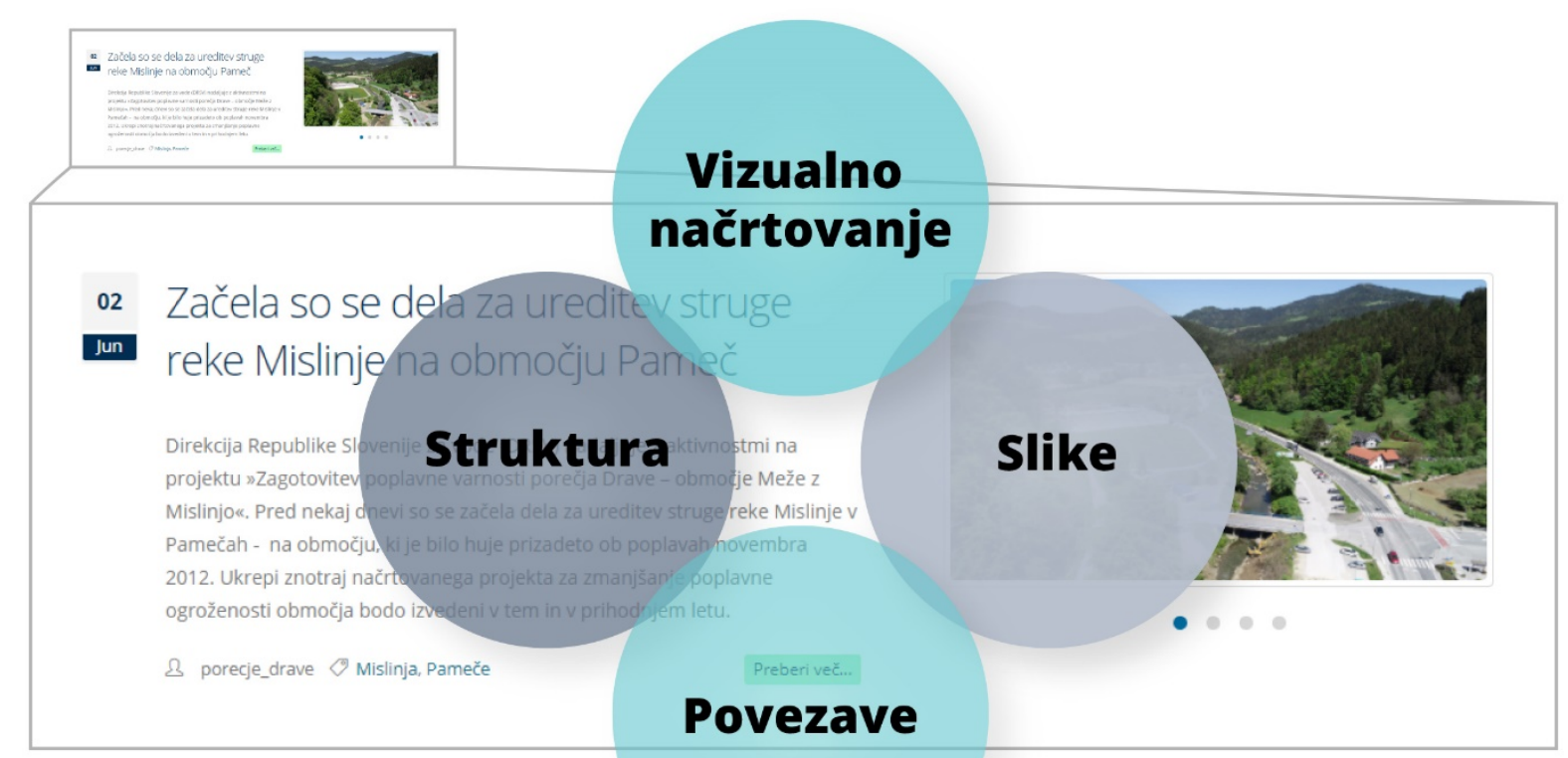

Slika 6: Načrtovalna področja

V nadaljevanju so tako navedena nekatera osnovna pravila s primeri, kako naj upoštevamo načela oblikovanja, da bo digitalni produkt ustrezno dostopen.

\subsubsection{Vizualno načrtovanje}

Pri vizualnem načrtovanjem se moramo osredotočiti predvsem na naslednje elemente:

- Barva

- Preverimo ustrezno kombinacijo barv in barvne kontraste za ospredje in ozadje. Največkrat imajo ljudje težave zaradi rdeče barve, sledi pa ji zelena. Pri tem je treba upoštevati tudi težave pri zaznavanju barv in kontrastov pri močni svetlobi, na primer, na soncu (Slika 7).
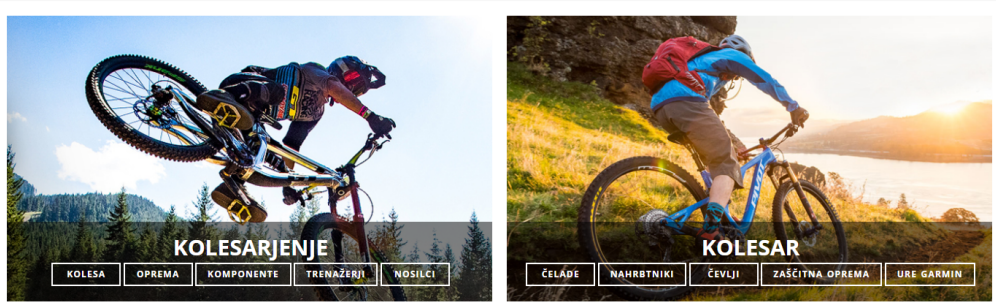

Slika 7: Primera spletne strani z upoštevanjem barvnih kombinacij 


\section{- Vizualni slog}

- Pri tem upoštevamo primerno in razumljivo postavitev statičnih in interaktivnih elementov na zaslonu ali produktu. Uporabniki morajo takoj razumeti pomen posameznih elementov in njihovo uporabnost. Za primer lahko navedemo predvajanje radijskega programa s prikazom radijske postaje in $z$ uporabo gumba za glasnost.

\section{- Velikost interaktivnih elementov}

- Vsi uporabniki in ne samo osebe z različnimi oblikami oviranosti imajo raje velike interaktivne elemente, sploh starejši in majhni otroci. Pri tem je osnova za oblikovanje širina običajnega prsta pri odrasli osebi (Slika 8).

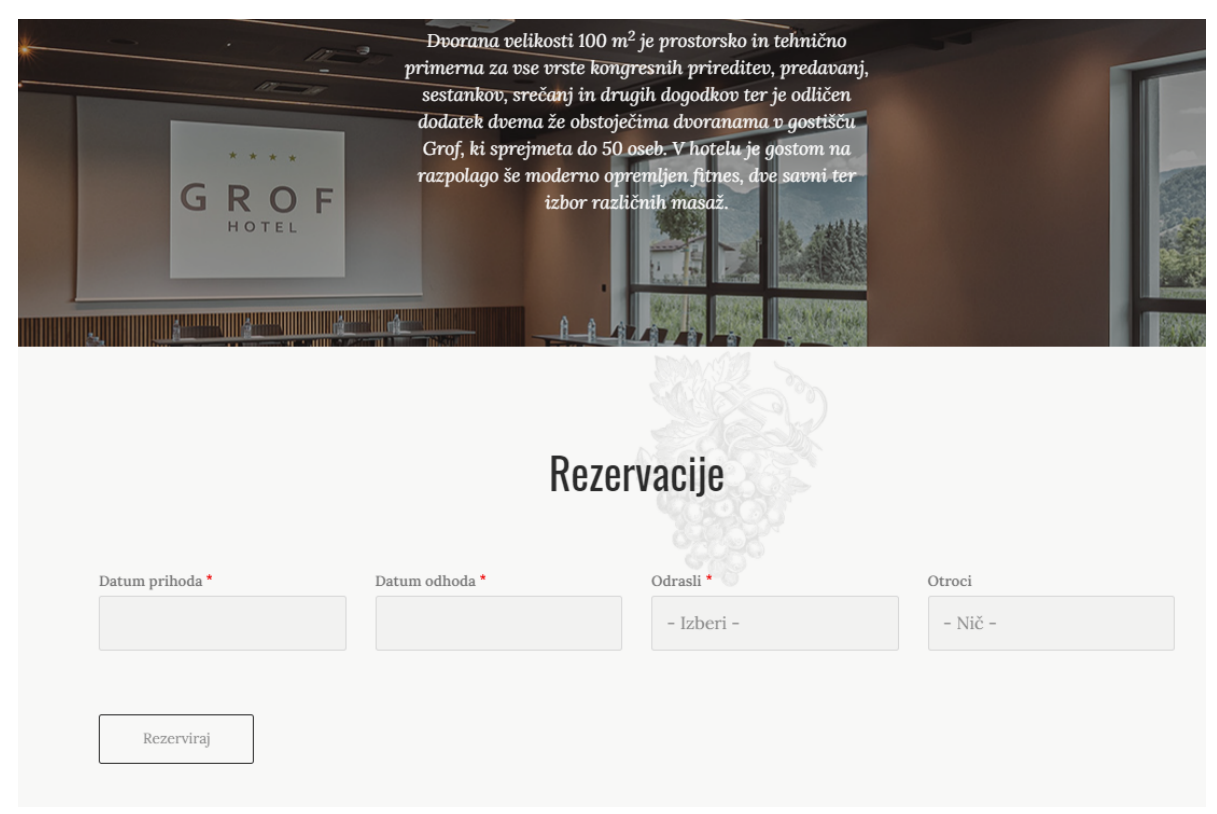

Slika 8: Primer spletne strani z ustreznimi interaktivnimi elementi (vpisna polja)

\section{- Prostor}

- Vsak uporabnik bo imel težave, če bodo elementi postavljeni preveč skupaj, še posebej, če gre za večjo skupino elementov. Med njimi je treba zagotoviti dovolj prostora, da se jih lahko enostavno razbere, razume in po potrebi tudi uporabi (Slika 9). 


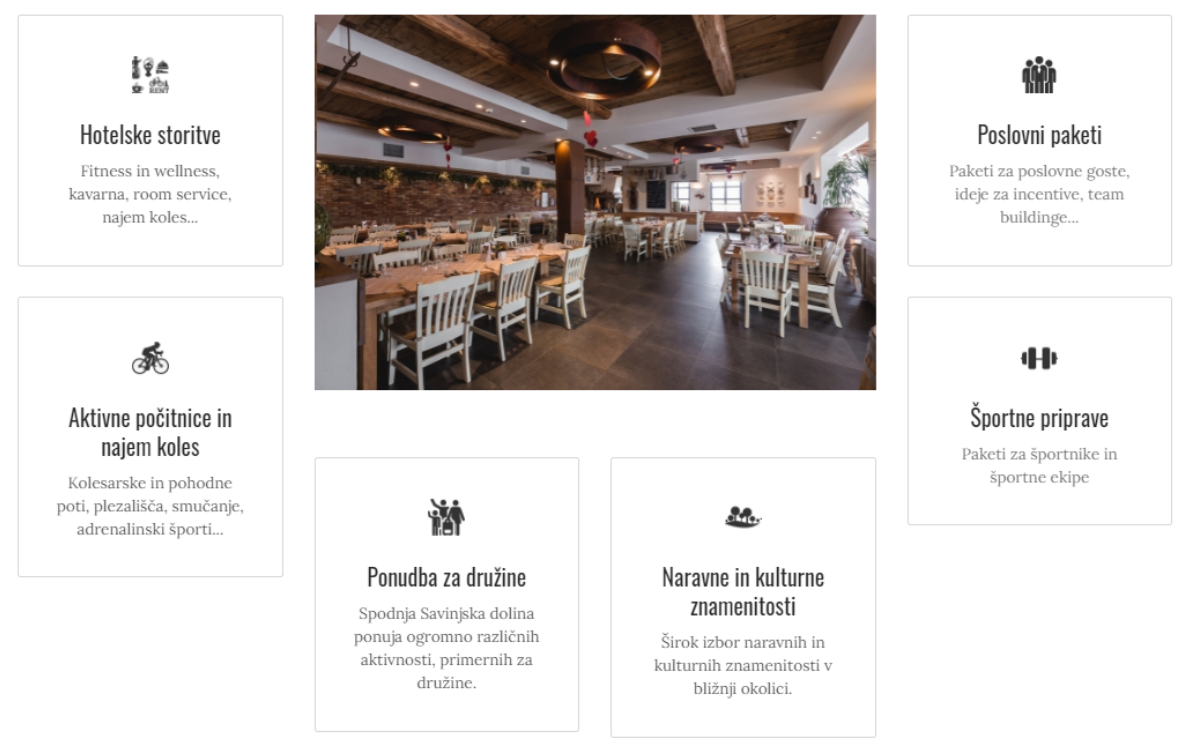

Slika 9: Primer spletne strani z upoštevanjem prostora

\section{- Vidni fokus}

- Vsak element, ki je aktiven, mora biti jasno označen ali uokvirjen, tako da uporabnik v vsakem trenutku ve, kje se nahaja in kaj mora narediti v delu, ki je pred njim (Slika 10).

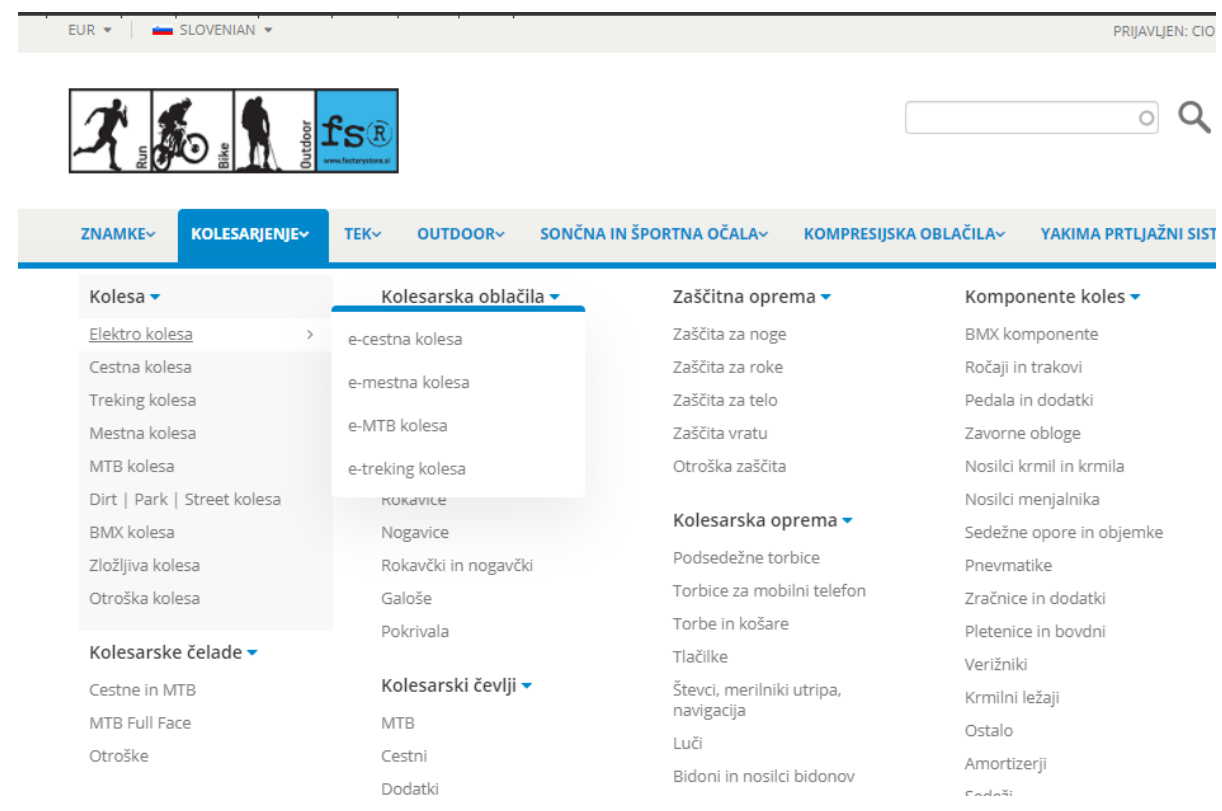

Slika 10: Primer spletne strani z ustreznim fokusom (izbrani meni - kolesarska oblačila) 


\section{- Doslednost}

- Uporabniška izkušnja mora biti pri uporabi produkta vedno dosledno enaka. Dosledni in logični videz pomagata vsem uporabnikom, naj bodo slepi ali videči, da vedo, kaj sledi in kaj morajo narediti (Slika 11).

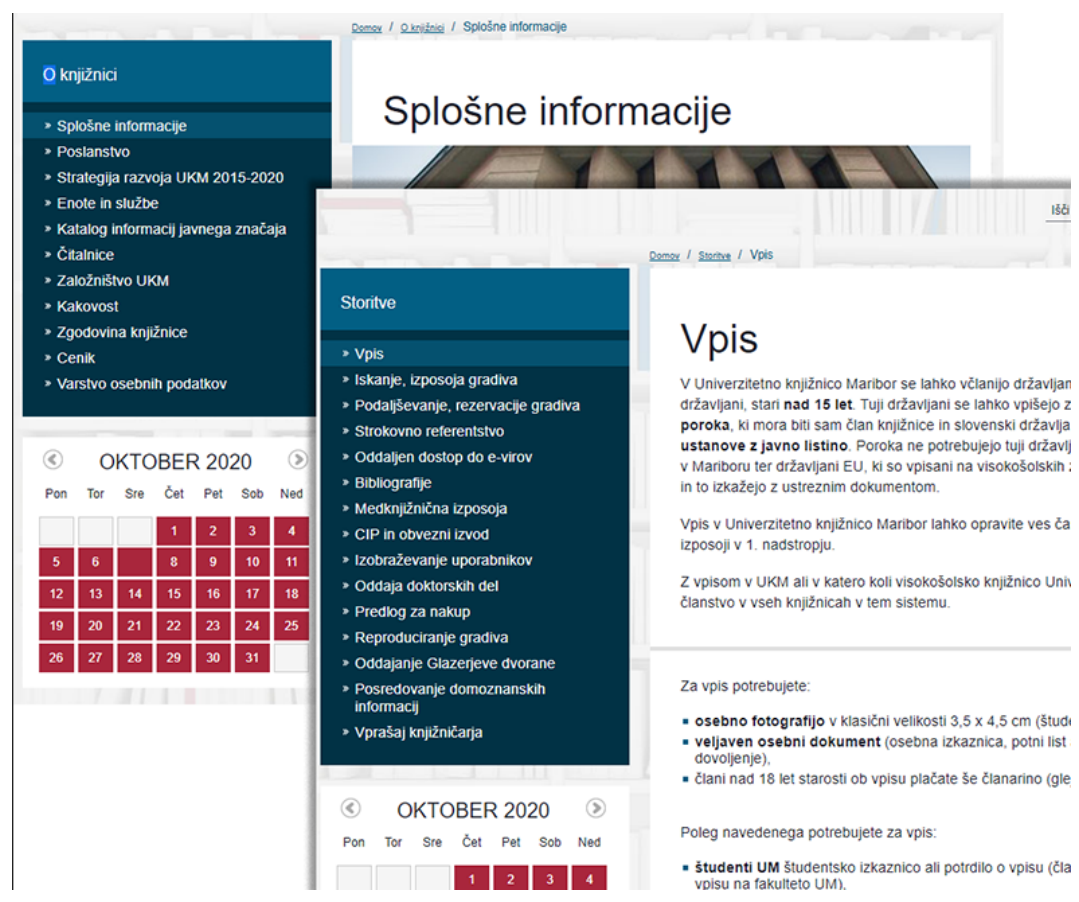

Slika 11: Primer spletne strani z dosledno oblikovanimi vsebinami

\section{- Izbirni elementi}

- Vsak izbirni element naj bo oblikovan tako, da se ga lahko uporabi na več načinov. Na primer, do gumba se lahko navigira $\mathrm{z}$ miško, ustrezno kombinacijo tipk ali s krmilno palico, nato se nanj klikne oziroma se ga aktivira.

\subsubsection{Slike}

Ko začnemo načrtovati in oblikovati slike, moramo najbolj upoštevati zahteve in potrebe slepih, ki slik ne vidijo in pri tem uporabljajo večinoma bralnike zaslonov. Pozorni moramo biti na naslednja elementa načrtovanja:

\section{- Slike besedila}

- Besedilu v obliki slike ali grafike se moramo izogibati. Povečevanje takšnih slik lahkopovzroči, da je besedilo razmazano in slabo razvidno. Prav tako uporabnik ne more spremeniti barve besedila niti jezika, zato ga ne more 
prebrati z bralnikom zaslona. $\mathrm{V}$ tem primeru je primerno uporabiti slike $\mathrm{v}$ formatu SVG (Scalable Vector Graphics) ali vsaj besedilne alternative (Slika 12).

\section{Razpis za nacionalne štipendije programa L'ORÉAL - UNESCO "Za ženske v znanosti" 2021}

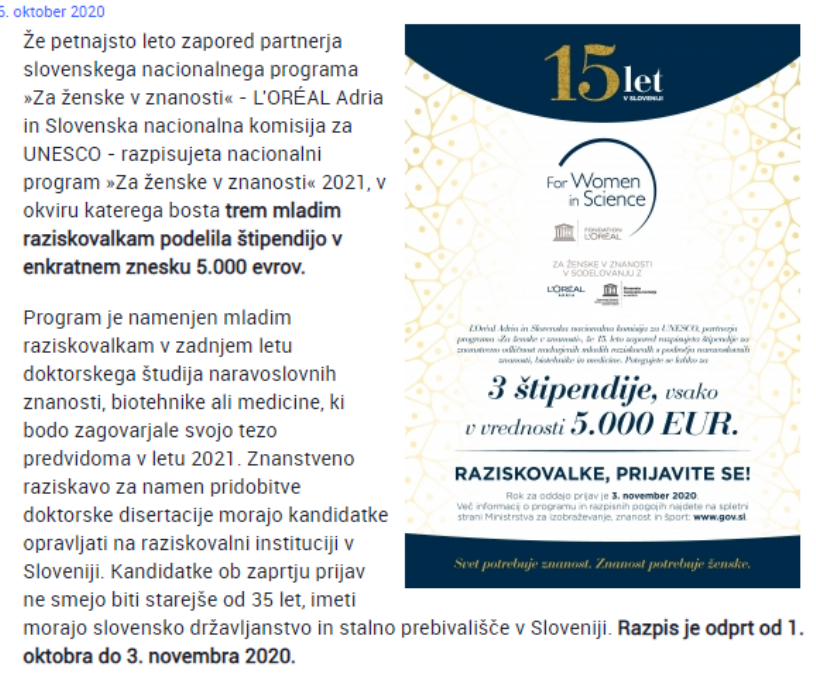
oktobra do 3. novembra 2020.

3 štipendije, ssako v vrednosti $5.000 \mathrm{EUR}$.

RAZISKOVALKE, PRIJAVITE SE!

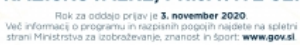

bivališče v Sloveniji. Razpis je odprt od 1 .

Slika 12: Primer spletne strani s sliko v formatu SVG, kjer je besedilo berljivo $\mathrm{z}$ bralniki zaslona.

\section{- Slike ozadja}

- Poskušamo se izogibati slikam ozadja, ki bi ponujale pomembne informacije za izvedbo interaktivnosti, saj jih bralniki zaslona ne upoštevajo. Če pa so slike ozadja vseeno zelo pomembne, poskusimo dodati dostopne alternative za razumevanje, kaj se nahaja v sliki ozadja, in to tako, da ga bo lahko zajel tudi bralnik zaslona.

\subsubsection{Povezave}

Pri načrtovanju povezav, ki jih potrebujemo na spletni strani ali v aplikaciji, se moramo ozirati na naslednje elemente:

\section{- Opisne povezave}

- Povezave in navigacijski pripomočki morajo natančno opisati tarčo ali funkcijo, na katero kaže povezava. Ni primerno, da se uporabi besedilo, kot 
je, na primer, »Klikni tukaj« ali samo beseda »Zbriši«, temveč je treba uporabiti ustrezno besedilo, ki pojasni, kaj se nahaja na tej povezavi. Primer ustreznega besedila je, na primer, »Zbriši besedilo« (Slika 13).

\section{Naročanje kopij člankov}

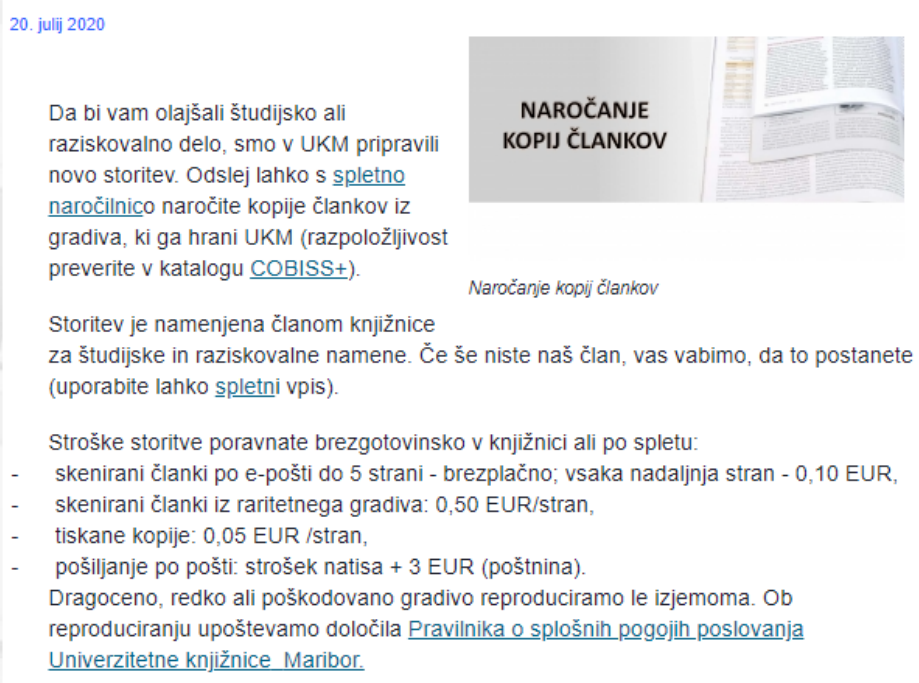

za študijske in raziskovalne namene. Če še niste naš član, vas vabimo, da to postanete (uporabite lahko spletni vpis).

Stroške storitve poravnate brezgotovinsko v knjižnici ali po spletu:

skenirani članki po e-pošti do 5 strani - brezplačno; vsaka nadaljnja stran - 0,10 EUR

skenirani članki iz raritetnega gradiva: 0,50 EUR/stran,

tiskane kopije: 0,05 EUR /stran,

pošiljanje po pošti: strošek natisa + 3 EUR (poštnina).

Dragoceno, redko ali poškodovano gradivo reproduciramo le izjemoma. Ob

reproduciranju upoštevamo določila Pravilnika o splošnih pogojịh poslovanja

Univerzitetne knjižnice Maribor.

Slika 13: Primer spletne strani z opisnimi povezavami

\section{- Povezave na alternativne formate}

- Kadar navigacija vodi v drugačen format ali obliko izpisa, morda biti jasno navedeno, da ta povezava vodi v prikaz drugačnega formata, da se uporabnik ne zmede. To lahko, na primer, uredimo z ikono, ki kaže na »Zunanji dokument v PDF« znotraj aplikacije (Slika 14).

\section{Temperaturno tipalo MWT110}

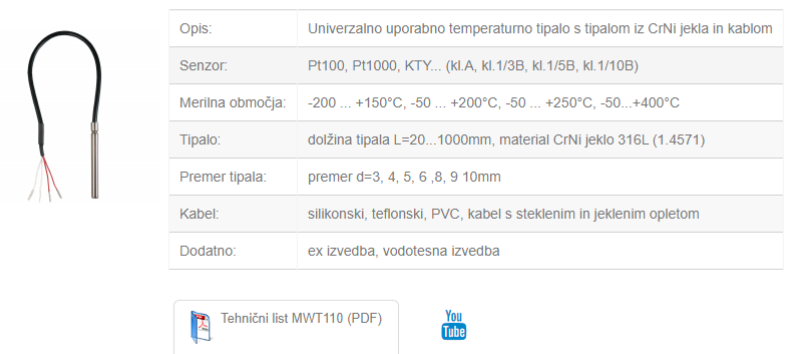

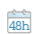

Slika 14: Primer spletne strani s povezavami na alternativne formate 


\section{- Kombiniranje ponavljajočih se povezav}

- Ponavljajoče se povezave, ki kažejo na isti vir, je treba združiti. S tem zmanjšamo število elementov za navigacijo, zmanjšamo zahtevnost za bralnike zaslona in nudimo tudi možnost povečanja velikosti navigacijske tarče.

\subsubsection{Struktura}

Tudi pri strukturi moramo upoštevati določena pravila oblikovanja. Osnovni elementi pri strukturi so naslednji:

\section{- Edinstveni naslov za stran/zaslon}

- Naslov strani/zaslona je običajno prvo, kar uporabniki zasledijo ob uporabi spletnih strani ali produktov in si s tem pomagajo pri navigaciji. Naslovi morajo zato biti jasni in razumljivi ter morajo natančno sporočiti kontekst strani oziroma zaslona (Slika 15).

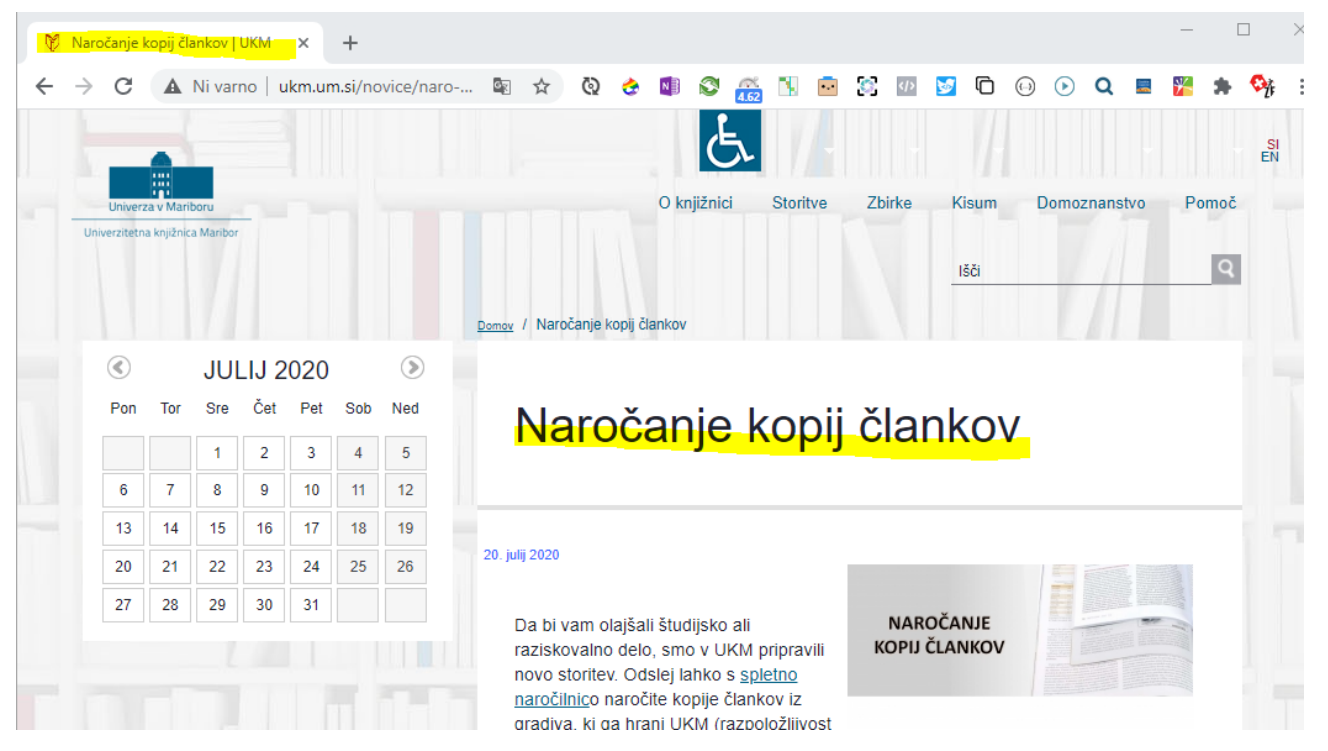

Slika 15: Primer spletne strani z ustreznim naslovom

- Naslovi

- Naslovi morajo biti logično in zaporedno razumljivi ter jasni. Bralniki zaslonov jih uporabljajo za hitro navigacijo skozi besedilo strani ali zaslona. 


\section{- Kontejnerji in oznake}

- Kadar imamo skupine elementov, si pomagamo s kontejnerji, ki morajo natančno in jasno sporočiti, kaj se nahaja znotraj skupine elementov (Slika 16).

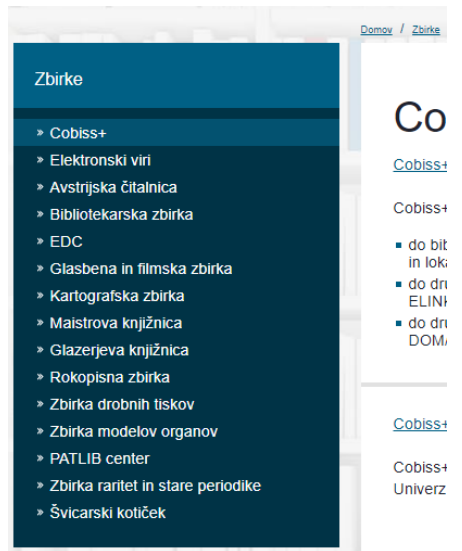

Slika 16: Primer spletne strani z ustrezno navedenimi elementi znotraj kontejnerja

\section{- Združeni elementi}

- Kadar želimo oblikovati več elementov s podobnimi funkcijami ali pomenom, jih poskušamo tudi ustrezno povezati v skupino z eno samo tarčo. S tem povečamo možnost za hitrejšo navigacijo in večje tarče.

S temi elementi smo prikazali samo nekaj osnovnih napotkov, ki jih moramo upoštevati pri oblikovanju spletnih strani in produktov. Za natančnejšo poglobitev v oblikovanje si lahko pomagamo še s smernicami in kriteriji WCAG, ki jih želimo realizirati v našem produktu, opisanimi tudi v prilogi (Priloga 1) [W3C, 2018].

Kakovostne dodatne primere oblikovanja in dodatne informacije o vključitvi dostopnosti najdemo tudi na spletnih straneh Univerze v Cambridgeu - Inclusive Design Toolkit [San Giorgi, 2019]. Te vsebujejo širok nabor dodatnih informacij, s katerimi si lahko oblikovalci dodatno pomagajo pri načrtovanju in oblikovanju produktov in storitev za osebe z različnimi oblikami oviranosti. 


\section{Dobri in slabi primeri oblikovanja glede na dostopnost}

V nadaljevanju predstavljamo šest dobrih in slabih primerov glede na vrsto oviranosti, ki jih lahko uporabimo kot osnovo za splošno oblikovanje in oblikovanje dostopnih produktov ter storitev [A11Portal_A, 2020], in sicer za:

- slabovidne,

- slepe,

- gluhe in naglušne,

- gibalno ovirane,

- dislektike in

- avtiste.

Čeprav so primeri opredeljeni za posamezne skupine oseb z različnimi oblikami oviranosti, je treba pri oblikovanju upoštevati vse zahteve, in to v čim večji meri. Ti primeri so namenjeni temu, da si oblikovalec lažje predstavlja, o čem vse mora razmišljati, ko začne oblikovati, upoštevajoč dostopnost.

Prikazani primeri so sicer priredba primerov, ki se nahajajo na spletni strani A11Portala [A11portal_A, 2020]. Večinoma se tudi opirajo na osnove načrtovanja, ki smo jih opisali v podpoglavju »Načrtovalna področja in pravila oblikovanja v njih«. 


\subsection{Slabovidni - dobri in slabi primeri}

Slabovidni so osebe, ki imajo težave z zajemanjem vizualnih dražljajev. Vzrokov za te težave je lahko več. Mednje spadajo bolezen ali poškodba oči, kratko- ali daljnovidnost, kar zahteva nošenje očal, barvna slepota, slabovidnost, ki je ne moremo enostavno korigirati z očali, in degeneracija oči, zaradi katere vidijo osebe bolj megleno, če omenimo le nekatere.

V glavnem potrebujejo možnost povečevanja, spremembe kontrastov, barv, velikosti fontov in podporo za bralnike zaslonov.

Slika 17 predstavlja osnovne dobre in slabe primere, ki so namenjeni slabovidnim.

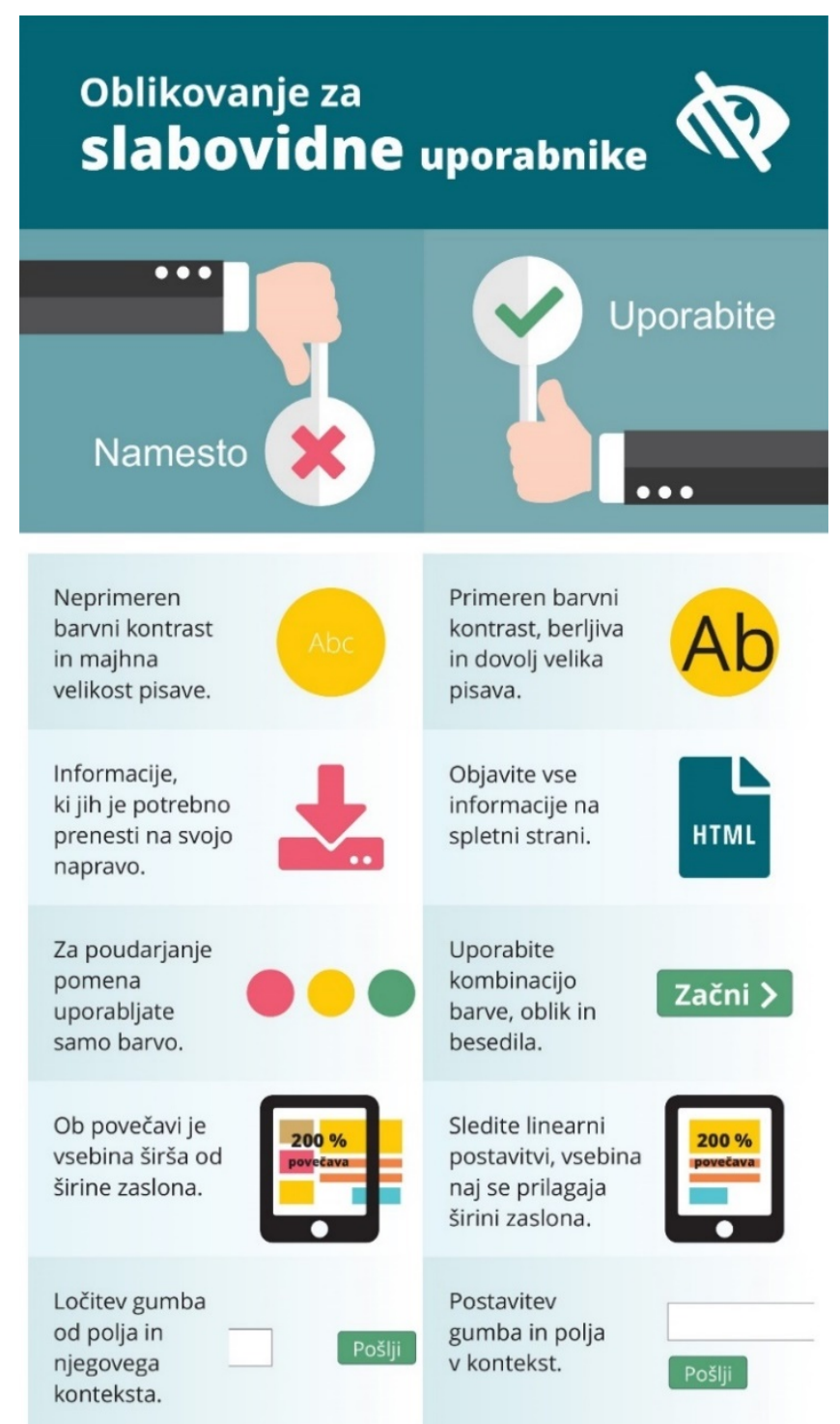

Slika 17: Oblikovanje za slabovidne (dobri in slabi primeri)

[Vir: lasten.] 


\subsection{Slepi - dobri in slabi primeri}

Za slepe, ki večinoma izjemno težko zaznavajo okolico ali pa je sploh ne, je pomembno, da lahko uporabljajo braillov zaslon/tipkovnico, bralnike zaslonov, navigacijo z uporabo tipkovnice in programe za samodejno razpoznavanje govora.

Slika 18 predstavlja osnovne dobre in slabe primere, ki so namenjeni slepim.

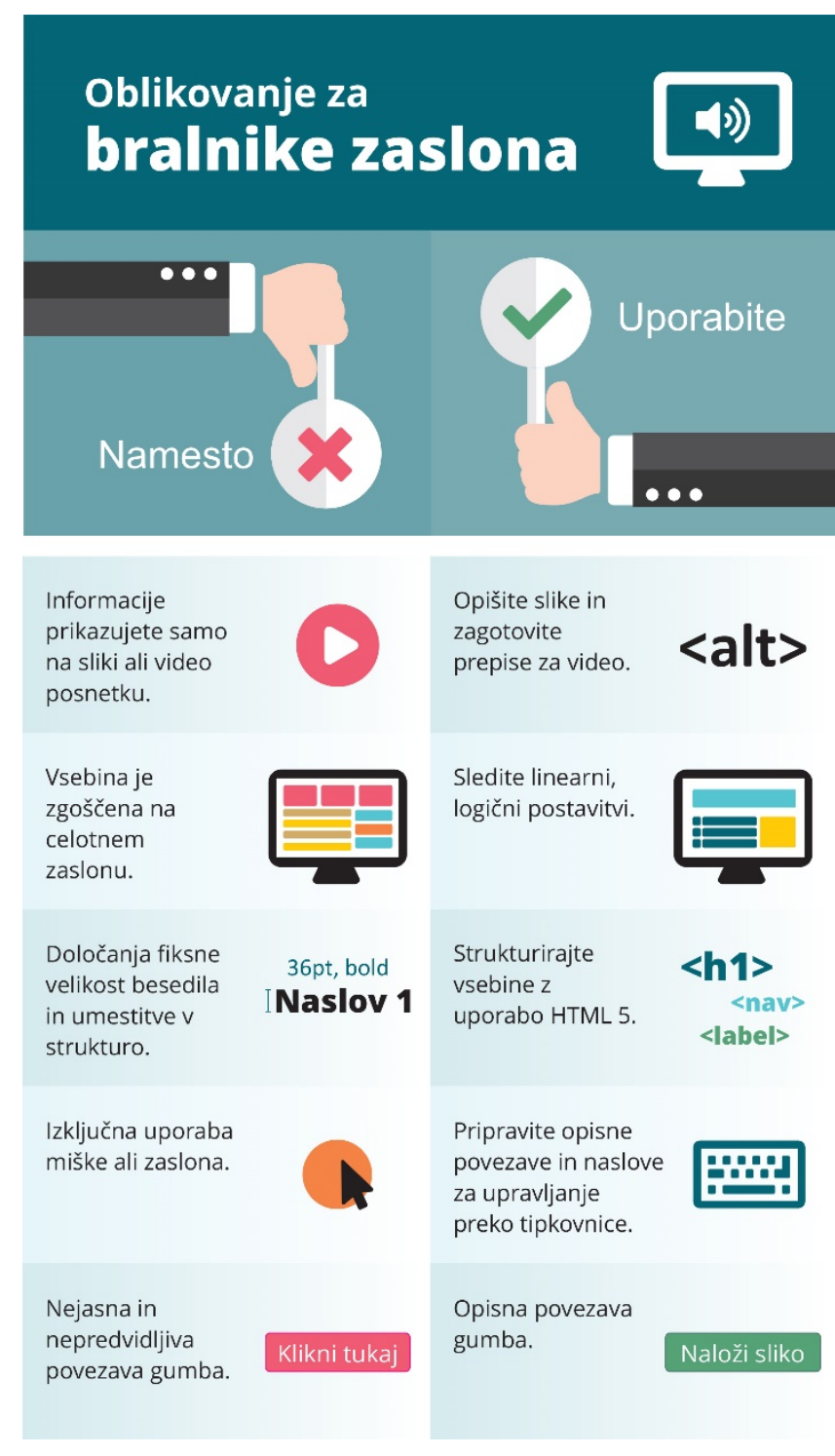

Slika 18: Oblikovanje za slepe (dobri in slabi primeri)

[Vir: lasten.] 


\subsection{Gluhi in naglušni - dobri in slabi primeri}

Za gluhe in naglušne je značilno, da imajo težave pri poslušanju zvokov. Vzroki za to so lahko različni, denimo bolezen ali poškodba, ki je vplivala na sluh, slabšanje zaznavanja zvokov, ki zahteva uporabo slušnih aparatov, šum v ušesu (tinitus), ki onemogoča jasno poslušanje, ter popolna izguba sluha.

Gluhi in naglušni potrebujejo predvsem podnapise $\mathrm{v}$ video posnetkih, znakovni jezik namesto pisne besede, ker je to njihov prvi jezik, in transkripte govorjenih besedil.

Slika 19 predstavlja osnovne dobre in slabe primere, ki so namenjeni gluhim in naglušnim.

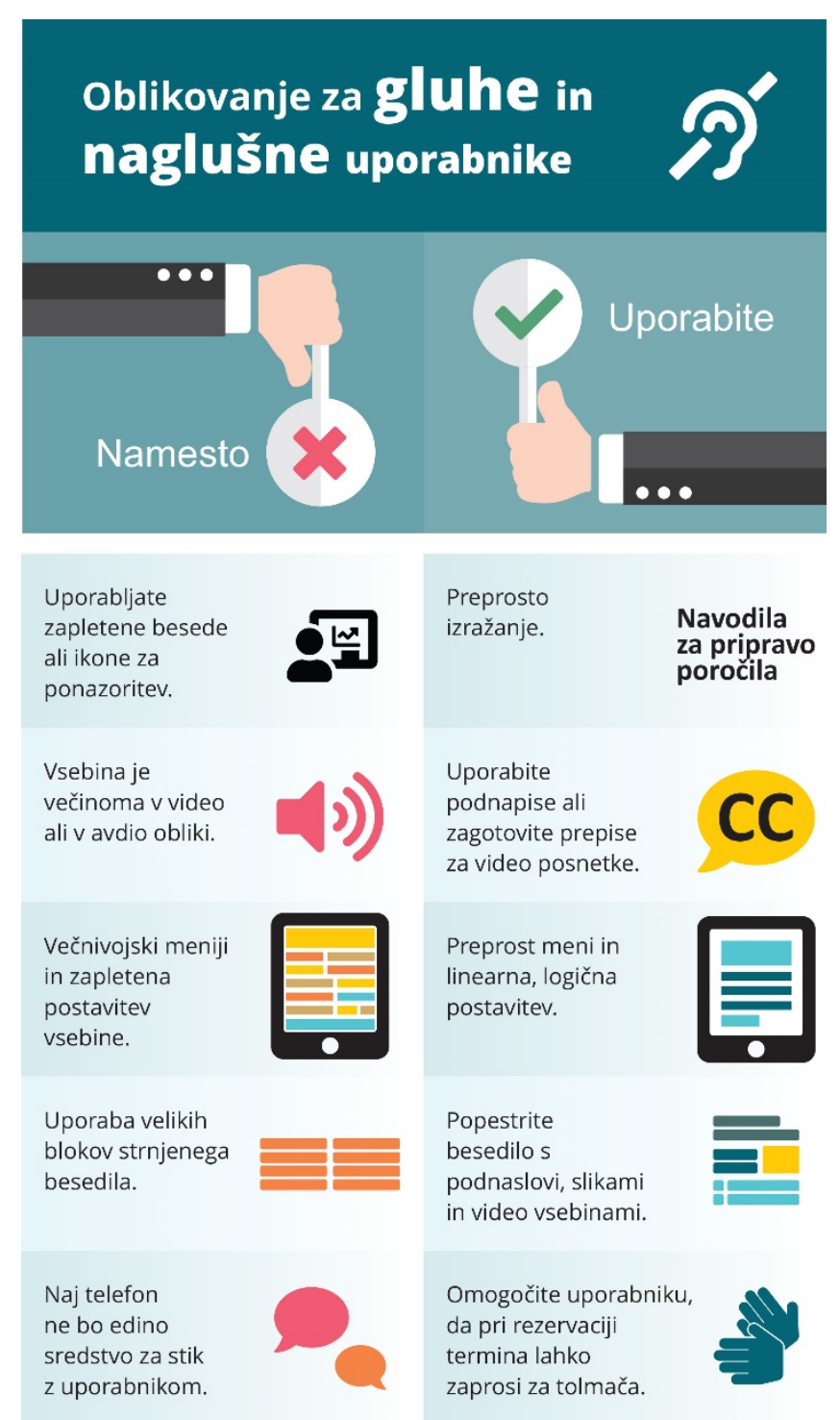

Slika 19: Oblikovanje za gluhe in naglušne (dobri in slabi primeri)

[Vir: lasten.] 


\subsection{Gibalno ovirani - dobri in slabi primeri}

Za gibalno ovirane je značilno, da težko uporabljajo svoje ude ali telo pri interakciji z digitalnimi pripomočki ali pa jih sploh ne morejo. Vzroki so lahko, da ne morejo česa dvigniti ali nositi, $z$ rokami ne morejo prijemati vhodnih naprav, zaradi bolezni ali poškodbe mišice ne delujejo primerno, zaradi bolezni so ovirani premiki telesa ali mišic ali pa imajo delno paralizo telesa.

Za svoje delo potrebujejo predvsem senzorje (za gibanje, oči, telo), krmilne palice, prirejene tipkovnice in sisteme za razpoznavanje govora.

Slika 20 prikazuje osnovne dobre in slabe primere, ki so namenjeni gibalno oviranim.

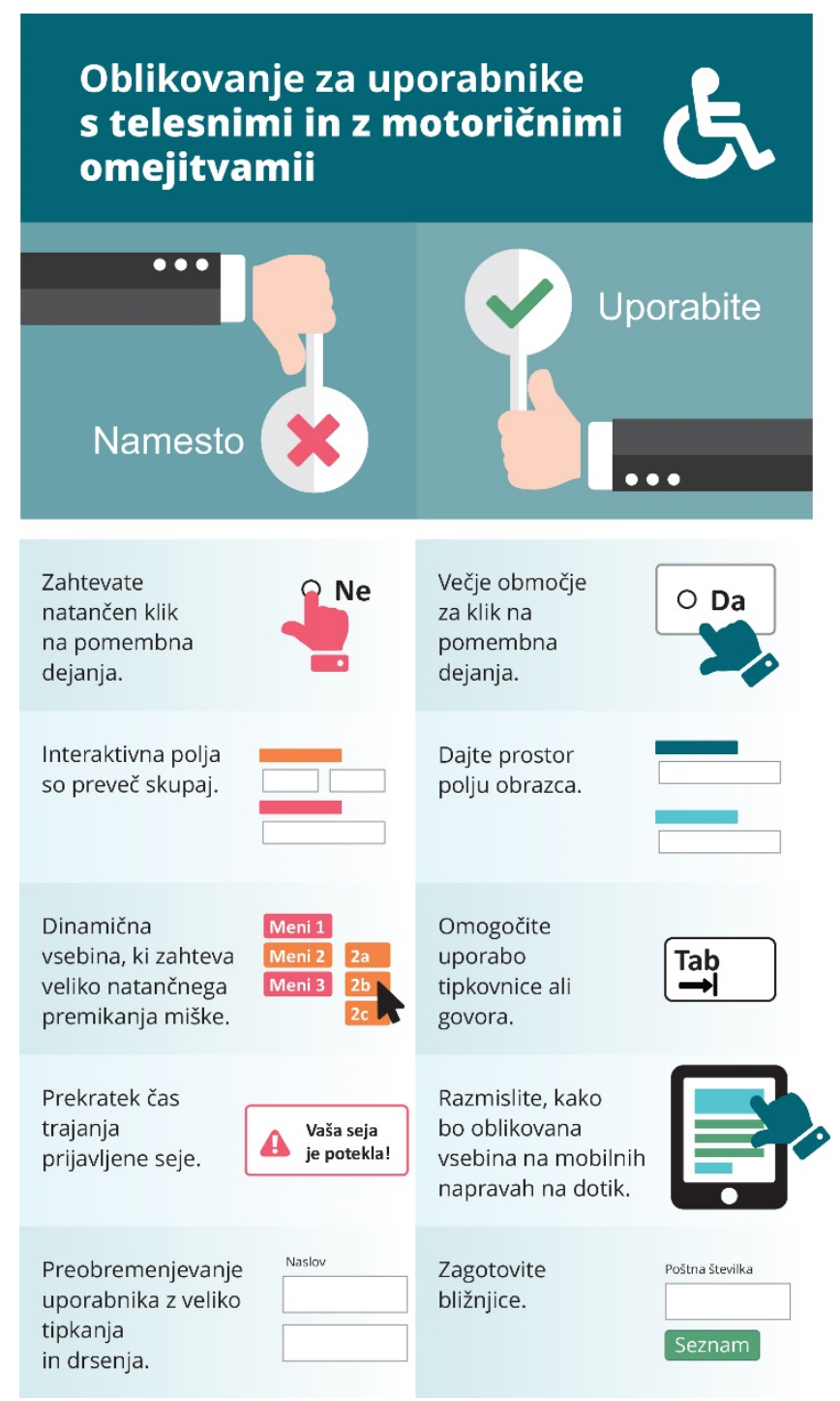

Slika 20: Oblikovanje za gibalno ovirane (dobri in slabi primeri)

[Vir: lasten.] 


\subsection{Dislektiki - dobri in slabi primeri}

Za dislektike je značilno, da nimajo radi nejasnih in nedoslednih informacij. Prav tako ne marajo presenečenj ali informacij, ki vsebujejo sarkazem, metafore ali ironijo. Zanje ni primerno, da je besedilo izjemno dolgo in brez prave strukture.

Kot pripomočke najpogosteje uporabljajo snemalnike zvokov in samodejno razpoznavo govora.

Slika 21 predstavlja osnovne dobre in slabe primere, ki so namenjeni dislektikom.

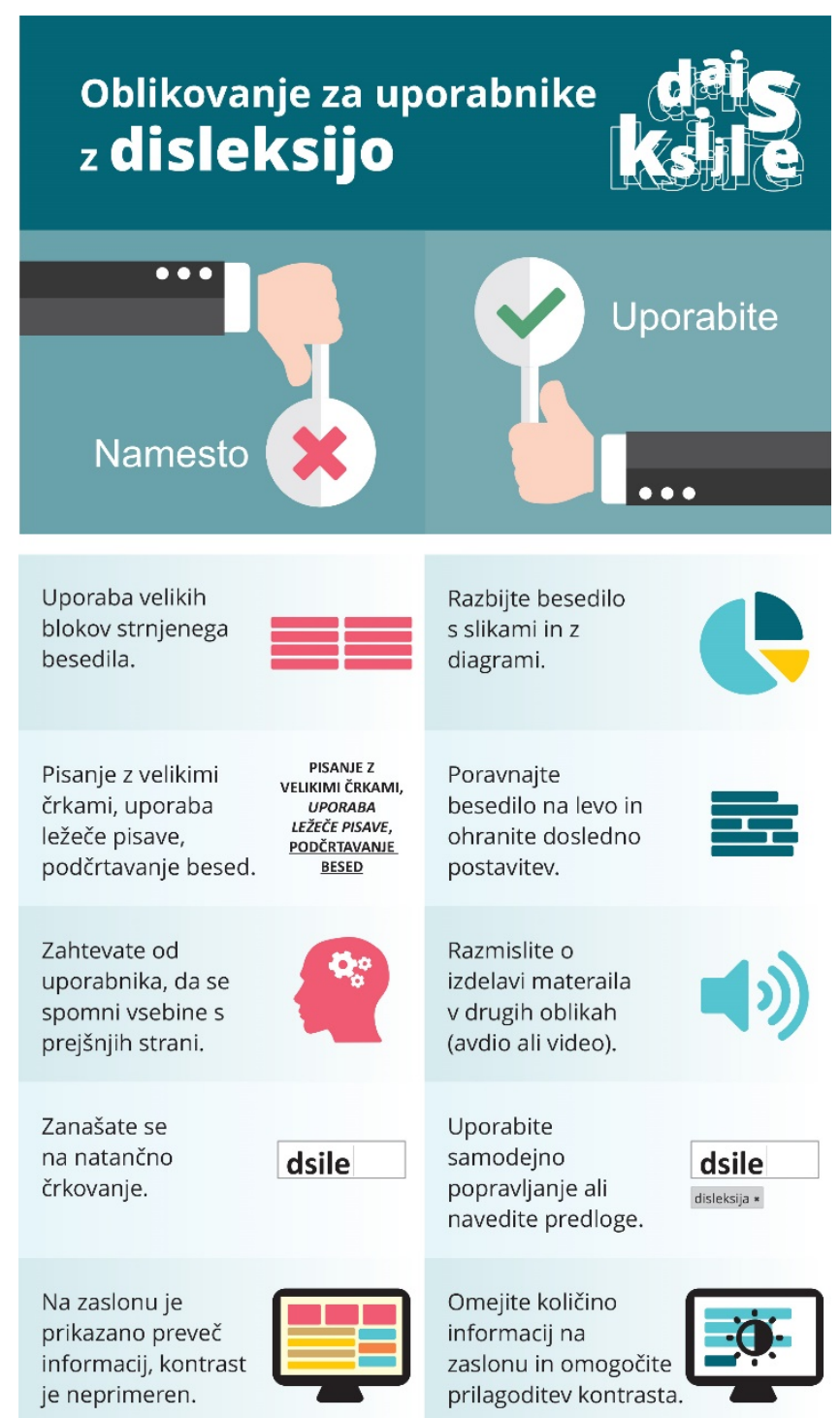

Slika 21: Oblikovanje za dislektike (dobri in slabi primeri)

[Vir: lasten.] 


\subsection{Avtisti - dobri in slabi primeri}

Za avtiste je značilno, da se težje soočajo s situacijami, kjer morajo razumeti in procesirati informacije. Težave imajo zaradi majhne tolerance do prekomerne obremenitve, zmanjšane sposobnosti za reševanje problemov, težav s kratkotrajnim spominom in koncentracijo.

Radi uporabljajo digitalno tehnologijo, ki omogoča vedno enako in dosledno vodenje postopka. Prav tako je zanje primerna tudi uporaba snemalnikov zvoka s samodejno razpoznavo govora in uporabo avatarjev, ki se vedno na predvidljiv in enak način odzovejo.

Slika 22 prikazuje osnovne dobre in slabe primere, ki so namenjeni avtistom.

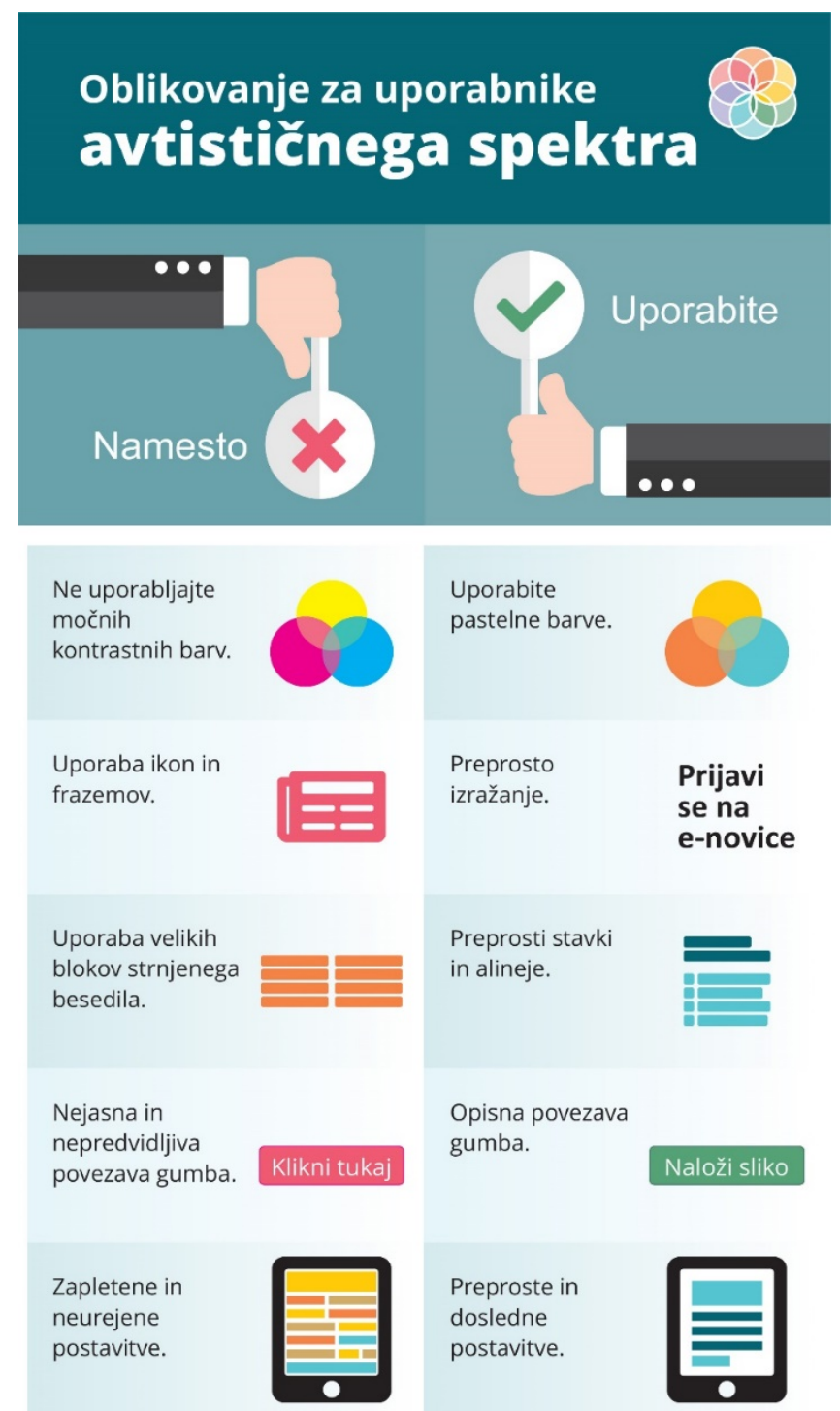

Slika 22: Oblikovanje za avtiste (dobri in slabi primeri)

[Vir: lasten.] 


\section{Primeri zaznanih neskladnosti in njihova odprava}

Prikazana sta dva primera, pri katerih je mogoče s spremembo kode HTML in CSS zagotoviti skladnost. V prvem gre za odpravo premajhnega kontrasta pri posameznem elementu, $v$ drugem pa $z$ dodajanjem atributa ALT omogočimo dostopnost povezave za uporabnike s posebnimi bralniki.

V obeh primerih z relativno enostavnimi prilagoditvami močno povečamo dostopnost.

\section{Kontrast}

Za preverjanje kontrasta so v brskalnikih na voljo razširitve (npr. Lighthouse za Google Chrome ipd.), ki pomagajo pri določanju ustreznega kontrasta. Minimalni kontrast je sicer $4,5: 1$. Avtomatizirano orodje je zaznalo premajhen kontrast na koledarju (sploh za vikende, kjer je uporabljena drugačna barva). Pregled uporabljene CSS-kode (z dodatkom Lighthouse) pokaže, da je kontrast komaj 2,12:1 (Slika 23).

Kontrast smo popravili s spremembo barve. Po preverjanju z orodjem smo ugotovili, da smo dosegli kontrast 8,89, kar potrjuje tudi slika (Slika 24). 


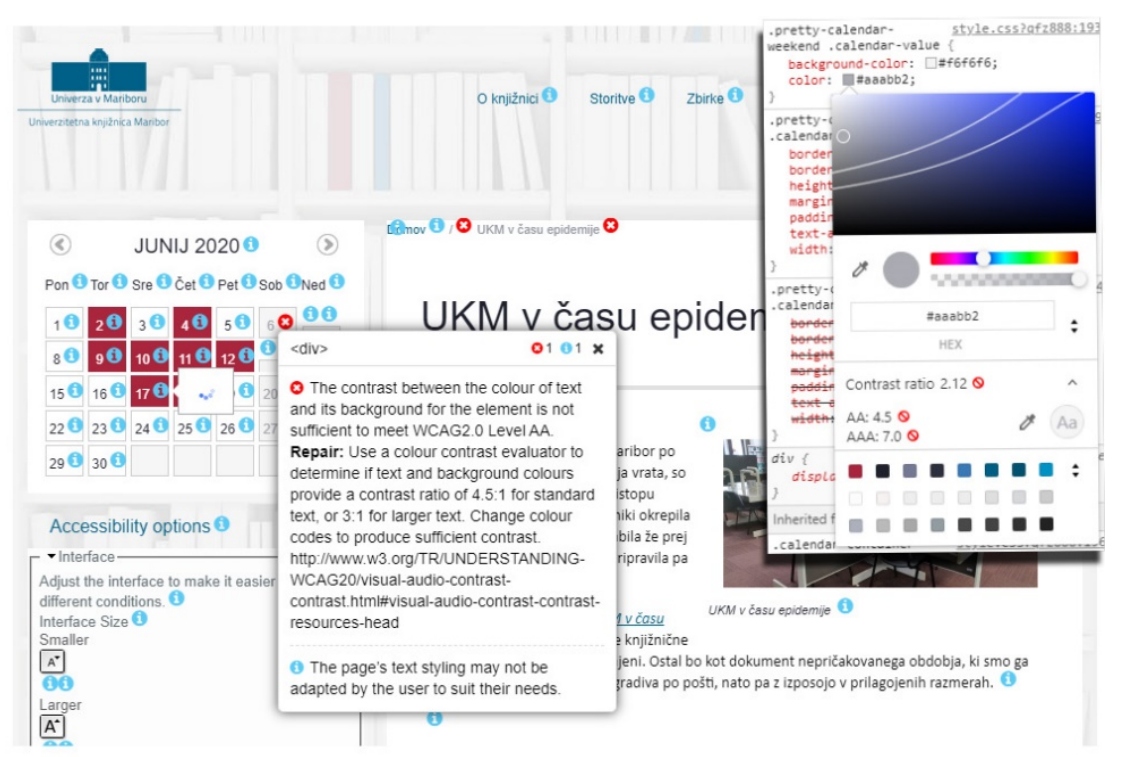

Slika 23: Kontrast pred spremembo

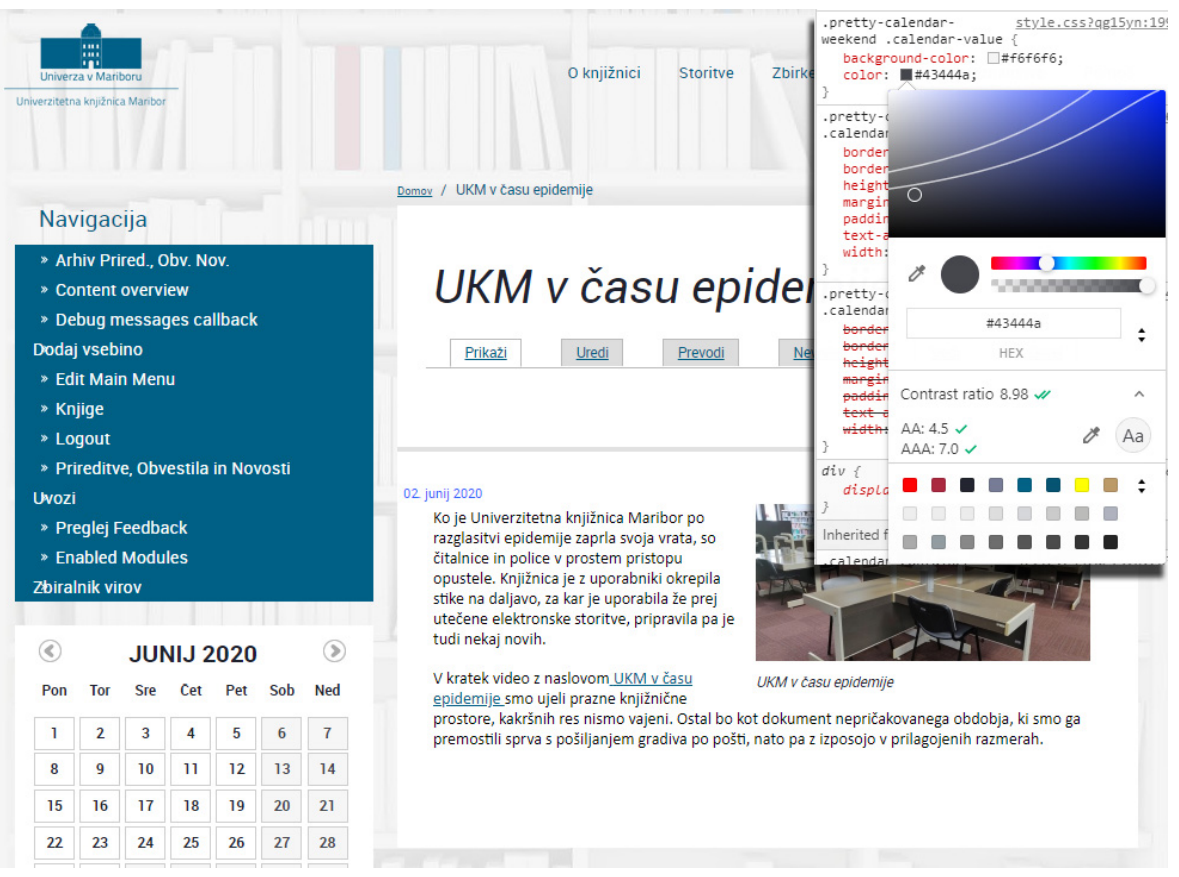

Slika 24: Kontrast po spremembi

\section{HTML-atribut ALT}

Dodajanje atributa ALT za slike je odvisno od platforme, na kateri je zgrajena spletna stran, in od vrste elementa. Nekateri elementi so dosegljivi v uporabniškem vmesniku, do katerega dostopajo uredniki strani, drugi so del predlog ali programske kode, kjer se zahteva sodelovanje programerja. 
Slika na spletni strani Zgodovina knjižnice je brez besedila za povezavo (angl. link) na povečano različico slike, istočasno pa je vsebina povezave slika, kjer ni vnesena vrednost za atribut ALT (Slika 25).

Sliki, ki je znotraj povezave, smo zato dodali in opisali atribut ALT. Tako uporabnik, ki dostopa do strani prek bralnika zaslona, ve, kam ga bo pripeljala povezava, čeprav ne vidi vsebine slike (Slika 26).

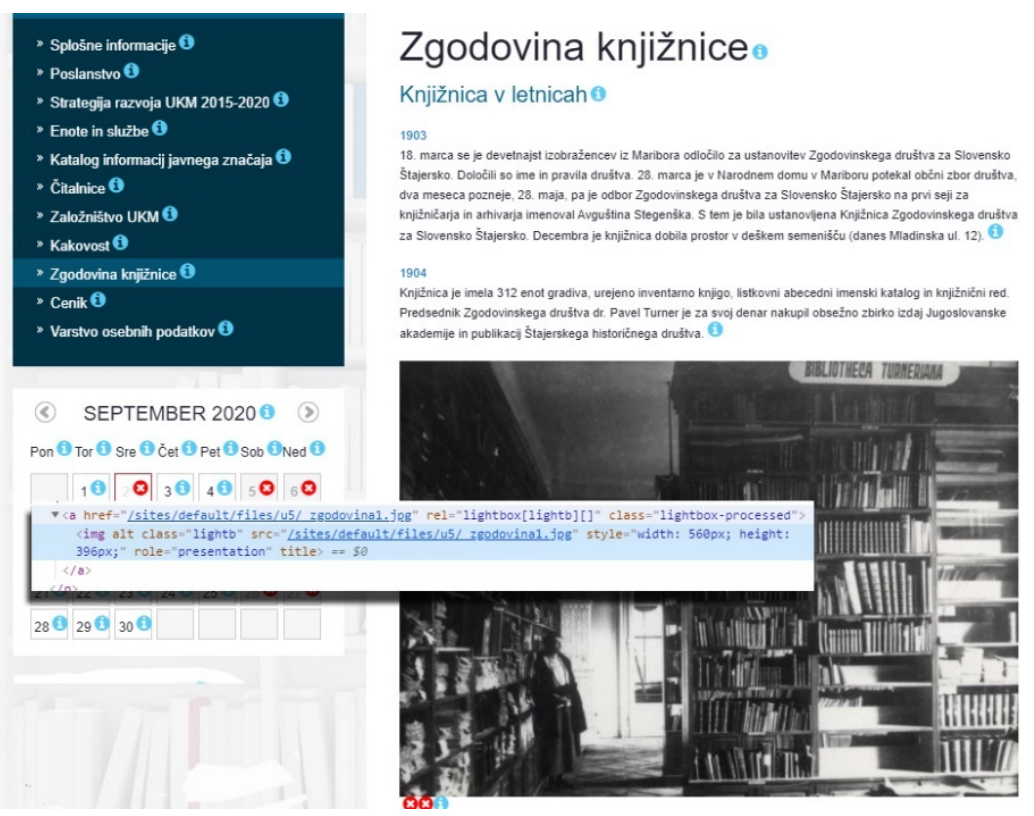

Slika 25: Pomanjkljivi ALT pred spremembo

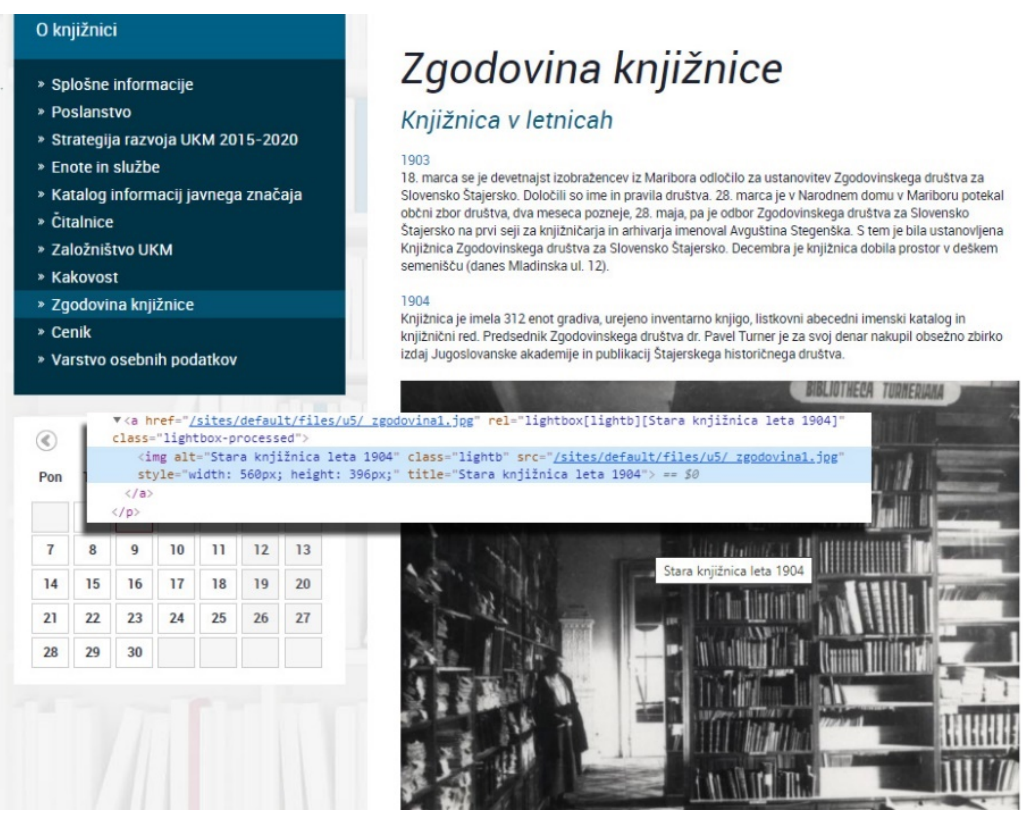

Slika 26: Ustrezni opis ALT po spremembi 


\section{$7 \quad$ Načini ocenjevanja in preverjanja dostopnosti spletnih strani ter aplikacij}

\subsection{Uvod v ocenjevanje}

Ocenjevanje produktov, storitev in spletnih strani ni tako enostavno, kot se zdi na prvi pogled. Sploh preverjanje spletnih portalov, ki vsebujejo na tisoče spletnih strani, je lahko zelo zamuden proces. Ocenjevalci zato običajno preverjajo samo nekatere naključne in najpomembnejše spletne strani, dele aplikacij ali produktov, ki so ključnega pomena. $\mathrm{Na}$ podlagi ocenitve nekaterih delov lahko potem izvajalec izdela šablono ali predlogo, ki je osnova za vse ostale dele spletnega portala ali produkta. Vsekakor je nujno potrebno kakršno koli ocenjevanje, tako $\mathrm{z}$ vidika uporabnosti ter dostopnosti že $\mathrm{v}$ fazi načrtovanja in implementacije kot tudi na koncu, ko so spletne strani, aplikacije ali produkti že na tržišču.

Da bi se izognili kasnejšim neprijetnim presenečenjem zaradi dokazljive nedostopnosti, je zelo pomembno, da se načela dostopnosti upoštevajo že takoj na začetku razvoja in se uporabijo učinkovite šablone ali predloge avtorskih orodij, ki že v osnovi upoštevajo načela dostopnosti.

$\mathrm{Na}$ voljo so tudi različna spletna ali aplikativna orodja za hitro preverjanje spletnih strani, aplikacij in produktov, vendar nobeno orodje samo zase ne more določiti v celoti, ali produkti oziroma storitve $\mathrm{v}$ celoti ustrezajo standardom dostopnosti. Za ustrezno dokončno odločitev o tem, kakšna je dostopnost, potrebujemo še vedno izkušenega 
strokovnjaka s področja dostopnosti, ki še ročno oceni posamezne kriterije in načela. Izkušeni strokovnjak tudi izdela poročilo in določi ustrezno raven dostopnosti, če je ta dosežena.

Po navodilih W3C [W3C_A, 2020] postopek ocenjevanja poteka v več korakih in $\mathrm{z}$ različnimi izvajalci (Tabela 3 ).

Tabela 4: Postopek ocenjevanja in izvajalci posameznega koraka ocenjevanja

\section{KORAK OCENJEVANJA}

\begin{tabular}{|c|c|}
\hline 1. Hitro preverjanje & $\begin{array}{l}\text { vodstvo, uredniki, oblikovalci, vpisovalci, } \\
\text { programerji }\end{array}$ \\
\hline $\begin{array}{l}\text { 2. Diagnostično preverjanje } z \text { uporabo } \\
\text { programskih orodij }\end{array}$ & $\begin{array}{l}\text { uredniki, oblikovalci, vpisovalci, programerji, } \\
\text { strokovnjaki za dostopnost }\end{array}$ \\
\hline 3. Končno preverjanje strokovnjakov & strokovnjaki za dostopnost \\
\hline 4. Poročanje & strokovnjaki za dostopnost \\
\hline 5. Priprava izjave o dostopnosti & strokovnjaki za dostopnost \\
\hline
\end{tabular}

V nadaljevanju sledi podrobnejša razlaga potrebnih korakov.

\subsection{Hitro preverjanje}

Hitro preverjanje je primerno za vse, tudi za tiste, ki ne vedo ničesar o dostopnosti, in sicer, še preden začnemo resno testirati z orodji in ročnim ocenjevanjem.

Ta del zajema samo nekatere vidike dostopnosti in je namenjen samo temu, da na hitro ocenimo, ali ustreza spletna stran, aplikacija ali produkt vsaj osnovnim zahtevam, preden se poglobimo v podrobnejše ocenjevanje.

Pri hitrem preverjanju preverjamo naslednje točke [WC3_B, 2020] [Tabela 4]: naslov, alternativno besedilo za slike, besedilo, interakcijo in splošne vidike, kot sta premikanje in utripanje, multimedijske (video in avdio) alternative ter osnovno strukturo. 
Tabela 5: Točke za hitro preverjanje

\begin{tabular}{|l|l|}
\hline ELEMENT PREVERJANJA & KAJ PREVERIMO \\
\hline Naslov & $\begin{array}{l}\text { Naslov ustreza vsebini in jo na kratko opisuje? } \\
\text { So naslovi različni? }\end{array}$ \\
\hline Alternativno besedilo za slike & $\begin{array}{l}\text { Ima vsaka slika alternativno besedilo, ki jo pojasnjuje (značka ALT } \\
\text { na spletni strani HTML)? }\end{array}$ \\
\hline $\begin{array}{l}\text { Naslovi in podnaslovi v } \\
\text { besedilu }\end{array}$ & $\begin{array}{l}\text { Obstaja vsaj en naslov za vsebino? } \\
\text { Je besedilo naslovov ustrezno označeno kot »naslovi«? } \\
\text { So naslovi in podnaslovi ustrezno strukturirani? }\end{array}$ \\
\hline Kontrastno razmerje & $\begin{array}{l}\text { Je kontrastno razmerje med barvo besedila in ozadja vsaj 4,5: } 1 \\
\text { glede na običajno velikost besedila? }\end{array}$ \\
\hline Povečanje besedila & $\begin{array}{l}\text { Lahko povečamo ali zmanjšamo velikost besedila, fontov, ne da bi } \\
\text { pri tem pokvarili berljivost in navigacijo? }\end{array}$ \\
\hline $\begin{array}{l}\text { Uporaba tipkovnice brez } \\
\text { miške }\end{array}$ & $\begin{array}{l}\text { Lahko uporabljamo tabulatorsko tipko <Tab>? } \\
\text { Lahko za večino funkcij uporabimo tipke na tipkovnici (premiki } \\
\text { kazalca, povečanje, pomanjšanje ...), ne da bi potrebovali miško? }\end{array}$ \\
\hline Vidni fokus & $\begin{array}{l}\text { Je vidni fokus jasno razviden s poudarjenimi elementi na zaslonu? } \\
\text { Lahko vidimo, kje se nahajamo v spustnih menujih? } \\
\text { Je jasno razvidno, kje so povezave v besedilu ali na zaslonu? }\end{array}$ \\
\hline $\begin{array}{l}\text { Vpisna polja in njihove } \\
\text { oznake }\end{array}$ & $\begin{array}{l}\text { So vpisna polja dostopna tudi s tipkovnico? } \\
\text { Je vsako vpisno polje ustrezno označeno z besedilom oziroma } \\
\text { interaktivnimi gumbi? }\end{array}$ \\
\hline Napake & $\begin{array}{l}\text { So informacije o napakah jasne in razumljive? } \\
\text { Produkt zna preprečevati napačne vnose? } \\
\text { Informacije o rešitvi napak hitro najdemo? }\end{array}$ \\
\hline Multimedija (video in avdio) & $\begin{array}{l}\text { Se informacije premikajo ali utripajo na zaslonu? } \\
\text { Ce utripajo, ali utripajo več kot trikrat na sekundo in ali zajemajo } \\
\text { pri tem velik del zaslona? }\end{array}$ \\
\hline $\begin{array}{l}\text { So na voljo primerni podnapisi za video, avdio opis za video in } \\
\text { transkript za avdio? }\end{array}$ \\
$\begin{array}{l}\text { Besedilo ustreza strukturi? Besedilo poglavja ustreza naslovu? So } \\
\text { podnaslovi v primernem zaporedju? }\end{array}$ \\
\hline Premikanje in utripanje
\end{tabular}

Ko smo izpeljali takšno hitro preverjanje dostopnosti, lahko svoja opažanja zapišemo in pri tem poskusimo tudi narediti posnetek zaslona (angl. Screenshot), če je to mogoče, ter ga primerno opišemo.

Vsa svoja opažanja nato pošljemo na naslov, ki je naveden v Izjavi za dostopnost, ki jo mora imeti vsako javno spletišče. Če ne gre za javno spletišče, poiščemo kontaktni e-naslov podjetja in jim pošljemo svoja opažanja z željo, da bi čim prej odpravili manjkajoče elemente ali pomanjkljivosti. 


\subsection{Preverjanje $z$ uporabo orodij}

Na voljo je več kot 100 različnih programskih orodij za preverjanje spletnih strani, aplikacij in produktov glede na dostopnost oziroma določene posamezne kriterije dostopnosti. Nekateri so prosto dostopni, drugi pa plačljivi.

Ti testi so lahko zelo v pomoč, saj z njimi zelo hitro dobimo prvi vtis o ravni dostopnosti, vendar se moramo zavedati, da nikoli ne morejo preveriti vseh kriterijev dostopnosti. Še posebej to velja za zelo specifične kriterije dostopnosti, kot je ustreznost vsebine besedila. Nekaterih drugih kriterijev, kot so kriteriji za vnašanje podatkov s tipkovnico, prav tako ne moremo samodejno in programsko preverjati, zato zahtevajo ročno preverjanje.

V prilogi 2 [Priloga 2] je naveden primerjalni seznam, ki pokaže, katere kriterije lahko preverimo $z$ orodji in katere samo ročno.

V prilogi 3 [Priloga 3] je na voljo seznam nekaterih orodij s povezavami nanje. Z njimi lahko najdemo določene pomanjkljivosti, vendar ne vseh. Tako lahko prihranimo veliko časa in povečamo učinek ocenjevanja. Prav tako nam ta orodja pomagajo pri implementaciji tako, da lahko hitro preverimo, ali trenutna različica spletne strani, aplikacije ali produkta ustreza dostopnosti.

Med temi orodji so nekatera tudi takšna, ki ocenjevalca usmerjajo, kdaj naj uporabi ročno ocenjevanje posameznega kriterija in kako naj to izvede. Nekatera orodja testirajo eno samo spletno stran, medtem ko druga lahko preverijo celotno spletišče. Določena orodja lahko integriramo v svoja razvojna okolja ali avtorska orodja ali celo v sisteme za upravljanje vsebin (angl. Content Management System - CMS).

Vendar moramo biti zelo previdni, saj nekatera orodja ne dajo pravilnih rezultatov. Zaradi tega moramo ocenjevati spletne strani ali aplikacije s previdnostjo in $z$ natančnejšim preverjanjem. V ta namen je praktično uporabljati pripomoček za izbiranje orodij, ki so ga pripravili v okviru W3C in se nahaja na vrhu priloge 3 [Priloga 3]. S tem pripomočkom lahko filtriramo orodja in poiščemo tisto, ki ga potrebujemo za naš namen. 


\subsection{Končno preverjanje strokovnjakov}

Za končno preverjanje, ki zajema tudi ročno preverjanje, se lahko med drugim uporabi hitro hevristično ocenjevanje, ki smo ga pripravili in uporabili na Inštitutu za medijske komunikacije Fakultete za elektrotehniko, računalništvo in informatiko Univerze v Mariboru v sodelovanju z izobraževalno ustanovo B2, d. o. o., in Medicinsko univerzo v Gradcu, Avstrija [Debevc, 2015].

S to metodo lahko ob pomoči 20 udeležencev, strokovnjakov z ustrezno organizacijo in vodenjem, celo v enem dnevu učinkovito preverimo vseh 50 kriterijev uspešnosti za nekaj spletnih strani, saj vsak udeleženec preveri samo pet kriterijev. Teh 20 udeležencev je razdeljenih $\mathrm{v}$ dve skupini, tako da vsaka preveri vseh 50 kriterijev, nato pa med seboj primerjajo rezultate. Kjer se razlikujejo, se jih nato ponovno preveri z vodjo ocenjevanja in se skupaj dogovorijo o končni oceni za določen kriterij.

\subsubsection{Stopnja potrebne strokovnosti}

Za to metodo ocenjevanje je zaželeno, da ima vsak udeleženec, ki ocenjuje spletne strani, aplikacijo ali produkt vsaj osnovno predznanje o ocenjevanju s standardom ETSI EN 301 549 in da pozna osnove smernic WCAG. Prav tako je zaželeno vsaj osnovno znanje o tem, kakšne so zahteve in potrebe oseb z različnimi oblikami oviranosti, da pozna osnovne tehnologije, ki so potrebne zanje, in vidike različnih prilagoditev zanje glede na stopnjo in zahtevnost oblik oviranosti. Zaželeno je, da so med njimi tudi strokovnjaki, ki spadajo med osebe $z$ različnimi oblikami oviranosti.

\subsubsection{Vključevanje končnih uporabnikov}

Vključevanje oseb $\mathrm{z}$ različnimi oblikami oviranosti, ki sicer niso strokovnjaki za ocenjevanje, lahko zelo pomaga pri prepoznavanju ovir, ki jih strokovnjaki sicer ne bi enostavno našli. Čeprav to ni zahteva, je vsekakor smiselno, da se v proces ocenjevanja vključi čim več različnih oseb z različnimi oblikami oviranosti. Pri tem je pomembno, da vodja ocenjevanja $z$ enakimi formularji in enakim postopkom smiselno in ustrezno porazdeli naloge mednje. Rezultate pa na koncu združi v skupno poročilo z ostalimi strokovnjaki, ki sodelujejo pri ocenjevanju. 


\subsubsection{Hevristično ocenjevanje}

Eno od prvih mogočih pravil za uporabnost programskih vmesnikov, ki so določala komunikacijo med človekom in računalnikom, je zapisal Jakob Nielsen [Nielsen, 1990]. Navedel je 10 hevrističnih pravil za načrtovanje uporabniških vmesnikov, ki se še danes zelo pogosto uporabljajo za preverjanje in zagotavljanje uporabnih aplikacij ter spletnih strani. Ta seznam vsebuje vidike, kot so vidnost, vodenje, zaznavanje, učinkovitost, odprava napak in ostale hevristike. Pri tej metodi je dovolj, da uporabimo od 5 do 8 strokovnjakov, ki lahko najdejo do $85 \%$ napak v uporabniškem vmesniku.

Tabela 6 predstavlja primer predloge za poročilo pri hevrističnem ocenjevanju, ki vključuje identifikacijo problema, določitev stopnje problema (primer dobre rešitve, manjši problem, zahtevnejši problem in kritični problem), predlog za rešitve problema in njegovo sliko.

Tabela 6: Primer predloge za hevristično poročilo o uporabnosti

\begin{tabular}{|l|l|}
\hline & $<$ Naslov hevristike - ena od desetih> \\
\hline Stopnja problema & $\begin{array}{l}\text { <Primer dobre rešitve/Manjši problem/Zahtevnejši } \\
\text { problem/Kritični problem }>\end{array}$ \\
\hline Identifikacija problema & $<$ Pojasnilo o identifikaciji problema $>$ \\
\hline Predlog rešitve problema & $<$ Besedilo predloga rešitve problema $>$ \\
\hline Slika & $\begin{array}{l}\text { <Posnetek zaslona } \mathrm{z} \text { grafično označenimi problematičnimi deli } \\
\text { uporabniškega vmesnika }>\end{array}$ \\
\hline
\end{tabular}

$\mathrm{V}$ našem primeru bomo namesto naslova hevristike uporabili naslov enega od $50 \mathrm{kriterijev}$ WCAG o uspešnosti za srednjo raven AA.

\subsubsection{Vprašalniki za ocenjevanje dostopnosti}

Vsak strokovnjak, ocenjevalec pri svojem delu potrebuje oporne točke, na katere se lahko naslanja, ko išče posamezne probleme za določen kriterij uspešnosti. Ena od možnosti je, da se uporabijo navodila in preverjalni seznam v prilogi [Priloga 2]. Druga možnost pa je, da se uporabijo vprašalniki, razviti na Inštitutu za medijske komunikacije Fakultete za elektrotehniko, računalništvo in informatiko Univerze $\mathrm{v}$ Mariboru. S temi vprašalniki, katerega primer $\mathrm{v}$ angleškem jeziku je prikazan na (Sliki 27), lahko hitro in enostavno dobimo prvi vtis o dostopnosti spletnih strani, aplikacije ali produkta, ne da bi potrebovali dodatna zahtevna pravila in določila, ki jih sicer najdemo v smernicah WCAG. Vprašalniki so nastali na osnovi študija drugih vprašalnikov, kot so vprašalniki Luke McGratha 
[McGrath, 2014], ki so prosto dostopni na njegovih spletnih straneh, in na podlagi vprašalnikov na spletnih straneh Web AIM [WebAIM, 2014].

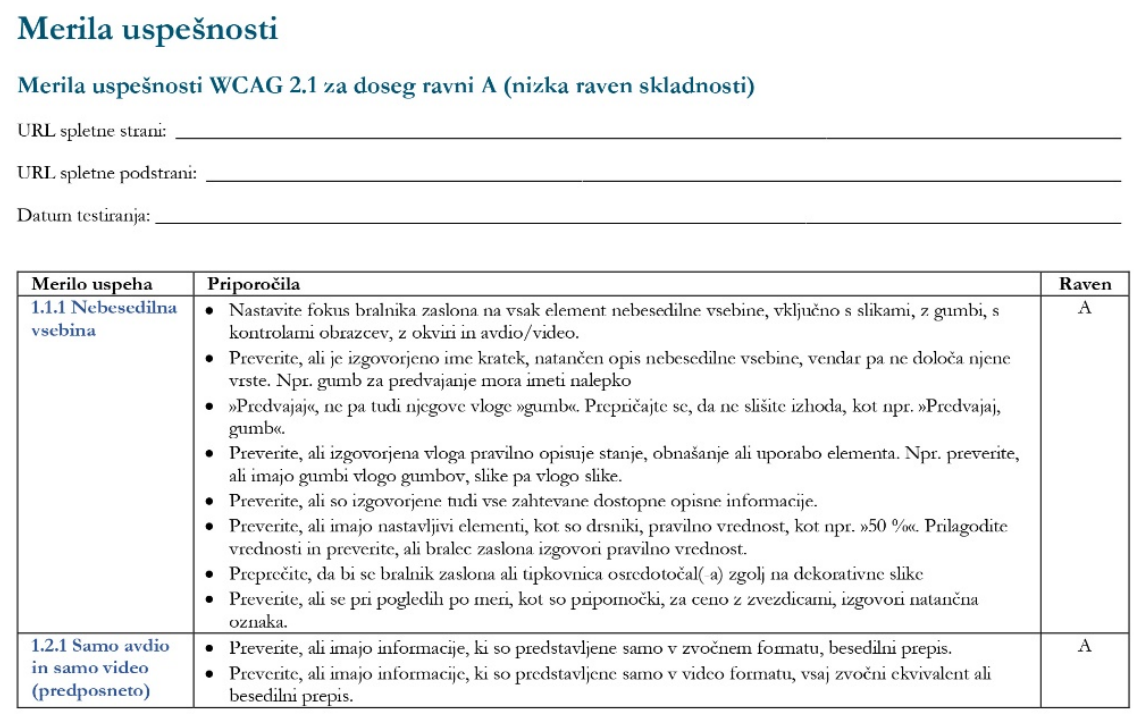

Slika 27: Primer strukture vprašalnika za vprašanja ravni A smernic WCAG (v angleščini)

Za raven AA je na voljo $\mathbf{5 0}$ vprašanj. Slika 27 kaže primer vprašanja za kriterij 1.1.1 Nebesedilna vsebina. Dodana je kolona s predlogi, ki razširijo vsebino kriterija in omogočijo ocenjevalcem, da lažje določijo najbolj problematične točke na spletni strani, pri aplikaciji ali produktu. Dodana je še neposredna povezava na spletne smernice WCAG, kjer lahko ocenjevalec dodatno najde posamezne točke ocenjevanja in primere.

$\mathrm{Na}$ ta način lahko sodeluje tudi manj izkušen strokovnjak, saj ima na voljo različna vprašanja, po katerih se ravna in lažje najde posamezne problematične točke.

\subsection{Postopek ocenjevanja $\mathrm{z}$ uporabo hevrističnega ocenjevanja}

To poglavje predstavlja postopek ocenjevanja z uporabo hevrističnega ocenjevanja. Natančno zaporedje sicer ni potrebno, vendar je odvisno od vodje ocenjevanja, kako bo porazdelil naloge in kakšen bo postopek. Ta je ves odvisen od vrste spletnih strani, mobilne aplikacije in drugega digitalnega pripomočka. Pri spletnih straneh je morda včasih bolje, če ocenjevalce prosimo, da najprej malo brskajo po spletnih straneh, nato pa se seznanijo z ocenjevalnimi kriteriji, ki so jim dodeljeni. Pri mobilni aplikaciji ali digitalnem pripomočku pa lahko najprej določimo kriterije, ki jih ocenjevalci potem preverjajo pri produktu. 
Diagram na Sliki 28 kaže primer postopka izvedbe z uporabo hevrističnega ocenjevanja.

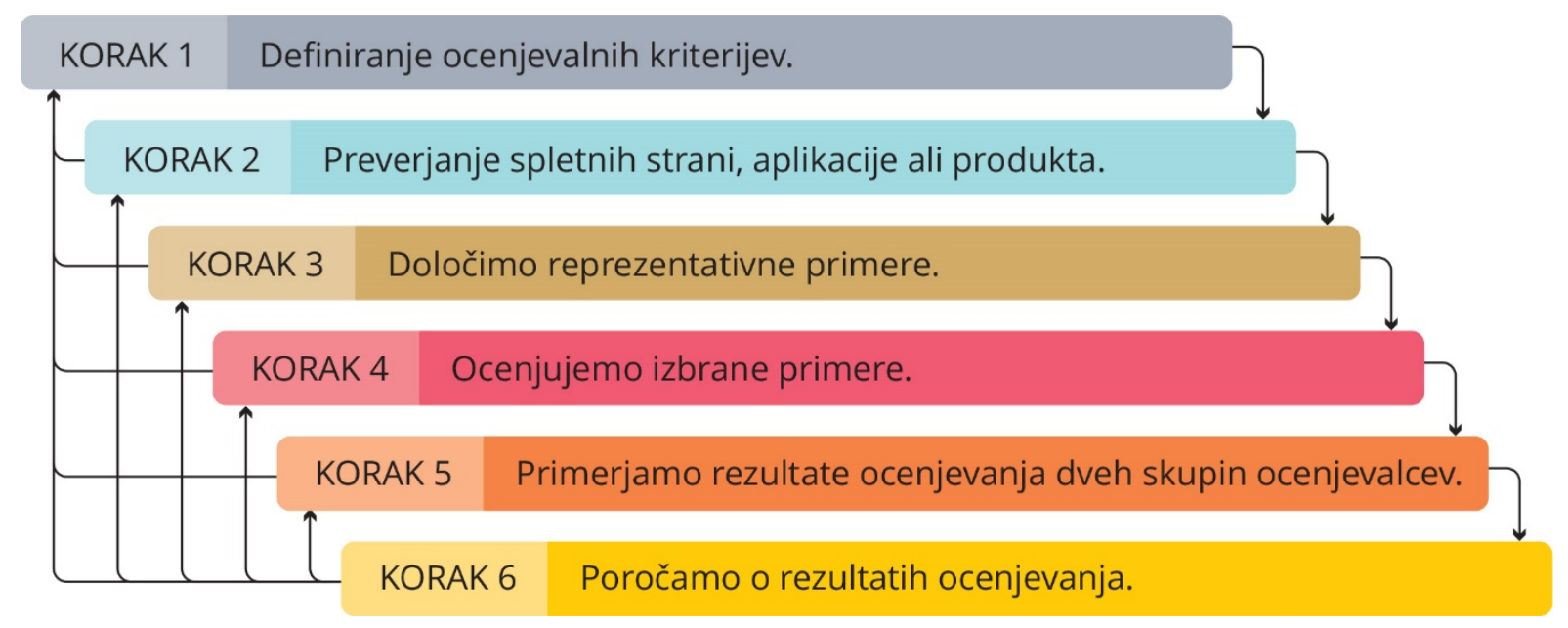

Slika 28: Postopek izvedbe ocenjevanja z uporabo hevrističnega ocenjevanja

$\mathrm{Na}$ začetku določimo vodjo ocenjevanja in število sodelujočih strokovnjakov. Pri hevristični metodi naj bi bilo dovolj, če imamo od tri do osem oseb za ocenjevanje uporabniških vmesnikov. $\mathrm{V}$ tem primeru smo predlagali, da imamo skupino 20 strokovnjakov, ki jih razdelimo na dve skupini. Vsaka nato porazdeli vseh 50 kriterijev uspešnosti tako, da vsak strokovnjak presoja največ pet kriterijev uspešnosti, s čimer zmanjšamo količino dela in povečamo moč koncentracije za vsak posamezni kriterij uspešnosti. Seveda bi bilo priporočljivo uporabiti še več strokovnjakov, če je to mogoče.

Vsi strokovnjaki nato hkrati anonimno izvedejo ocenjevanje. Vodja glede na obsežnost določi časovne okvire za ocenjevanje. Če se ocenjuje manjše število spletnih strani (okrog pet), se lahko ocenjevanje izvede celo v enem dnevu.

Vsaka skupina zase in vsak strokovnjak zase izvedetaocenjevanje brez komuniciranja z ostalimi ocenjevalci. 


\subsection{Poročanje}

Vsak uporabnik dobi predlogo poročila za vsak podani kriterij, kot je prikazano v Tabeli 7 , in ga poskusi izpolniti. Seveda lahko pri vsakem kriteriju najde in opredeli več problemov, in ne samo enega, ter jim določi stopnjo 'problema'.

Tabela 7: Primer predloge za poročanje o problemu za posamezni kriterij uspešnosti

\begin{tabular}{|l|l|}
\hline Kriterij & $<$ Primer: 1.1.1 Nebesedilno besedilo $>$ \\
\hline Stopnja vpliva na dostopnost & $<$ visoka / srednja / nizka $>$ \\
\hline Težavnost odprave & $<$ manjša / srednja / velika $>$ \\
\hline Razlog & $<$ opis problema $>$ \\
\hline Posnetek zaslona & $\begin{array}{l}\text { <posnetek zaslona z grafično poudarjenimi } \\
\text { problematičnimi deli - opcija }>\end{array}$ \\
\hline Programska koda & $<$ opcija $>$ \\
\hline Predlog za rešitev problema & $<$ opis predloga za rešitev problema $>$ \\
\hline Kdo je tipično primeren za odpravo & $<$ programer / urednik strani / oba $>$ \\
\hline
\end{tabular}

Ko se ocenjevanje konča, vodja ocenjevanja preveri skladnost odgovorov vsake skupine s posameznimi kriteriji. Če je pri katerem od kriterijev prišlo do razhajanja, na primer, prva skupina je odgovorila, da je bil kriterij 1.1.1 uspešno rešen, medtem ko je druga ugotovila, da ni bil, vodja usmerja diskusijo in poskuša $\mathrm{v}$ skupinski diskusiji ugotoviti, katera skupina je pravilno določila kriterij uspešnosti.

Vodja nato z vsemi ostalimi pripravi končno poročilo v obliki, kot je to prikazano v prilogi [Priloga 4]. To mora zajemati vsaj naslednje točke:

1. Povzetek

2. Ozadje ocenjevanja

3. Obseg ocenjevanja

4. Ocenjevalci

5. Postopek ocenjevanja

6. Rezultati in predlogi za reševanje

7. Reference

8. Priloge

To poročilo je nato osnova za javno ustanovo, da začne prenovo ali ustrezno nadgradnjo svojega spletišča, mobilne aplikacije ali produkta. 


\subsection{Priprava izjave o dostopnosti}

Glede na Izvedbeni sklep komisije (EU) 2018/1523 z dne 11. oktobra 2018 o določitvi vzorca izjave o dostopnosti v skladu z Direktivo (EU) 2016/2102 Evropskega parlamenta ter Sveta o dostopnosti spletišč in mobilnih aplikacij organov javnega sektorja [EU_A, 2018] in slovenskega Pravilnika o določitvi vzorca izjave o dostopnosti glede skladnosti spletišč in mobilnih aplikacij z zahtevami glede dostopnosti in o metodologiji spremljanja skladnosti spletišč in mobilnih aplikacij [RS_A, 2019] je treba objaviti izjavo o dostopnosti.

Izjava o dostopnosti mora biti enostavno in takoj dosegljiva na spletišču, pri mobilni aplikaciji ali produktu in zajema naslednjo vsebino [EU_A, 2018]:

1. Naziv organa

2. Stopnja skladnosti

3. Nedostopna vsebina

4. Metoda (poglobljena in poenostavljena) ter datum testiranja

5. Povratne in kontaktne informacije

6. Izvršilni postopek

7. <neobvezno> Pojasnilo o zavezanosti k digitalni dostopnosti, povezave na poročilo o oceni, dodatna pomoč za osebe $z$ različnimi oblikami oviranosti

V prilogi [Priloga 5] je predstavljen dejanski primer Izjave o dostopnosti za spletno mesto Univerzitetne knjižnice Maribor.

\subsection{Metoda poglobljenega in poenostavljenega spremljanja}

Glede na Izvedbeni sklep komisije (EU) 2018/1524 z dne 11. oktobra 2018 o določitvi metodologije spremljanja in ureditev poročanja držav članic v skladu z Direktivo (EU) 2016/2102 Evropskega parlamenta ter Sveta o dostopnosti spletišč in mobilnih aplikacij organov javnega sektorja [EU_B, 2018] mora slovenski državni organ uporabiti metodo poglobljenega spremljanja dostopnosti javnih spletišč oziroma mobilnih aplikacij glede na zakone in poročati EU o rezultatih.

Z metodo poglobljenega spremljanja se ocenijo najmanj:

- interakcija z obrazci,

- kontrolniki vmesnika in pogovorna okna, 
- potrditve vnosa podatkov,

- sporočila o napaki in druge povratne informacije, ki nastanejo z uporabniško interakcijo, ter

- obnašanje spletišča ali mobilne aplikacije pri spreminjanju nastavitev ali izbir.

Ta metoda lahko po potrebi vključuje tudi preizkuse uporabnosti, kot sta:

- opazovanje in analiziranje, kako osebe z različnimi oblikami oviranosti zaznavajo vsebino spletišča ali mobilne aplikacije in

- kako zapletena je zanje uporaba sestavnih delov vmesnika, kot so navigacijski meniji ali obrazci.

Metoda poenostavljenega spremljanja pa vključuje ocenjevanje glede na smernice WCAG (zaznavnost, upravljivost, razumljivost in robustnost) ob uporabi vsaj avtomatiziranih orodij, in to za čim večji nabor uporabnikov.

Države članice lahko pri poenostavljenem spremljanju poleg avtomatiziranih preizkusov uporabljajo tudi druge, na primer ročne.

Po končanem spremljanju oziroma preizkusu državni organi pripravijo poročilo za EU, ki mora zajemati vsaj naslednje točke, podane tudi v zakonu [EU_B, 2018].

1. Povzetek poročila;

2. Opis dejavnosti spremljanja (splošno, vzorec, skladnost s standardi);

3. Izid spremljanja (podroben izid za poglobljeno in poenostavljeno metodo ter dodatno vsebino);

4. Uporaba izvršilnega postopka in povratne informacije končnega uporabnika;

5. Vsebina, povezana $z$ dodatnimi ukrepi;

6. Reference;

7. Priloge. 


\section{$8 \quad$ Zaključek}

V monografiji smo opisali problematiko analize, oblikovanja in ocenjevanja dostopnosti digitalnih produktov $z$ več različnih vidikov: zajeli smo predstavitev zahtev in potreb oseb z različnimi oblikami oviranosti, pravila in standarde, ki veljajo za področje dostopnosti, splošna pravila za vizualno oblikovanje ter pravila in postopke ocenjevanja dostopnosti glede na zakon o dostopnosti.

Zavedati se moramo, da dostopnost produktov postaja pomemben dejavnik ne samo v javnih institucijah, organih, temveč tudi v poslovnem okolju. To okolje bo namreč tisto, ki bo imelo neposreden vpliv na to, kako bodo digitalni produkti dostopni za vse. Gre torej za globalno urejanje in izvajanje novih postopkov oblikovanja, med drugim predvsem oblikovanja uporabniških vmesnikov.

Ugotovili smo, da za ureditev dostopnosti ni dovolj, da samo uredimo slike tako, da jim dodamo še neko besedilo, ki jih opisuje, temveč je treba urediti še mnogo drugih elementov $\mathrm{v}$ komunikaciji med digitalnim produktom in osebami z različnimi oblikami oviranosti. Vsi ti so zajeti v vseh 50-ih merilih uspešnosti za srednjo raven skladnosti AA, kot jih določajo zakoni in standardi. 
Dostopnost pa ni samo domena programerjev in grafičnih oblikovalcev, temveč tudi urednikov, urejevalcev in vnašalcev informacij. Prav tako morajo biti s pravili za dostopnost ter s potrebami in $z$ zahtevami seznanjeni tudi odločevalci in vodstva organizacij. Vsi ti namreč predstavljajo pomembne kamenčke na končni poti do ustrezne dostopnosti digitalnih produktov.

Kako se torej lotiti ocenjevanja? Ugotovili smo, da lahko začne ocenjevanje čisto vsak s postavljanjem enostavnih vprašanj, ki smo jih $\mathrm{v}$ monografiji poimenovali »Hitro preverjanje«. Ta del je primeren za vse, tudi za tiste, ki skoraj nič ne vedo o dostopnosti, vendar bi radi ugotovili, kakšna je dostopnost njihovega produkta. $\mathrm{V}$ tem delu odgovarjamo samo na 12 točk, in sicer preverjamo vsaj naslov, alternativno besedilo za slike, besedilo, interakcijo in splošne vidike, kot sta premikanje in utripanje, multimedijske (video in avdio) alternative ter osnovno strukturo, zgradbo produktov.

Naslednji korak je uporaba diagnostičnih programskih orodij, s katerimi preverjamo spletno stran ali tudi spletišča glede na zakonsko določena merila uspešnosti. Ta del je že bolj namenjen urednikom, oblikovalcem, programerjem in strokovnjakom za dostopnost. Nekatera orodja so enostavnejša in dajejo predvsem splošno mnenje, druga pa zahtevnejša in zahtevajo dobro znanje programiranja. Katero orodje izbrati, je odvisno predvsem od samega uporabnika in njegovih potreb.

Sledi korak, ki ga izvedejo predvsem strokovnjaki za dostopnost. Ti raziščejo vsa merila dostopnosti in se pri tem poglobijo predvsem $\mathrm{v}$ tista, ki zahtevajo ročno preverjanje. Nekatera merila so namreč takšne narave, da jih ne moremo preveriti s samodejnimi orodji, temveč jih je treba preizkusiti ročno. Katera so ta merila, smo tudi v monografiji posebej izpostavili.

Kot zaključni korak sledi priprava zakonsko določene izjave o dostopnosti, ki jo morata po zakonu imeti vsako spletišče in mobilna aplikacija.

Čeprav smo morda s tem zadostili zakonskim zahtevam, pa še vedno ostaja odprto vprašanja, ali so digitalni produkti resnično dovolj dostopni za vse. Treba je še naprej ozaveščati o potrebah in možnostih oseb z različnimi oblikami oviranosti ter o oblikah in primerih dobre prakse za dostopne digitalne produkte. 
Monografija dejansko predstavlja samo kamenček na poti, posebno če jo primerjamo z velikansko količino informacij na spletnih straneh ter $z$ navodili za dostopnost in drugimi knjigami. Pa vendarle lahko tudi ta kamenček predstavlja učinkovit in enostaven pripomoček pri prepoznavanju dostopnosti digitalnih produktov. In če ni, ga ne kupimo ali ne uporabimo. In to velja za vse. 


\section{Literatura}

A11yportal (2020). Visual Design. Vir: https://www.a11yportal.com/guidelines/design/visual-design.html A11Portal_A (2020). Do's and Dont's. Vir: https://www.a11yportal.com/basics/fundamentals/dos-and-donts.html Adam, A., \& Kreps, D. (2006). Web accessibility: a digital divide for disabled people?. In Social inclusion: Societal and organizational implications for information systems (pp. 217-228). Springer, Boston, MA.

Aylward, M., Dewis, P., Henderson, M. (1998). The Disability Handbook: A Handbook on the Care Needs and Mobility Requirements Likely to Arise from V arious Disabilities and Chronic Illnesses. The Stationery Office Books (Agencies); $2 n d$ Edition

Burgstahler, S. (2009). Universal Design: Process, Principles, and Applications. DO-IT.

Carey, J., Elton M. C. J. (2010). When Media Are New: Understanding the Dynamics of New Media Adoption and Use, New Media World Damron-Rodriguez, J., Wallace, S., \& Kington, R. (1995). Service utilization and minority elderly: Appropriateness, accessibility and acceptability. Gerontology \& Geriatrics Education, 15(1), $45-64$.

Davis, L. J. (2017). The Disability Studies Reader. Taylor \& Francis.

Debevc, M., Kožuh, I., Hauptman, S., Klembas, A., Lapuh Bele, J., Holzinger, A. (2015). Using WCAG 2.0 and heuristic evaluation to evaluate accessibility in educational web based pages, LTEC

Demšar, D., Krajnc, A., Vesel, A., Pochyla, D., Klemenčič, A., Smerdel, A., Lištvanova, L. (2015). Dostopnost spletnih strani. Beletrina.

Dimic Kesič, K., Blažič, M., Kavkler, M. (2010). Vsi učenci so lahko uspešni: napotki za delo z učenci s posebnimi potrebami : preizkušeni nasveti in zamisli za učinkovito poučevanje. Rokus Klett.

European Telecommunications Standards Institute - ETSI (2018). Standard SIST EN 301549 V2.1.2:2018, Zahteve za dostopnost izdelkov in storitev IKT.

Ernecl, T. (2018). Sodelovanje med starši, specialnim pedagogom in vagojïtelji v vrtcu (Doktorska dizertacija, Univerza v Mariboru, Pedagoška fakulteta).

European Union - EU (2002). Direktiva 2002/22/ES Evropskega parlamenta in Sveta z dne 7. marca 2002 o univerzalni storitvi in pravicah uporabnikov $\mathrm{v}$ zvezi z elektronskimi komunikacijskimi omrežji in storitvami (Direktiva o univerzalnih storitvah). Vir: https://eur-lex.europa.eu/legalcontent/sl/TXT/?uri=CELEX\%3A32002L0022

European Union - EU (2016). Direktiva (EU) 2016/2102 Evropskega parlamenta in Sveta z dne 26. oktobra 2016 o dostopnosti spletišč in mobilnih aplikacij organov javnega sektorja. Vir: https://eur-lex.europa.eu/legalcontent/SL/TXT/?uri=celex:32016L2102

European Union - EU (2018). Direktiva o avdiovizualnih medijskih storitvah (direktiva o AVMS). Vir: https:/ / eurlex.europa.eu/legal-content/SL/TXT/?uri=LEGISSUM\%3Aam0005

European Union - EU (2019). Direktiva (EU) 2019/882 Evropskega parlamenta in Sveta z dne 17. aprila 2019 o zahtevah glede dostopnosti za proizvode in storitve. Vir: https://eur-lex.europa.eu/legalcontent/sl/TXT/?uri=CELEX\%3A32019L0882 
European Union - EU_A (2018). Izvedbeni sklep komisije (EU) 2018/1523 z dne 11. oktobra 2018 o določitvi vzorca izjave o dostopnosti v skladu z Direktivo (EU) 2016/2102 Evropskega parlamenta in Sveta o dostopnosti spletišč in mobilnih aplikacij organov javnega sektorja

European Union - EU_B (2018). Izvedbeni sklep komisije (EU) 2018/1524 z dne 11. oktobra 2018 o določitvi metodologije spremljanja in ureditev poročanja držav članic v skladu z Direktivo (EU) 2016/2102 Evropskega parlamenta in Sveta o dostopnosti spletišč in mobilnih aplikacij organov javnega sektorja

Eurostat (2015). Disability statistics. Vir: https://ec.europa.eu/eurostat/statisticsexplained/index.php/Disability_statistics

Eurostat (2017). 1 in 4 people in the EU have a long-term disability. Vir: https://ec.europa.eu/eurostat/web/productseurostat-news/-/EDN-20181203-1?inheritRedirect=true

Ferk, M. (2017). Učinkovitost predlog e-gradiva za osebe s posebnimi potrebami. Univerza v Mariboru, magistrsko delo. Vir: https://dk.um.si/Dokument.php?id=119919\&lang=slv

Freedom Scientific (2020). JAWS https://www.freedomscientific.com/products/software/jaws/

Frey, J., Veler, A., Kermauner, A. (2005). Velike zelene oči. Ljubljana: Mladinska knjiga

Gillen, G. (2009). Cognitive and perceptual rehabilitation. Optimiring function. Missouri: Mosby Elsevier.

Griffith L, Raina P, Wu H, et al. (2010). Population attributable risk. for functional disability associated with chronic conditions in Canadian older adults. Age Ageing. Nov 39(6):738-45.

Hersh, M., \& Johnson, M. A. (Eds.). (2010). Assistive technology for visually impaired and blind people. Springer Science $\&$ Business Media.

Holzinger, A. (2005). Usability engineering methods for software developers. Communications of the ACM, 48(1), 71-74.

Horvat, B. (2013). Nekateri aspekti gibalno ovirane invalidnosti. Anthropos: Časopis za psihologijo in filozofijo ter za sodelovanje humanističnih ved, 45.

Inclusive City Maker (2019). Disabled People in the World in 2019: facts and figures. Vir: https://www.inclusivecitymaker.com/disabled-people-in-the-world-in-2019-facts-and-figures/

Jamnik, T. (2016). Tesnoba pri starših otrok z dodatno strokouno pomočjo (Doktorska dizertacija, Univerza v Ljubljani, Pedagoška fakulteta)

Kalbag, L. (2017). Accessibility for Everyone. A Book Apart, New York.

Kesič Dimic, K., Blažič, M., Kavkler, M. (2010). Vsi učenci so lahko uspešni: napotki za delo z učenci s posebnimi potrebami. Ljubljana: Rokus Klett.

Kobolt, A., Rajniš Pinterič, M., Rogelj, F., Čuzić, L., Rogelj, S., \& Andrenšek Lep, B. (2015). Otroci s čustvenimi in vedenjskimi motnjami (Doktorska dizertacija, Univerza v Ljubljani, Pedagoška fakulteta)

Kulkarni, M. (2019). Digital accessibility: Challenges and opportunities. IIMB Management Review, 31(1), 91-98.

Lazar, J., Goldstein, D. F., \& Taylor, A. (2015). Ensuring digital accessibility through process and policy. Morgan Kaufmann.

Martínez Usero, J. A., Beltrán Orenes, P., Martínez Comeche, J. A., \& San Segundo Manuel, R. (2006). Information interoperability evaluation model for public web sites. In Current research in Information Sciences and Technologies (str. 453-457). Open Institute of Knowledge.

McGrath, L. (2014). What are the Web Content Accessibility Guidelines 2.0? Vir: http:/ /www.wuhcag.com/web-contentaccessibility-guidelines/.

Ministrstvo za delo, družino, socialne zadeve in enake možnosti - MDDSEM (2020). Mreža izvajalcev zaposlitvene $\begin{array}{llllll}\text { rehabilitacije } & \mathrm{za} & \text { obdobje } & 2021 . & \text { Vir: }\end{array}$ https://www.gov.si/assets/ministrstva/MDDSZ/Invalidi/Zaposlitvena-rehabilitacija-2021-

2027/Mreza_izvajalcev_ZR_2021_2027.pdf

Murn, T. (2020). Opredelitev skupine slepih in slabovidnih otrok. Vir: https://www.otroci-s-posebnimipotrebami.si/vsebine/slepi-slabovidni-otroci/strokovne-zakonske-razlage/opredelitev-inzna\%C4\%8Dilnosti/opredelitev-skupine-slepih-in-slabovidnih-otrok/\#fn1

Nielsen J. (1994). Usability inspection methods. In: Conference companion on Human factors in computing systems, ACM, 413414.

Nielsen, J., \& Molich, R. (1990, March). Heuristic evaluation of user interfaces. In Proceedings of the SIGCHI conference on Human factors in computing systems (pp. 249-256).

Pernice, K., Nielsen, J. (2001). Usability Guidelines for Accessible Web Design. Nielsen Norman Group

Puc, N. (2017). Pomen spremljevalca pri vključevanju otroka z gibalno oviranostjo-Spina bifida v vrtec (Doktorska dizertacija, Univerza na Primorskem, Pedagoška fakulteta).

Richens, E.P., Knight, J. (2015). How to design design for accessibility. BBC. Vir: https://www.bbc.co.uk/gel/guidelines/how-to-design-for-accessibility

Riley-Huff, D. A. (2012). Web accessibility and universal design. Library Technology Reports, 48(7), 29-35. 
Republika Slovenija - RS (1991). Ustava Republike Slovenije. Vir: http://pisrs.si/Pis.web/pregledPredpisa?id=USTA1

Republika Slovenija - RS (2002). Zakon o uporabi slovenskega znakovnega jezika (ZUSZJ). Vir: http://www.pisrs.si/Pis.web/pregledPredpisa?id=ZAKO1713

Republika Slovenija - RS (2004). Zakon o zaposlitveni rehabilitaciji in zaposlovanju invalidov (ZZRZI). Vir: http://pisrs.si/Pis.web/pregledPredpisa?id=ZAKO3841

Republika Slovenija - RS (2010). Zakon o izenačevanju možnosti invalidov (ZIMI). Vir: http://www.pisrs.si/Pis.web/pregledPredpisa?id=ZAKO4342

Republika Slovenija - RS (2011). Zakon o usmerjanju otrok s posebnimi potrebami (ZUOPP-1). Vir: http://pisrs.si/Pis.web/pregledPredpisa?id=ZAKO5896

Republika Slovenija - RS (2018). Zakon o dostopnosti spletišč in mobilnih aplikacij (ZDSMA). Vir: http://www.pisrs.si/Pis.web/pregledPredpisa?id=ZAKO7718

Republika Slovenija - RS-A (2019). Pravilnik o določitvi vzorca izjave o dostopnosti glede skladnosti spletišč in mobilnih aplikacij z zahtevami glede dostopnosti in o metodologiji spremljanja skladnosti spletišč in mobilnih aplikacij.

San Giorgi, A. S. (2019). Inclusive Design Toolkit: Design and Validation of a Search System for a Wide Variety of Users (Master's thesis).

Sethfors, H. (2017). Practical Examples of Accessibility Improvements. Axess Lab. Vir: https://axesslab.com/practicalaccessibility-improvements/

Stokoe, W. C., Sign language structure. An outline of the visual communication systems of the American Deaf. Silver Spring, MD: Linstok Press. 1960.

Tabaj, A. (2014). Izenačevanje možnosti invalidov - dostopnost do blaga in storitev, Univerzitetni rehabilitacijski inštitut Republike Slovenije - Soča. Vir: http://www.irrs.si/f/docs/Razvojni_center_za_zaposlitveno_rehabilitacij/ZIMI_Dostopnost_do_blaga_in_storite.pdf

United Nations Organisation - UNO (2006). Konvencija o pravicah invalidov. Vir: https://www.un.org/disabilities/documents/natl/slovenia.doc

United Nations Organisation - UNO (2020). Agenda za trajnostni razvoj. Vir: https://www.gov.si/assets/vladnesluzbe/SVRK/Agenda-2030/Spremenimo_svet_-_Agenda_za_trajnostni_razvoj_2030_1_-3.doc

Vovk-Ornik, N. (2015). Kriteriji za opredelitev vrste in stopnje primanjkljajev, ovir oz: motenj otrok posebnimi potrebami. Druga izdaja. Ljubljana: Zavod za šolstvo. Vir: http://www.zrss.si/pdf/Kriteriji-motenj-otrok-sposebnimipotrebami.pdf

World Wide web Consortium - W3C (2018). Web Content Accessibility Guidelines (WCAG) 2.1. Vir: https://www.w3.org/TR/WCAG21/

World Wide web Consortium - W3C (2020). Accessibility Basics. Vir: https://www.w3.org/wiki/Accessibility_basics

World Wide web Consortium - W3C_A (2020). Evaluating Web Accessibility Overview. Vir: https://www.w3.org/WAI/test-evaluate/

World Wide web Consortium - W3C_B (2020). Easy Checks - A First Review of Web Accessibility. Vir: https://www.w3.org/WAI/test-evaluate/preliminary/

WEBAIM (2014). WEBAIM Checklist, WebAIM (Web Accessibility in Mind, http://webaim.org/standards/wcag/checklist

WebAIM (2020). The WebAIM Million, 2020. Vir: https://webaim.org/projects/million/

World Health Organization - WHO (2011). World Report on Disability, WHO Library. Vir: https://www.who.int/disabilities/world_report/2011/report/en/

World Health Organization - WHO (2020). Grades of hearing impairment. Vir: https://www.who.int/pbd/deafness/hearing_impairment_grades/en/

World Health Organization - WHO (2001). International Classification of Functioning, Disability and Health (ICF). Vir: https://www.who.int/classifications/icf/en/

Wilson, B. S., Finley, C. C., Lawson, D. T., Wolford, R. D., Eddington, D. K., \& Rabinowitz, W. M. (1991). Better speech recognition with cocblear implants. Nature, 352(6332), 236-238.

Wong, B. (2011). Color blindness. nature methods, 8(6), 441-442.

World Bank (2020), Disability Inclusion. Vir: https://www.worldbank.org/en/topic/disability

Žagar, D. (2012). Drugačni učenci. Prva izdaja. Ljubljana: Znanstvena založba Filozofske fakultete. 
Merila uspešnosti WCAG 2.1 za doseg ravni AA - seznam za preverjanje

\begin{tabular}{|c|c|c|}
\hline $\begin{array}{l}\text { WCA 2.1 } \\
\text { navodila s } \\
\text { povezavami do } \\
\text { spletišč W3C }\end{array}$ & Merilo uspeha & Raven \\
\hline \multicolumn{3}{|l|}{ ZAZNAVNOST } \\
\hline \multicolumn{3}{|c|}{ Besedilna nadomestila } \\
\hline 1.1 .1 & Nebesedilna vsebina & A \\
\hline \multicolumn{3}{|l|}{ Časovni mediji } \\
\hline 1.2 .1 & Samo avdio in samo video (predposneto) & A \\
\hline 1.2 .2 & Podnapisi (predposneti) & A \\
\hline 1.2 .3 & Zvočni zapis ali nadomestilo za medij (predposneto) & A \\
\hline 1.2.4 & Podnapisi (v živo) & AA \\
\hline 1.2 .5 & Zvočni opis (predposnet) & $\mathrm{AA}$ \\
\hline \multicolumn{3}{|l|}{ Prilagodljivost } \\
\hline 1.3 .1 & Informacije in povezave & A \\
\hline 1.3 .2 & Smiselno zaporedje & A \\
\hline 1.3 .3 & Čutne značilnosti & A \\
\hline 1.3 .4 & Usmeritev & $\mathrm{AA}$ \\
\hline 1.3 .1 & Prepoznava namena vnosa & AA \\
\hline \multicolumn{3}{|l|}{ Razločljivost } \\
\hline 1.4 .1 & Uporaba barve & A \\
\hline 1.4 .2 & Nadzor zvoka & A \\
\hline 1.4 .3 & Kontrast (najmanjši) & $\mathrm{AA}$ \\
\hline 1.4 .4 & Spreminjanje velikosti besedila & AA \\
\hline 1.4 .5 & Slike besedila & $\mathrm{AA}$ \\
\hline 1.4 .10 & Prerazporeditev & $\mathrm{AA}^{*}$ \\
\hline 1.4 .11 & Nebesedilni kontrast & $\mathrm{AA}^{*}$ \\
\hline 1.4 .12 & Medbesedilni razmik & $\mathrm{AA}^{*}$ \\
\hline 1.4 .13 & Vsebina na lebdenju ali fokusu & $\mathrm{AA}^{*}$ \\
\hline
\end{tabular}

\begin{tabular}{|c|c|c|}
\hline \multicolumn{3}{|c|}{ UPRAVLJIVOST } \\
\hline \multicolumn{3}{|c|}{ Tipkovnična dostopnost } \\
\hline 2.1 .1 & Tipkovnica & A \\
\hline 2.1 .2 & Brez tipkovničnega zastoja & A \\
\hline 2.1 .4 & Bližnjične tipke & $\mathrm{A}$ \\
\hline \multicolumn{3}{|c|}{ Dovolj časa } \\
\hline 2.2 .1 & Nastavljiva izbira časa & $\mathrm{A}$ \\
\hline 2.2 .2 & Premor, ustavitev, skrivanje & A \\
\hline
\end{tabular}




\begin{tabular}{|c|c|c|}
\hline \multicolumn{3}{|c|}{ Napadi in fizični odzivi } \\
\hline 2.3 .1 & Trije utripi ali pod pragom & A \\
\hline \multicolumn{3}{|l|}{ Krmljivost } \\
\hline 2.4 .1 & Obvod vsebine & $\mathrm{A}$ \\
\hline 2.4 .2 & Stran $\mathrm{z}$ naslovom & A \\
\hline 2.4 .3 & Fokusni red & A \\
\hline 2.4 .4 & Namen povezave (v kontekstu) & A \\
\hline 2.4 .5 & Več načinov & AA \\
\hline 2.4 .6 & Naslovi in oznake & AA \\
\hline 2.4 .7 & Viden fokus & AA \\
\hline \multicolumn{3}{|c|}{ Modaliteta vnosa } \\
\hline 2.5 .1 & Gibi kazalca & A \\
\hline 2.5 .2 & Preklic kazalca & A \\
\hline 2.5 .3 & Oznaka v imenu & A \\
\hline 2.5 .4 & Aktiviranje gibanja & A \\
\hline
\end{tabular}

\section{RAZUMLJIVOST}

\section{Berljivost}

\begin{tabular}{|c|c|c|}
\hline 3.1 .1 & Jezik strani & $\mathrm{A}$ \\
\hline 3.1 .2 & Jezik delov & AA \\
\hline \multicolumn{3}{|c|}{ Predvidljivost } \\
\hline 3.2 .1 & $\mathrm{~V}$ fokusu & A \\
\hline 3.2 .2 & $\mathrm{Na}$ vhodu & $\mathrm{A}$ \\
\hline 3.2 .3 & Dosledna navigacija & $\mathrm{AA}$ \\
\hline 3.2 .4 & Dosledna identifikacija & $\mathrm{AA}$ \\
\hline \multicolumn{3}{|c|}{ Pomoč pri vnosu } \\
\hline 3.2.1 & Identifikacija napake & A \\
\hline 3.2 .2 & Oznake ali navodila & A \\
\hline 3.2 .3 & Nakazovanje napake & $\mathrm{AA}$ \\
\hline 3.2 .4 & Preprečevanje napak (pravnih, finančnih, podatkovnih) & $\mathrm{AA}$ \\
\hline
\end{tabular}

\section{ROBUSTNOST}

Združljivost

\begin{tabular}{|l|l|r|}
\hline 4.1 .1 & Razčlenjevanje & $\mathrm{A}$ \\
\hline 4.1 .2 & Ime, vloga, vrednost & $\mathrm{A}$ \\
\hline 4.1 .3 & Statusna sporočila & $\mathrm{AA}$ \\
\hline
\end{tabular}

Vir: Web Accessibility Assessment Methodology (Level AA) 
WCAG 2.1 preverjalni seznam za posamezno merilo uspešnosti

\begin{tabular}{|c|c|c|c|c|c|}
\hline \multicolumn{5}{|c|}{ WCAG 2.1 AA Preverjalni seznam } & \multirow[b]{2}{*}{$\begin{array}{l}\text { Orodje/ } \\
\text { ročno }\end{array}$} \\
\hline $\begin{array}{l}\text { Merilo } \\
\text { uspešnosti }\end{array}$ & \# & Raven & Navodilo & Testna vprašanja in določila & \\
\hline $\begin{array}{l}\text { Nebesedilna } \\
\text { vsebina }\end{array}$ & 1.1.1 & A & $\begin{array}{l}\text { Besedilna } \\
\text { nadomestila }\end{array}$ & $\begin{array}{l}\text { Nastavite fokus bralnika zaslona na vsak } \\
\text { element nebesedilne vsebine, vključno s } \\
\text { slikami, z gumbi, s kontrolami obrazcev, z } \\
\text { okviri in avdio/video. } \\
\text { Preverite, ali je izgovorjeno ime kratek, } \\
\text { natančen opis nebesedilne vsebine, vendar } \\
\text { pa ne določa njene vrste. Npr. gumb za } \\
\text { predvajanje mora imeti nalepko } \\
\text { „Predvajaj«, ne pa tudi njegove vloge } \\
\text { »gumb«. Prepričajte se, da ne slišite izhoda, } \\
\text { kot npr. »Predvajaj, gumb«. } \\
\text { Preverite, ali izgovorjena vloga pravilno } \\
\text { opisuje stanje, obnašanje ali uporabo } \\
\text { elementa. Npr. preverite, ali imajo gumbi } \\
\text { vlogo gumbov, slike pa vlogo slike. } \\
\text { Preverite, ali so izgovorjene tudi vse } \\
\text { zahtevane dostopne opisne informacije. } \\
\text { Preverite, ali imajo nastavljivi elementi, kot } \\
\text { so drsniki, pravilno vrednost, kot npr. »50 } \\
\text { \%«. Prilagodite vrednosti in preverite, ali } \\
\text { bralec zaslona izgovori pravilno vrednost. } \\
\text { Preprečite, da bi se bralnik zaslona ali } \\
\text { tipkovnica osredotočal(-a) zgolj na } \\
\text { dekorativne slike } \\
\text { Preverite, ali se pri pogledih po meri, kot } \\
\text { so pripomočki, za oceno z zvezdicami, } \\
\text { izgovori natančna oznaka. }\end{array}$ & $\begin{array}{l}\text { aXe } \\
\text { WAVE } \\
\text { aChecker } \\
\ldots\end{array}$ \\
\hline $\begin{array}{l}\text { Samo avdio in } \\
\text { samo video } \\
\text { (predposneto) }\end{array}$ & 1.2 .1 & A & $\begin{array}{l}\text { Časovni } \\
\text { mediji }\end{array}$ & $\begin{array}{l}\text { Preverite, ali imajo informacije, ki so } \\
\text { predstavljene samo v zvočnem formatu, } \\
\text { besedilni prepis. } \\
\text { Preverite, ali imajo informacije, ki so } \\
\text { predstavljene samo v video formatu, vsaj } \\
\text { zvočni ekvivalent ali besedilni prepis. }\end{array}$ & Ročno \\
\hline $\begin{array}{l}\text { Podnapisi } \\
\text { (predposneti) }\end{array}$ & 1.2 .2 & A & $\begin{array}{l}\text { Časovni } \\
\text { mediji }\end{array}$ & $\begin{array}{l}\text { V nastavitvah omogočite zaprte napise. } \\
\text { Predvajajte video posnetke. } \\
\text { Preverite, ali video posnetki vsebujejo } \\
\text { sinhronizirane napise. } \\
\text { Prepričajte se, ali so napisi točni. }\end{array}$ & $\begin{array}{l}\text { aXe } \\
\text { WAVE } \\
\text { aChecker } \\
\ldots\end{array}$ \\
\hline $\begin{array}{l}\text { Zvočni zapis ali } \\
\text { nadomestilo za } \\
\text { medij } \\
\text { (predposneto) }\end{array}$ & 1.2 .3 & A & $\begin{array}{l}\text { Časovni } \\
\text { mediji }\end{array}$ & $\begin{array}{l}\text { Predvajajte video posnetke. } \\
\text { Če je vključen zaprti posnetek zvočnih } \\
\text { opisov, se mora prikazati gumb jezika. } \\
\text { Aktivirajte gumb »Jezik«, izberite posnetek } \\
\text { zvočnih opisov. } \\
\text { Prepričajte se, ali so zvočni opisi točni. }\end{array}$ & Ročno \\
\hline $\begin{array}{l}\text { Podnapisi (v } \\
\text { živo) }\end{array}$ & 1.2 .4 & $\mathrm{AA}$ & $\begin{array}{l}\text { Časovni } \\
\text { mediji }\end{array}$ & $\begin{array}{l}\text { Preverite, da so za avdio/video } \\
\text { predstavitve na voljo napisi v živo. }\end{array}$ & $\begin{array}{l}\text { aXe } \\
\text { WAVE } \\
\text { aChecker } \\
\ldots \\
\end{array}$ \\
\hline
\end{tabular}




\begin{tabular}{|c|c|c|c|c|c|}
\hline $\begin{array}{l}\text { Zvočni opis } \\
\text { (predposnet) }\end{array}$ & 1.2 .5 & $\mathrm{AA}$ & $\begin{array}{l}\text { Časovni } \\
\text { mediji }\end{array}$ & $\begin{array}{l}\text { Predvajajte video posnetke. } \\
\text { Če je vključen zaprti posnetek zvočnih } \\
\text { opisov, se mora prikazati gumb jezika. } \\
\text { Aktivirajte gumb »Jezik«, izberite posnetek } \\
\text { zvočnih opisov. } \\
\text { Prepričajte se, ali so zvočni opisi točni. }\end{array}$ & Ročno \\
\hline $\begin{array}{l}\text { Informacije in } \\
\text { povezave }\end{array}$ & 1.3 .1 & A & Prilagodljiv & $\begin{array}{l}\text { Krmilite po vseh pomenskih elementih } \\
\text { HTML z uporabo kretenj bralnika zaslona } \\
\text { ali ukazov tipkovnice. } \\
\text { Nastavite fokus bralnika zaslona na } \\
\text { naslove, sezname ter tabele in preverite, ali } \\
\text { so pravilno kodirani s pomenskim HTML } \\
\ldots \\
\text { Če ne morete določiti fokusa elementa, za } \\
\text { katerega se zdi, da je naslov, kadar } \\
\text { uporabljate ukaze za hitro navigacijo, } \\
\text { potem ni kodiran s pomenskim HTML. } \\
\text { Z bralnikom zaslona se pomikajte med } \\
\text { vrsticami in stolpci znotraj podatkovne } \\
\text { tabele in preverite, ali so izgovorjeni } \\
\text { pravilni naslovi vrstic in stolpcev. } \\
\text { Preverite, ali je besedilo <legende> } \\
\text { izgovorjeno za vsak < vhod> }>\text { v naboru } \\
\text { polja>, ko bralec zaslona nastavi fokus na } \\
\text { vhod v skupini. } \\
\text { Uporabite navigacijo po mejnikih, da } \\
\text { preverite, ali lahko skačete med vidno } \\
\text { razločnimi naslovi, navigacijo, glavno } \\
\text { vsebino ter regijami s podnožnim } \\
\text { besedilom na strani. }\end{array}$ & $\begin{array}{l}\text { aXe } \\
\text { WAVE } \\
\text { aChecker } \\
\ldots\end{array}$ \\
\hline $\begin{array}{l}\text { Smiselno } \\
\text { zaporedje }\end{array}$ & 1.3 .2 & A & Prilagodljiv & $\begin{array}{l}\text { Pomaknite se skozi vse elemente na } \\
\text { zaslonu od zgoraj navzdol in preverite, ali } \\
\text { se vrstni red branja ujema z vrstnim redom } \\
\text { vizualne predstavitve. } \\
\text { Preverite, ali je vsebina prebrana v vrstnem } \\
\text { redu, ki ne zmoti pomena. }\end{array}$ & $\begin{array}{l}\text { Samo } \\
\text { bralniki } \\
\text { zaslona }\end{array}$ \\
\hline $\begin{array}{l}\text { Čutne } \\
\text { značilnosti }\end{array}$ & 1.3.3 & A & Prilagodljiv & $\begin{array}{l}\text { Preverite, ali se navodila za uporabo } \\
\text { aplikacije ne zanašajo samo na vizualne ali } \\
\text { zvočne informacije. }\end{array}$ & Ročno \\
\hline Usmeritev & 1.3.4 & $\mathrm{AA}$ & Prilagodljiv & $\begin{array}{l}\text { Orientacija spletnih vsebin ni omejena le } \\
\text { na portret ali ležečo pokrajino, razen če je } \\
\text { posebna orientacija potrebna. }\end{array}$ & Ročno \\
\hline $\begin{array}{l}\text { Prepoznava } \\
\text { namena vnosa }\end{array}$ & 1.3.5. & $\mathrm{AA}$ & Prilagodljiv & $\begin{array}{l}\text { Namen vsakega vhodnega polja, ki zbira } \\
\text { podatke o uporabniku, je mogoče } \\
\text { programsko določiti, ko: } \\
\text { - vnosno polje služi namenu, ki je } \\
\text { določen v razdelku; } \\
\text { - } \quad \text { se vsebina izvaja s tehnologijami s } \\
\text { podporo za prepoznavanje } \\
\text { pričakovanega pomena za vhodne } \\
\text { podatke obrazca. }\end{array}$ & Ročno \\
\hline Uporaba barve & 1.4 .1 & A & Razločljiv & $\begin{array}{l}\text { Nastavite napravo tako, da bo uporabljala } \\
\text { sive odtenke samo v dostopnostnih } \\
\text { nastavitvah. } \\
\text { Preverite, ali se barva ne uporablja kot } \\
\text { edino sredstvo za prenos informacij. }\end{array}$ & $\begin{array}{l}\text { Orodje za } \\
\text { barve }\end{array}$ \\
\hline
\end{tabular}




\begin{tabular}{|c|c|c|c|c|c|}
\hline Nadzor zvoka & 1.4 .2 & A & Razločljiv & $\begin{array}{l}\text { Preverite, ali ima vsak zvok, ki se } \\
\text { samodejno predvaja več kot tri sekunde, } \\
\text { način premora ali zaustavitve ali način za } \\
\text { nadzor glasnosti zvoka, neodvisno od } \\
\text { glasnosti sistema. }\end{array}$ & Ročno \\
\hline $\begin{array}{l}\text { Kontrast } \\
\text { (najmanjši) }\end{array}$ & 1.4 .3 & $\mathrm{AA}$ & Razločljiv & $\begin{array}{l}\text { Z orodjem za testiranje barvnega kontrasta } \\
\text { preverite, ali besedilo ni preveč svetlo, če } \\
\text { ga uporabljate na svetlem ozadju, ali preveč } \\
\text { temno, če ga uporabljate na temnem } \\
\text { ozadju. } \\
\text { Logotipi in besedila, ki so izključno } \\
\text { dekorativni, ne potrebujejo kontrastnega } \\
\text { testiranja. } \\
\text { Onemogočenim kontrolam ni treba } \\
\text { izpolnjevati kontrastnih zahtev. }\end{array}$ & $\begin{array}{l}\text { aXe } \\
\text { WAVE } \\
\text { aChecker } \\
\ldots\end{array}$ \\
\hline $\begin{array}{l}\text { Spreminjanje } \\
\text { velikosti } \\
\text { besedila }\end{array}$ & 1.4 .4 & $\mathrm{AA}$ & Razločljiv & $\begin{array}{l}\text { Povečava z dvema prstoma(Pinch-to-zoom) } \\
\text { bi morala povečati velikost besedila. } \\
\text { Če povečava z dvema prstoma (Pinch-to- } \\
\text { zoom) ne deluje, mora biti na voljo druga } \\
\text { metoda za spreminjanje velikosti besedila. } \\
\text { Omogočite velike velikosti besedila v } \\
\text { nastavitvah dostopnosti in preizkusite } \\
\text { izvorno aplikacijo, da preverite, ali je } \\
\text { besedilo mogoče povečati. }\end{array}$ & aXe \\
\hline Slike besedila & 1.4 .5 & $\mathrm{AA}$ & Razločljiv & $\begin{array}{l}\text { Slike besedil se ne smejo uporabljati. } \\
\text { Osredotočite se na vse slike besedila. } \\
\text { Preverite, ali imajo vse slike besedila isto, } \\
\text { točno in natančno alternativno besedilo. }\end{array}$ & Ročno \\
\hline Prerazporeditev & 1.4 .10 & $\mathrm{AA}$ & Razločljiv & $\begin{array}{l}\text { Ko je vsebina predstavljena } v \text { širini } 320 \\
\text { slikovnih pik, se izogiba horizontalnemu } \\
\text { drsenju ter ne prihaja do izgube vsebine ali } \\
\text { funkcionalnosti. } \\
\text { To pri večini spletnih mest zahteva } \\
\text { odzivno zasnovo. To je najbolje preizkusiti } \\
\text { tako, da nastavite okno brskalnika na } 1.280 \\
\text { pik in nato povečate vsebino strani na } 400 \\
\% \text {. } \\
\text { Vsebina, ki zahteva horizontalno drsenje, } \\
\text { je izvzeta. To so npr. podatkovne tabele, } \\
\text { zapletene slike (kot so zemljevidi in } \\
\text { grafikoni), orodne vrstice itd. }\end{array}$ & Ročno \\
\hline $\begin{array}{l}\text { Nebesedilni } \\
\text { kontrast }\end{array}$ & 1.4 .11 & $\mathrm{AA}$ & Razločljiv & $\begin{array}{l}\text { Za razlikovanje grafičnih objektov (kot so } \\
\text { ikone in komponente grafov ali } \\
\text { grafikonov) in komponent vmesnika po } \\
\text { meri (kot so gumbi, kontrole obrazca in } \\
\text { indikatorij/orisi ostrenja) obstaja } \\
\text { kontrastno razmerje vsaj } 3: 1 \text {. } \\
\text { Avtorsko prilagojene interaktivne } \\
\text { komponente morajo biti v različnih stanjih } \\
\text { (fokus, lebdenje, aktivno itd.) predstavljene } \\
\text { v kontrastnem razmerju vsaj } 3: 1 \text {. }\end{array}$ & Ročno \\
\hline $\begin{array}{l}\text { Medbesedilni } \\
\text { razmik }\end{array}$ & 1.4 .12 & $\mathrm{AA}$ & Razločljiv & $\begin{array}{l}\text { Ko uporabnik prilagodi razmik odstavkov } \\
\text { na dvakratno velikost pisave, višino } \\
\text { besedila/razmik besedila na 1,5-krat večjo } \\
\text { velikost pisave, razmik besed na 16-krat } \\
\text { večjo velikost pisave in razmik črk na } 12- \\
\text { kratno velikost pisave, ne pride do izgube } \\
\text { vsebine ali funkcionalnosti. }\end{array}$ & Ročno \\
\hline
\end{tabular}




\begin{tabular}{|c|c|c|c|c|c|}
\hline & & & & $\begin{array}{l}\text { To najlažje dosežemo s tem, da se } \\
\text { izogibamo definicijam višine slikovnih pik } \\
\text { za elemente, ki vsebujejo besedilo. }\end{array}$ & \\
\hline $\begin{array}{l}\text { Vsebina na } \\
\text { lebdenju ali } \\
\text { fokusu }\end{array}$ & 1.4 .13 & AA & Razločljiv & $\begin{array}{l}\text { Ko je dodatna vsebina predstavljena z } \\
\text { lebdenjem ali s fokusom tipkovnice: } \\
\text { - } \quad \text { Novorazkrita vsebina se lahko } \\
\text { zavrne (običajno s tipko Esc), ne } \\
\text { da bi premaknili kazalec ali fokus } \\
\text { tipkovnice, razen če vsebina } \\
\text { predstavlja napako pri vnosu ali če } \\
\text { ne zasenči ali moti druge vsebine } \\
\text { na strani. } \\
\text { - } \\
\text { Kazalec lahko premaknete na } \\
\text { novoprikazano vsebino, ne da bi } \\
\text { vsebina izginila. } \\
\text { - Nova vsebina mora ostati vidna, } \\
\text { dokler se kazalec ali fokus } \\
\text { tipkovnice ne odmakne od } \\
\text { sprožilnega elementa, nova } \\
\text { vsebina ni zavržena ali ni več } \\
\text { pomembna. }\end{array}$ & Ročno \\
\hline Tipkovnica & 2.1.1 & A & $\begin{array}{l}\text { Tipkovnično } \\
\text { dostopen }\end{array}$ & $\begin{array}{l}\text { Za iOS se pomikajte po aplikaciji in } \\
\text { aktivirajte vse kontrole uporabniškega } \\
\text { vmesnika z uporabo VoiceOver in } \\
\text { tipkovnice. } \\
\text { Za Android se pomikajte po aplikaciji in } \\
\text { aktivirajte vse kontrole uporabniškega } \\
\text { vmesnika samo s tipkovnico, torej brez } \\
\text { TalkBack funkcije. }\end{array}$ & Ročno \\
\hline $\begin{array}{l}\text { Brez } \\
\text { tipkovničnega } \\
\text { zastoja }\end{array}$ & 2.1 .2 & A & $\begin{array}{l}\text { Tipkovnično } \\
\text { dostopen }\end{array}$ & $\begin{array}{l}\text { Krmilite po vseh elementih } \mathrm{v} \text { aplikaciji in } \\
\text { preverite, ali se fokus nikoli ne zatakne. }\end{array}$ & Ročno \\
\hline Bližnjične tipke & 2.1.4 & A & $\begin{array}{l}\text { Tipkovnično } \\
\text { dostopen }\end{array}$ & $\begin{array}{l}\text { Če bližnjica na tipkovnici uporablja tipke } \\
\text { za tiskanje, potem mora biti uporabnik } \\
\text { sposoben onemogočiti ukaz tipke, } \\
\text { spremeniti tipko v tipko, ki je ni mogoče } \\
\text { tiskati (Ctrl, Alt, itd.) ali aktivirati bližnjico } \\
\text { samo, če je fokus na povezani komponenti } \\
\text { vmesnika ali gumbu. }\end{array}$ & Ročno \\
\hline $\begin{array}{l}\text { Nastavljiva } \\
\text { izbira časa }\end{array}$ & 2.2 .1 & A & Dovolj časa & $\begin{array}{l}\text { Pomikajte se po aplikaciji, vendar pustite } \\
\text { aplikacijo nekaj časa v prostem teku, dokler } \\
\text { se time-out ne aktivira. } \\
\text { Prepričajte se, ali obstaja opozorilo, preden } \\
\text { vas aplikacija preusmeri, ter ali lahko } \\
\text { podaljšate sejo, preden vas samodejno } \\
\text { odjavi. Preverite, ali lahko nastavitve } \\
\text { časovne omejitve prilagodite vsaj na 10- } \\
\text { krat daljši čas od privzetih nastavitev. } \\
\text { Razširitve časovnih omejitev ne veljajo za } \\
\text { izjeme v realnem času, kot so dražbe ali } \\
\text { časovno omejeni testi. }\end{array}$ & Ročno \\
\hline $\begin{array}{l}\text { Premor, } \\
\text { ustavitev, } \\
\text { skrivanje }\end{array}$ & 2.2 .2 & A & Dovolj časa & $\begin{array}{l}\text { Preverite, ali je vsebine, ki se premikajo, } \\
\text { utripajo ali samodejno posodabljajo, } \\
\text { mogoče začasno ustaviti, prekiniti ali skriti. }\end{array}$ & Ročno \\
\hline $\begin{array}{l}\text { Trije utripi ali } \\
\text { pod pragom }\end{array}$ & 2.3 .1 & A & $\begin{array}{l}\text { Napadi in } \\
\text { fizični odzivi }\end{array}$ & $\begin{array}{l}\text { Preverite, ali aplikacija nima elementov, ki } \\
\text { utripajo več kot trikrat na sekundo. }\end{array}$ & Ročno \\
\hline
\end{tabular}




\begin{tabular}{|c|c|c|c|c|c|}
\hline Obvod vsebine & 2.4 .1 & A & Krmljiv & $\begin{array}{l}\text { Preverite, ali obstaja metoda, kot je skip } \\
\text { link ali točki WAI-ARIA, ki uporabniku } \\
\text { omogočata, da obide bloke vsebine, ki se } \\
\text { ponavljajo na več straneh. } \\
\text { Uporabite ukaze za hitro navigacijo, da } \\
\text { obidete bloke vsebine. Preverite, ali lahko z } \\
\text { orientacijskimi točkami preskočite } \\
\text { navigacijo neposredno do glavne vsebine. }\end{array}$ & $\begin{array}{l}\text { aXe } \\
\text { WAVE } \\
\text { aChecker } \\
\ldots\end{array}$ \\
\hline $\begin{array}{l}\text { Stran } z \\
\text { naslovom }\end{array}$ & 2.4 .2 & A & Krmljiv & $\begin{array}{l}\text { Preverite, ali ima vsak zaslon } \mathrm{v} \text { aplikaciji } \\
\text { uporaben in edinstven naslov. }\end{array}$ & Ročno \\
\hline Fokusni red & 2.4 .3 & A & Krmljiv & $\begin{array}{l}\mathrm{Z} \text { uporabo kretenj ali tipkovnice krmilite } \\
\text { po vseh elementih } \mathrm{v} \text { aplikaciji in preverite, } \\
\text { ali so prebrani v pravilnem zaporedju. }\end{array}$ & $\begin{array}{l}\text { Ročno s } \\
\text { tipkovnico }\end{array}$ \\
\hline $\begin{array}{l}\text { Namen } \\
\text { povezave (v } \\
\text { kontekstu) }\end{array}$ & 2.4 .4 & A & Krmljiv & $\begin{array}{l}\text { Postavite fokus na vsako povezavo in } \\
\text { gumb ter preverite, ali je njegovo dostopno } \\
\text { ime, izgovorjeno na bralniku zaslona, } \\
\text { smiselno. } \\
\text { Preverite, ali je mogoče namen vsake } \\
\text { povezave ali gumba določiti samo na } \\
\text { podlagi njegovega besedila nalepke ali } \\
\text { besedila nalepke skupaj s programsko } \\
\text { določenim kontekstom povezave. }\end{array}$ & WAVE \\
\hline Več načinov & 2.4 .5 & $\mathrm{AA}$ & Krmljiv & $\begin{array}{l}\text { Prepričajte se, ali obstaja več načinov za } \\
\text { iskanje vsebine v aplikaciji s funkcijo } \\
\text { iskanja, kazala vsebine, zemljevida mesta ali } \\
\text { povezave na vse dele aplikacije na domači } \\
\text { strani. }\end{array}$ & Ročno \\
\hline $\begin{array}{l}\text { Naslovi in } \\
\text { oznake }\end{array}$ & 2.4 .6 & $\mathrm{AA}$ & Krmljiv & $\begin{array}{l}\text { Preverite, ali naslovi za organiziranje } \\
\text { vsebine, oznake za nadzor uporabniškega } \\
\text { vmesnika in vnosi obrazcev opisujejo } \\
\text { njihovo temo ali namen. }\end{array}$ & Ročno \\
\hline Viden fokus & 2.4 .7 & $\mathrm{AA}$ & Krmljiv & $\begin{array}{l}\text { Pomaknite se skozi vse elemente aplikacije } \\
\text { s tipkovnico in preverite, ali je fokus vedno } \\
\text { viden. } \\
\text { Preverite, ali element, ki je trenutno v } \\
\text { fokusu, vedno viden na zaslonu. }\end{array}$ & $\begin{array}{l}\text { Ročno s } \\
\text { tipkovnico }\end{array}$ \\
\hline Gibi kazalca & 2.5 .1 & A & $\begin{array}{l}\text { Modalitete } \\
\text { vnosa }\end{array}$ & $\begin{array}{l}\text { Če kretnje, ki uporabljajo več točk (na } \\
\text { primer ščipanje, drsenje ali vlečenje po } \\
\text { zaslonu), niso bistvene za funkcionalnost, } \\
\text { potem lahko funkcijo izvajate tudi z enim } \\
\text { samim točkovnim aktiviranjem (na primer } \\
\text { z aktiviranjem gumba). }\end{array}$ & Ročno \\
\hline Preklic kazalca & 2.5 .2 & A & $\begin{array}{l}\text { Modalitete } \\
\text { vnosa }\end{array}$ & $\begin{array}{l}\text { Da bi se izognili nenamernemu aktiviranju } \\
\text { kontrol, opustite nepotrebno aktiviranje ob } \\
\text { kliku, tapkanje ali dolgi pritisk } \\
\text { nepotrebnemu aktiviranju (npr. MouseDown } \\
\text { dogodek) ob kliku, tapkanju ali dolgem } \\
\text { pritisku na zaslon. Namesto tega uporabite } \\
\text { dogodek Click, MouseUp ali podobno. Če se } \\
\text { uporablja MouseUpali podobno, morate } \\
\text { zagotoviti mehanizem za prekinitev ali } \\
\text { razveljavitev izvedenega dejanja. }\end{array}$ & Ročno \\
\hline $\begin{array}{l}\text { Oznaka v } \\
\text { imenu }\end{array}$ & 2.5 .3 & A & $\begin{array}{l}\text { Modalitete } \\
\text { vnosa }\end{array}$ & $\begin{array}{l}\text { Če komponenta vmesnika (povezava, } \\
\text { gumb itd.) predstavlja besedilo (ali slike } \\
\text { besedila), mora dostopno ime (nalepka, } \\
\text { alternativno besedilo, nalepka ARIA itd.) } \\
\text { vključevati vidno besedilo. }\end{array}$ & $\begin{array}{l}\text { aXe } \\
\text { WAVE } \\
\text { aChecker } \\
\ldots\end{array}$ \\
\hline
\end{tabular}




\begin{tabular}{|c|c|c|c|c|c|}
\hline $\begin{array}{l}\text { Aktiviranje } \\
\text { gibanja }\end{array}$ & 2.5.4 & A & $\begin{array}{l}\text { Modalitete } \\
\text { vnosa }\end{array}$ & $\begin{array}{l}\text { Funkcionalnost, ki se sproži s premikanjem } \\
\text { naprave (kot je tresenje ali premikanje } \\
\text { mobilne naprave) ali s premikanjem } \\
\text { uporabnika (npr. mahanje pred kamero), } \\
\text { lahko onemogočite, enakovredna } \\
\text { funkcionalnost pa je zagotovljena s } \\
\text { standardnimi kontrolami, kot so gumbi. }\end{array}$ & Ročno \\
\hline Jezik strani & 3.1.1 & A & Berljiv & $\begin{array}{l}\text { Nastavite nastavitve govora bralnika } \\
\text { zaslona na privzeti jezik. } \\
\text { Postavite fokus na vsebino strani in bralnik } \\
\text { zaslona bi moral besedilo govoriti v } \\
\text { ustreznem sintetizatorju jezika. }\end{array}$ & $\begin{array}{l}\text { aXe } \\
\text { WAVE } \\
\text { aChecker } \\
\ldots\end{array}$ \\
\hline Jezik delov & 3.1 .2 & AA & Berljiv & $\begin{array}{l}\text { Nastavite nastavitve govora bralnika } \\
\text { zaslona na privzeti jezik. } \\
\text { Postavite fokus na dele strani v drugem } \\
\text { jeziku in bralnik zaslona bi moral besedilo } \\
\text { govoriti v ustreznem sintetizatorju govora, } \\
\text { npr. lang = »es« bo govoril s španskim } \\
\text { glasom bralca zaslona in ne z angleškim. }\end{array}$ & $\begin{array}{l}\text { aXe } \\
\text { WAVE } \\
\text { aChecker } \\
\ldots\end{array}$ \\
\hline V fokusu & 3.2.1 & A & Predvidljiv & $\begin{array}{l}\text { Nastavite fokus na vse komponente } \\
\text { aplikacije in preverite, ali ne pride do } \\
\text { spremembe konteksta, če komponenta } \\
\text { prejme fokus. }\end{array}$ & Ročno \\
\hline Na vhodu & 3.2 .2 & A & Predvidljiv & $\begin{array}{l}\text { Spremenite nastavitve vseh komponent } \\
\text { uporabniškega vmesnika in preverite, ali to } \\
\text { ne povzroči samodejne spremembe } \\
\text { konteksta, razen če je bil uporabnik pred } \\
\text { uporabo komponente opozorjen na to } \\
\text { spremembo. }\end{array}$ & Ročno \\
\hline $\begin{array}{l}\text { Dosledna } \\
\text { navigacija }\end{array}$ & 3.2 .3 & AA & Predvidljiv & $\begin{array}{l}\text { Krmilite po vseh zaslonih aplikacije in } \\
\text { preverite, ali se notranja navigacija izvaja v } \\
\text { enakem relativnem zaporedju in je } \\
\text { skladna. }\end{array}$ & Ročno \\
\hline $\begin{array}{l}\text { Dosledna } \\
\text { identifikacija }\end{array}$ & 3.2 .4 & AA & Predvidljiv & $\begin{array}{l}\text { Krmilite po vseh zaslonih aplikacije in } \\
\text { preverite, ali so komponente } \\
\text { uporabniškega vmesnika dosledno } \\
\text { opredeljene. }\end{array}$ & $\begin{array}{l}\text { Bralnik } \\
\text { zaslona }\end{array}$ \\
\hline $\begin{array}{l}\text { Identifikacija } \\
\text { napake }\end{array}$ & 3.3.1 & A & $\begin{array}{l}\text { Pomoč pri } \\
\text { vnosu }\end{array}$ & $\begin{array}{l}\text { V aplikaciji oddajte obrazce s praznimi in z } \\
\text { napačnimi podatki. } \\
\text { Preverite, ali so napake prepoznane, } \\
\text { opisane v besedilu in jih bralnik zaslona } \\
\text { izgovori. } \\
\text { Postavite fokus na vhode, ki imajo napake, } \\
\text { in preverite, ali bralnik zaslona izgovori } \\
\text { sporočila o napakah. }\end{array}$ & $\begin{array}{l}\text { aXe } \\
\text { WAVE } \\
\text { aChecker } \\
\ldots\end{array}$ \\
\hline $\begin{array}{l}\text { Oznake ali } \\
\text { navodila }\end{array}$ & 3.3.2 & A & $\begin{array}{l}\text { Pomoč pri } \\
\text { vnosu }\end{array}$ & $\begin{array}{l}\text { Postavite fokus na vsak nadzor vnosa } \\
\text { besedila in preverite, ali izgovorjena } \\
\text { nalepka vsebuje navodila za vnos } \\
\text { uporabnikom. } \\
\text { Postavite fokus na nadzornike obrazcev, ki } \\
\text { zahtevajo posebno oblikovan vnos } \\
\text { besedila, in preverite, ali bralec zaslona } \\
\text { izgovori vsa navodila za pravilno vnašanje } \\
\text { besedila. } \\
\text { Prepričajte se, ali so nalepke in navodila } \\
\text { vedno vidni tudi uporabniku z delujočim } \\
\text { vidom. }\end{array}$ & $\begin{array}{l}\text { aXe } \\
\text { WAVE } \\
\text { aChecker } \\
\ldots\end{array}$ \\
\hline
\end{tabular}




\begin{tabular}{|c|c|c|c|c|c|}
\hline $\begin{array}{l}\text { Nakazovanje } \\
\text { napake }\end{array}$ & 3.3 .3 & AA & $\begin{array}{l}\text { Pomoč pri } \\
\text { vnosu }\end{array}$ & $\begin{array}{l}\text { Postavite fokus na vhod, ki je bil } \\
\text { nepravilno oblikovan ali puščen prazen in } \\
\text { vam je sporočil napako. } \\
\text { Preverite, ali je viden primer ali predlog } \\
\text { pravilnega vnosa in njegovega formata ter } \\
\text { ali ga je bralnik zaslona izgovoril. }\end{array}$ & Ročno \\
\hline $\begin{array}{l}\text { Preprečevanje } \\
\text { napak (pravnih, } \\
\text { finančnih, } \\
\text { podatkovnih) }\end{array}$ & 3.3 .4 & AA & $\begin{array}{l}\text { Pomoč pri } \\
\text { vnosu }\end{array}$ & $\begin{array}{l}\text { To merilo uspeha velja za aplikacije z } \\
\text { dejanji, ki povzročajo pravne obveznosti in } \\
\text { finančne transakcije, ter aplikacije, ki } \\
\text { spremenijo ali izbrišejo uporabnikove } \\
\text { podatke v sistemih za shranjevanje } \\
\text { podatkov ali pošiljajo uporabnikove } \\
\text { odgovore na preizkuse znanja. } \\
\text { Preizkusite aplikacijo in preverite, ali so } \\
\text { vloge povratne, ali lahko uporabnik preveri } \\
\text { datum za napake pri vnosu in jih popravi } \\
\text { ter ali se informacije pregledajo, potrdijo in } \\
\text { popravijo, preden se oddaja dokumenta } \\
\text { zaključi. }\end{array}$ & Ročno \\
\hline Razčlenjevanje & 4.1.1 & A & Združljiv & $\begin{array}{l}\text { To merilo uspeha velja samo za aplikacije } \\
\text { za ogled spleta in jih je treba preizkusiti s } \\
\text { preverjanjem HTML. } \\
\text { Za to testiranje je priporočena uporaba } \\
\text { orodij, ki veljajo samo za vsebino HTML. }\end{array}$ & $\begin{array}{l}\text { aXe } \\
\text { WAVE } \\
\text { aChecker } \\
\ldots\end{array}$ \\
\hline $\begin{array}{l}\text { Ime, vloga, } \\
\text { vrednost }\end{array}$ & 4.1 .2 & A & Združljiv & $\begin{array}{l}\text { Postavite fokus na vse komponente } \\
\text { uporabniškega vmesnika, vključno z } \\
\text { elementi obrazca, s povezavami in z } \\
\text { JavaScript pripomočki, ter preverite, ali je } \\
\text { dostopno izgovorjeno ime smiselno in ali } \\
\text { ima element pravilno vlogo, stanje in } \\
\text { vrednost. } \\
\text { Preverite, ali izgovorjena vloga (povezava, } \\
\text { gumb itd.) pravilno ustreza funkcionalnosti } \\
\text { elementa. } \\
\text { Preverite, ali je izgovorjeno stanje elementa } \\
\text { (npr. } \\
\text { razširjen/zrušen/zatemnjen/onemogočen). } \\
\text { Preverite, ali je vrednost nastavljivega } \\
\text { elementa natančna. }\end{array}$ & $\begin{array}{l}\text { aXe } \\
\text { WAVE } \\
\text { aChecker } \\
\ldots\end{array}$ \\
\hline $\begin{array}{l}\text { Statusna } \\
\text { sporočila }\end{array}$ & 4.1 .3 & AA & Združljiv & $\begin{array}{l}\text { Če je predstavljeno pomembno sporočilo o } \\
\text { stanju in fokus ni nastavljen nanj, ga je } \\
\text { treba sporočiti uporabnikom bralnika } \\
\text { zaslona, običajno prek opozorila ARIA ali } \\
\text { z živo regijo. }\end{array}$ & $\begin{array}{l}\text { aXe } \\
\text { WAVE } \\
\text { aChecker } \\
\ldots\end{array}$ \\
\hline
\end{tabular}





\section{Seznam orodij za samodejno programsko preverjanje dostopnosti}

Splošni seznam, dosegljiv na W3C:

Web Accessibility Evaluation Tools List https://www.w3.org/WAI/ER/tools/

\section{Priljubljena brezplačna orodja:}

\begin{tabular}{|l|l|}
\hline aXe & $\begin{array}{l}\text { Tri različna orodja (DevTools, Auditor in Monitor) za } \\
\text { testiranje dostopnosti, pregled in nadzor nad statusom } \\
\text { dostopnosti posameznega spletišč - na voljo kot dodatek za } \\
\text { Google Chrome brskalnik. } \\
\text { https://www.deque.com/axe/ }\end{array}$ \\
\hline AChecker & $\begin{array}{l}\text { Orodje za preverjanje skladnosti posameznega spletnega } \\
\text { naslova (URL) s standardi dostopnosti. } \\
\text { https://achecker.ca/checker/index.php }\end{array}$ \\
\hline WAVE & $\begin{array}{l}\text { WAVE - Web Accessibility Evaluation Tool je skupina } \\
\text { evaluacijskih orodij, ki avtorjem pomaga pri zagotavljanju } \\
\text { dostopnosti v skladu s standardom WCAG. } \\
\text { https://wave.webaim.org/ }\end{array}$ \\
\hline Tingtun Checker & $\begin{array}{l}\text { Orodje za preverjanje skladnosti spletnih strani in datotek PDF } \\
\text { s standardi dostopnosti. http://checkers.wtkollen.se/ }\end{array}$ \\
\hline Access assistant & $\begin{array}{l}\text { Dodatki za brskalnike (Chrome, Firefox, Edge), ki opozarjajo } \\
\text { na elemente, če niso skladni s standardi dostopnosti. } \\
\text { https://webaccessibility.com/ }\end{array}$ \\
\hline $\begin{array}{l}\text { Colorblind Web } \\
\text { Page Filter }\end{array}$ & $\begin{array}{l}\text { Orodje za prikaz vpliva posamezne oblike barvne slepote na } \\
\text { prikaz spletne strani. } \\
\text { https://www.toptal.com/designers/colorfilter }\end{array}$ \\
\hline $\begin{array}{l}\text { Color Contrast } \\
\text { Checker }\end{array}$ & $\begin{array}{l}\text { Spletno orodje za preverjanje kontrasta med dvema barvama } \\
\text { (ozadje in besedilo). } \\
\text { https://webaim.org/resources/contrastchecker/ }\end{array}$ \\
\hline $\begin{array}{l}\text { SiteImprove } \\
\text { Accessibility Checker } \\
\text { Chrome Extension }\end{array}$ & $\begin{array}{l}\text { Dodatek za Google Chrome. } \\
\text { https://chrome.google.com/webstore/search/siteimprove }\end{array}$ \\
\hline ARCToolkit & $\begin{array}{l}\text { Dodatek za Google Chrome. } \\
\text { https://www.paciellogroup.com/toolkit/ }\end{array}$ \\
\hline Lighthouse & $\begin{array}{l}\text { Dodatek za Google Chrome. } \\
\text { https://chrome.google.com/webstore/search/lighthouse }\end{array}$ \\
\hline
\end{tabular}




\begin{tabular}{|l|l|}
\hline Functional & Spletno orodje za preverjanje dostopnosti spletišča omogoča \\
Accessibility & pregled večjega števila naslovov (URL). \\
Evaluator (FAE) & https:// fae.disability.illinois.edu/anonymous \\
\hline HiSoftware & Spletna aplikacija za pregled spletišča (standard WCAG 2.0). \\
CynthiaSays ${ }^{\mathrm{TM}}$ portal & http:// www.cynthiasays.com/ \\
\hline
\end{tabular}

\section{Plačljiva orodja}

\begin{tabular}{|l|l|}
\hline Siteimprove & $\begin{array}{l}\text { Profesionalna orodja za upravljalce spletišč vključujejo nadzor } \\
\text { nad dostopnostjo, optimizacijo SEO, varovanjem podatkov, } \\
\text { oglaševanjem, analitiko, zmogljivostjo .... } \\
\text { https://siteimprove.com/en }\end{array}$ \\
\hline Userway & $\begin{array}{l}\text { Dodatki za spletišča (Widget) omogočajo prilagajanje } \\
\text { parametrov prikaza strani, ki so pomembni za doseganje } \\
\text { dostopnosti. } \\
\text { https://userway.org/ }\end{array}$ \\
\hline
\end{tabular}

\section{Drugo}

\begin{tabular}{|l|l|}
\hline $\begin{array}{l}\text { Accessibility Tools - } \\
\text { članek }\end{array}$ & $\begin{array}{l}\text { Obsežen članek s povezavami do različnih orodij za odpravo } \\
\text { posameznih težav z dostopnostjo. } \\
\text { https://uxdesign.cc/accessibility-tools-and-tips-for-designers- } \\
\text { 1b8eea599c5d }\end{array}$ \\
\hline
\end{tabular}




\section{Priloga 4}

\section{Predloga za poročilo o hevrističnem ocenjevanju}

\section{Povzetek}

Poročilo opisuje skladnost spletišča [www ...] z zahtevami o dostopnosti, kot jih določa Zakon o dostopnosti spletišč in mobilnih aplikacij (ZDSMA).

Opravljen je bil pregled skladnosti spletišča UPRS, ki je potekal v skladu s harmoniziranim standardom SIST EN 301549 V1.1.2 in Smernicami za dostopnost spletnih vsebin WCAG 2.1. Pregled je obsegal podrobno analizo, samodejno testiranje in ročni pregled spletišča ter preverjanje izpolnjevanja zahtev glede dostopnosti v skladu z določili ZDSMA. Postopek pregleda je temeljil na virih za preverjanje dostopnosti organizacije W3C in je opisan v poglavju 6.

$\mathrm{Na}$ podlagi opravljenega pregleda in preverjanja skladnost z zahtevami o dostopnosti je spletišče $[w w w . . .]<$. skladno/delno skladno/neskladno $>\mathrm{z}$ določili ZDSMA in merili WCAG 2.1 za doseganje ravni skladnosti AA, ki je predpisana $s$ harmoniziranim standardom SIST EN 301549 V1.1.2.

\section{Ozadje ocenjevanja}

Preverjanje dostopnosti spletišča se izvaja z uporabo samodejnih in polsamodejnih orodij ter postopkov za preverjanje skladnosti in $z$ ročnim pregledom izkušenih ocenjevalcev.

Poročilo predstavlja rezultate pregledov, ki so potekali v obdobju med ... in . Pregled je obsegal vse spletne naslove, dostopne s povezav na spletišču.

Vsebina spletišča se dnevno spreminja, zato so po zadnjem opravljenem pregledu mogoča odstopanja od ugotovitev pregleda.

Uporabnikom in obiskovalcem, ki se soočajo z nedostopnostjo spletišča, je smiselno omogočiti čim enostavnejše posredovanje obvestil o morebitnih neskladnosti spletišča z določili ZDSMA in težavah pri dostopu do spletnih vsebin na spletišču. Ena od možnosti, poleg elektronske pošte in telefonske številke, je namenski kontaktni obrazec za posredovanje obvestil. 


\section{Obseg ocenjevanja}

Pregled skladnosti je obsegal celotno spletišče [www ...].

Naslov spletišča: http://www ...

Jezik spletišča: slovenski.

Ob pregledu dne ... je spletišče obsegalo ... elementov, od tega ... spletnih naslovov (angl. Uniform Resource Locations - URLs) in ... spletnih naslovov brez matičnega direktorija, kar pomeni, da teh spletnih strani ni bilo mogoče uvrstiti v hierarhijo spletišča in obiskovalcem spletišča, zato niso neposredno dostopne. Strukturo spletišča [www ...] za štiri ravni prikazuje spodnja slika.

Datumi opravljenih samodejnih pregledov: ... Ročno pregledovanje je potekalo v času od ... do ... Priprava analize je potekala $\mathrm{v}$ času od ... do ...

\section{Ocenjevalci}

Pregled skladnosti je izvajal ... Kontaktni podatki:

Seznam vodilnih ocenjevalcev :

Materni jezik ocenjevalcev je slovenski.

Strokovno znanje in izkušnje ocenjevalcev: 


\section{Postopek ocenjevanja}

Ocenjevalci so ocenjevali skladnost spletišča [www ...] s harmoniziranim standardom SIST EN 301549 V1.1.2 in predpisanimi smernicami za dostopnost spletnih vsebin WCAG 2.1 ter doseganje zahtevane ravni AA skladu z naslednjim koraki:

- testiranje spletišča s samodejnimi orodji - samodejno orodje pregleda spletišče in poišče težave pri zagotavljanju dostopnosti in neizpolnjevanje zahtev o dostopnosti, kot jih določajo smernice za dostopnost spletnih vsebin WCAG 2.1;

- pregled spletišča - strokovnjaki simulirajo uporabniško izkušnjo pri uporabi spletišča;

- pregled spletišča z orodji - strokovnjaki z orodji in s podpornimi tehnologijami preverijo, kako dostopni so različni deli spletišča in kako se odzivajo na uporabljena orodja;

- pregled kode - ocenjevalci pregledajo kodo spletišča, da poiščejo težave v zvezi z dostopnostjo;

- uporabniško testiranje - pri ocenjevanju dostopnosti spletišč sodelujejo uporabniki z različnimi oviranostmi, ki najbolje poznajo ovire pri dostopu do spletnih vsebin in podporne tehnologije, ki jih pri tem uporabljajo, kot so bralniki zaslona ali povečevalniki zaslonske slike.

Pri ocenjevanju dostopnosti spletišč naši ocenjevalci uporabljajo vodilna orodja za ocenjevanje dostopnosti, kot so ...

Velik delež od skupno 50 meril uspešnosti WCAG 2.1 je mogoče preveriti le z ročnim preverjanjem. Potencialne težave, ki so jih samodejna orodja označila za ročni pregled, smo preverili ročno, pri čemer smo ponavljajoče se težave preverjali samo enkrat.

\section{Rezultati in predlogi za reševanje}

Po opravljen samodejnem in ročnem pregledu je bila dosežena -odstotna skladnost. Povprečno je na spletno stran ostalo napak.

V Preglednici št. 1 je predstavljen pregled doseganja zakonske skladnosti spletišča UPRS.SI z zahtevami o dostopnosti in s smernicami WCAG 2.1 za predpisano raven A in AA. 
Preglednica 1: Skladnost spletišča UP-RS-SI z WCAG 2.1 — raven skladnosti A in AA

\begin{tabular}{|l|l|l|}
\hline Kriterij uspešnosti & Raven & Skladnost* \\
\hline ZAZNAVNOST & & \\
\hline Besedilna nadomestila & & \\
\hline 1.1.1 Nebesedilna vsebina & A & ni skladno/delno skladno/skladno \\
\hline Časovni mediji* & & \\
\hline 1.2.1 Samo avdio in samo video (predposneto) & A & ni skladno/delno skladno/skladno \\
\hline$\ldots$ (Priloga 1) & & \\
\hline
\end{tabular}

* Na podlagi 2. odstavka 3. člena ZDSMA se zakon ne uporablja za predhodno posnete medijske vsebine, objavljene pred 23. septembrom 2020.

\section{Reference}

\section{Priloge}

- Predlogi ukrepov

$-\ldots$

Vir: Template for Accessibility Evaluation Reports:

https://www.w3.org/WAI/test-evaluate/report-template/ 
Primer izjave o dostopnosti

\section{Izjava o dostopnosti}

Obiskovalcem našega spletnega mesta želimo, da se počutite dobrodošli in dobro uporabniško izkušnjo.

\section{Trud za dostopnost spletnega mesta}

Da bi zagotovili pozitivno uporabniško izkušnjo spletnega mesta UKM za vse spletne uporabnike, smo pri izdelavi sledili smernicam WCAG 2.1 (angl. Web Content Accessibility Guidelines (WCAG) 2.1). Te pojasnjujejo, kako zagotoviti, da so spletne vsebine dostopne osebam z omejitvami in uporabniško prijazne za vse.

Smernice opredeljujejo tri ravni dostopnosti (A, AA in AAA). Na spletnem mestu UKM zagotavljamo minimalno skladnost ravni AA, ki je nadgrajena s posameznimi zahtevami ravni AAA. Te predvsem osebam z okvarami vida omogočajo še boljšo uporabniško izkušnjo.

\section{Stanje dostopnosti}

V dostopnost spletnega mesta UKM smo vložili veliko truda in menimo, da smo dosegli zastavljeni cilj skladnosti ravni AA.

Prek spletnega mesta je na voljo veliko število dokumentov, za katere se trudimo, da so v dostopni obliki.

Vsebine spletnih strani redno spremljamo in se trudimo zagotavljati skladnost, a če vseeno naletite na težavo, nas, prosimo, obvestite. 
Posebne funkcije dostopnosti

Spletno mesto vam omogoča:

- poenostavitev strukture,

- izbiro barvne teme,

- izbiro pisave,

- poudarjen fokus,

- krepko pisavo,

- uporabo funkcij brskalnika za povečavo.

\section{Povejte nam, kaj mislite}

Če ste imeli težave pri uporabniški izkušnji s spletnim mestom UKM, nam težavo sporočite prek obrazca Prijava nedostopne vsebine ali na elektronski naslov ukm@um.si. 


\section{Gibalno ovirani}

\begin{tabular}{|c|c|c|}
\hline \multicolumn{2}{|c|}{ Digitalni pripomočki } & 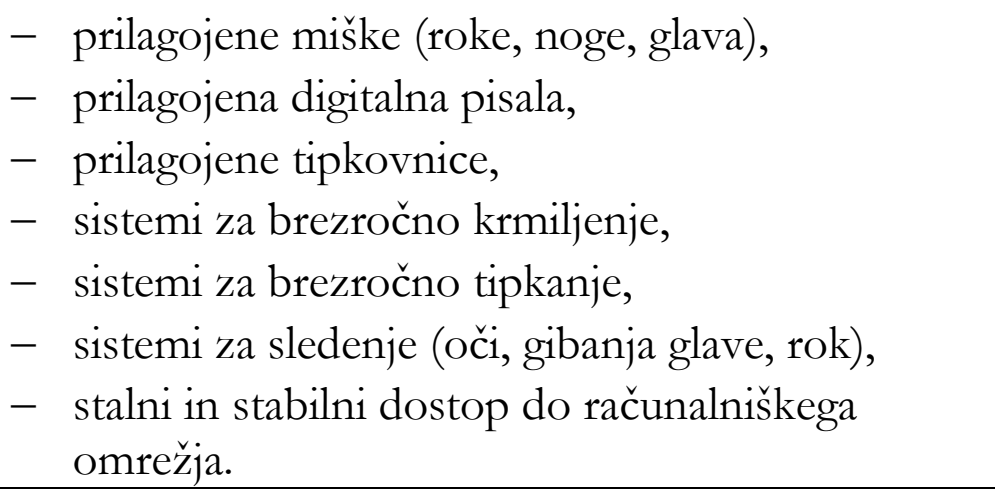 \\
\hline \multicolumn{2}{|l|}{ Ostali pripomočki } & $\begin{array}{l}\text { - } \text { prilagoditveni stol, miza, } \\
\text { - } \text { dvigala za stopnice, } \\
\text { - } \text { klančine, } \\
\text { - } \text { prilagojene ovire na javni poti (robniki, stopnice) } \\
\text { ter uporaba objektov v javni rabi, } \\
\text { - } \text { ustrezno prilagojeno delovno okolje za doseg } \\
\text { vseh potrebnih upravljalnikov (višina, globina, } \\
\text { stranski premiki ...). }\end{array}$ \\
\hline \multirow[t]{2}{*}{$\begin{array}{l}\text { Potrebe glede na } \\
\text { načela: }\end{array}$} & & \\
\hline & zaznavnost & $\begin{aligned} \text { - } & \text { izvajanje aktivnosti brez tipkovnice, } \\
\text { - } & \text { dostop brez govorjenja, } \\
\text { - } & \text { biometrične metode za izvajanje aktivnosti, } \\
\text { - } & \text { vizualni status trenutne aktivnosti, } \\
\text { - } & \text { standardne povezave z omrežjem - stalne in } \\
& \text { stabilne, } \\
\text { - } & \text { prikaz možnosti ponavljanja vnosa, } \\
\text { - } & \text { prikaz možnosti dvojnega vtipkavanja, } \\
\text { - } & \text { orientacija v aplikaciji mora biti jasno razvidna, } \\
- & \text { nujne informacije v zvočnem in besedilnem } \\
& \text { načinu, } \\
- & \text { dostopna dokumentacija, } \\
\text { - } & \text { ponudba predlog za minimalno dopolnjevanje v } \\
& \text { različnih aplikacijah, } \\
\text { - } & \text { samodejna ponudba poti brez ovir (navigacija na } \\
& \text { poti, v aplikaciji). }\end{aligned}$ \\
\hline
\end{tabular}




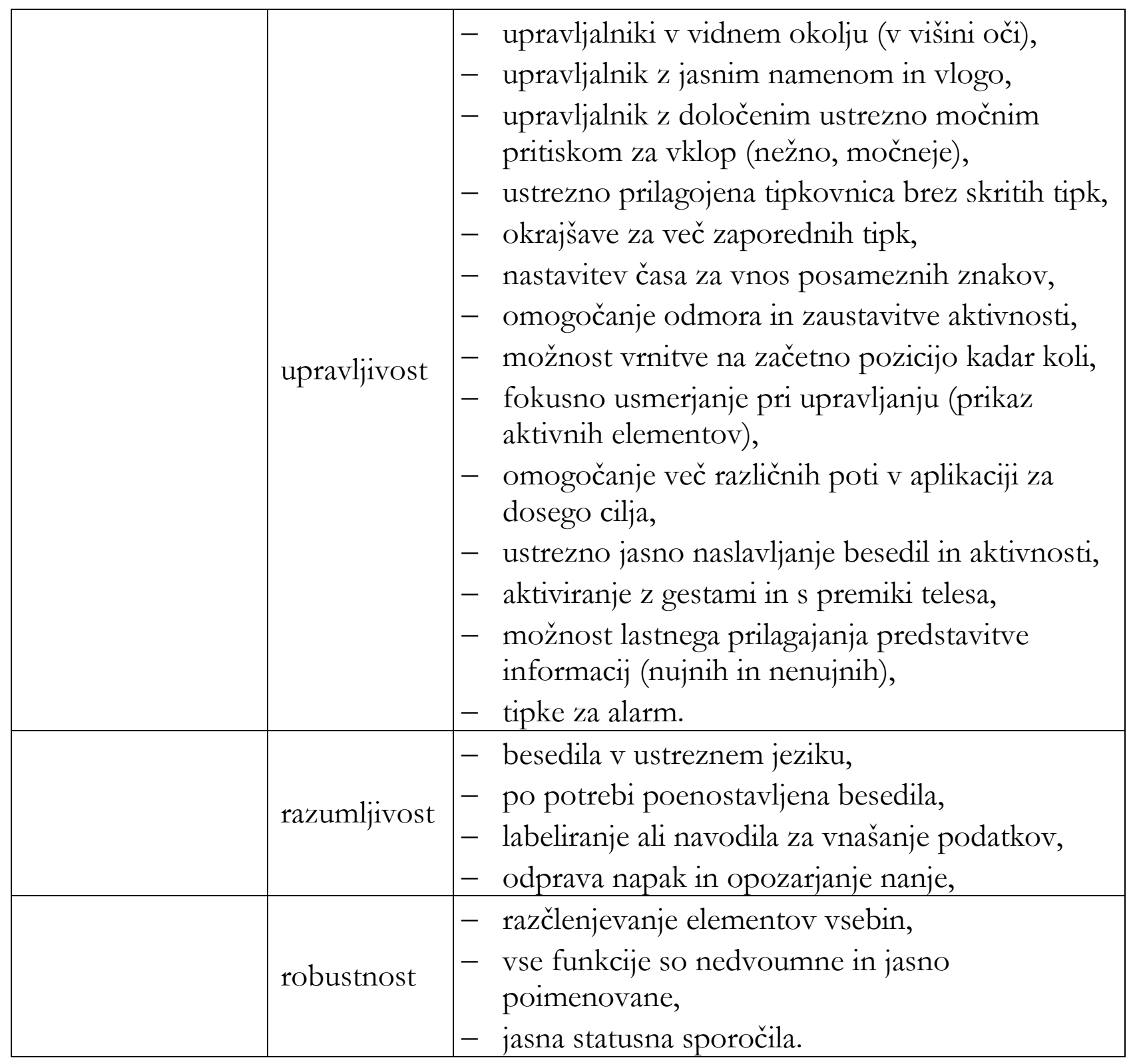

\section{Slepi in slabovidni}

\begin{tabular}{|l|l|}
\hline & - braillova tipkovnica, \\
- & govorni sintetizator, \\
- & bralnik zaslona, \\
- & povečevalnik zaslona, \\
Digitalni pripomočki & zaslon z nastavitvami barv, kontrastov, \\
& svetilnosti, \\
- & glasovni vodnik, \\
- & sistemi za brezročno tipkanje, \\
- & senzorji gibanja, \\
- & numerične tipkovnice, \\
- & digitalni ključi in karte, \\
\hline
\end{tabular}




\begin{tabular}{|c|c|c|}
\hline & & $\begin{array}{l}\text { - taktilni indikatorji (angl. tudi beacons) za zvok in } \\
\text { situacije, } \\
\text { - stalni in stabilni dostop do računalniškega } \\
\text { omrežja. }\end{array}$ \\
\hline \multicolumn{2}{|l|}{ Ostali pripomočki } & $\begin{array}{l}\text { - urejeni prostori in poti brez ovir na tleh in } \mathrm{v} \\
\text { višini glave, } \\
\text { - } \text { zvočni signalniki v javnem prometu (dvigala, } \\
\text { semaforji, signalizacija), } \\
\text { - } \text { simboli v braillovi pisavi (v dvigalih, na postajah } \\
\text {...), } \\
\text { - } \\
\text { - } \\
\text { - tušalke in za večkanalno poslušanje, } \\
\text { - } \\
\text { stalni dostop do Interneta. }\end{array}$ \\
\hline \multicolumn{3}{|l|}{$\begin{array}{l}\text { Potrebe glede na } \\
\text { načela: }\end{array}$} \\
\hline & zaznavnost & $\begin{array}{l}\text { - podpora nevizualni zaznavi (zvočno, taktilno), } \\
\text { - zvočni izhod (skupaj z govorom), } \\
\text { - opisi zvoka, } \\
\text { - } \text { samodejno popravljanje računalniško podprtega } \\
\text { govora, } \\
\text { - nadzor nad zvokom (zaustavitev, glasnost), } \\
\text { - govorni izhod za nebesedne, slikovne in video } \\
\text { medije, } \\
\text { - določitev jezika govora, } \\
\text { - nevizualna identifikacija napak, } \\
\text { - zvok za dokazovanje plačevanja, } \\
\text { - povečevanje besedil in znakov, } \\
\text { - nebesedilni kontrast, } \\
\text { - zamiki v besedilu, } \\
\text { - izvajanje aktivnosti brez tipkovnice, } \\
\text { - } \text { biometrične metode za izvajanje aktivnosti, } \\
\text { - prikaz taktilnega ali zvočnega statusa, } \\
\text { - prikaz delujočega dela produkta v različnih } \\
\text { modalitetah, } \\
\text { - prikaz številke kličočega, } \\
\text { - alternative za video podprte storitve, } \\
\text { - podnapisi - določitev značilnosti in } \\
\text { prilagoditve, } \\
\text { - govorjeni podnapisi, } \\
\text { - sinhronizacija, predvajanje in shranjevanje } \\
\text { zvoka, }\end{array}$ \\
\hline
\end{tabular}




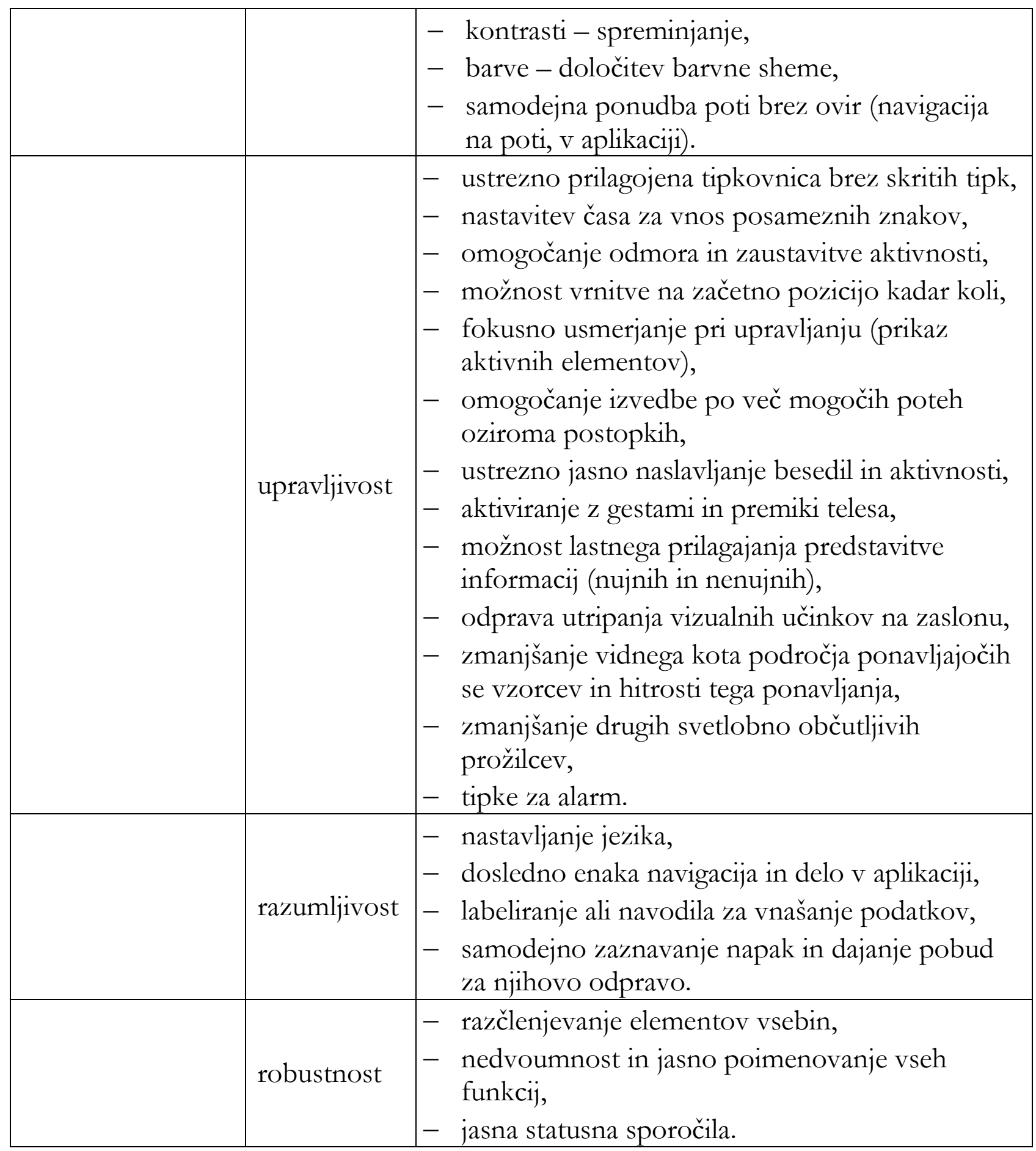

\section{Gluhi in naglušni}

\begin{tabular}{|l|l|}
\hline \multirow{5}{*}{ Digitalni pripomočki } & - podnapisi, \\
& - video tolmača znakovnega jezika, \\
- & transkript, \\
- & ojačevalci zvoka, \\
- & sistemi za povezovanje zvočnih sistemov s \\
& slušnimi aparati (sistem FM in indukcijska \\
& zanka), \\
\hline
\end{tabular}




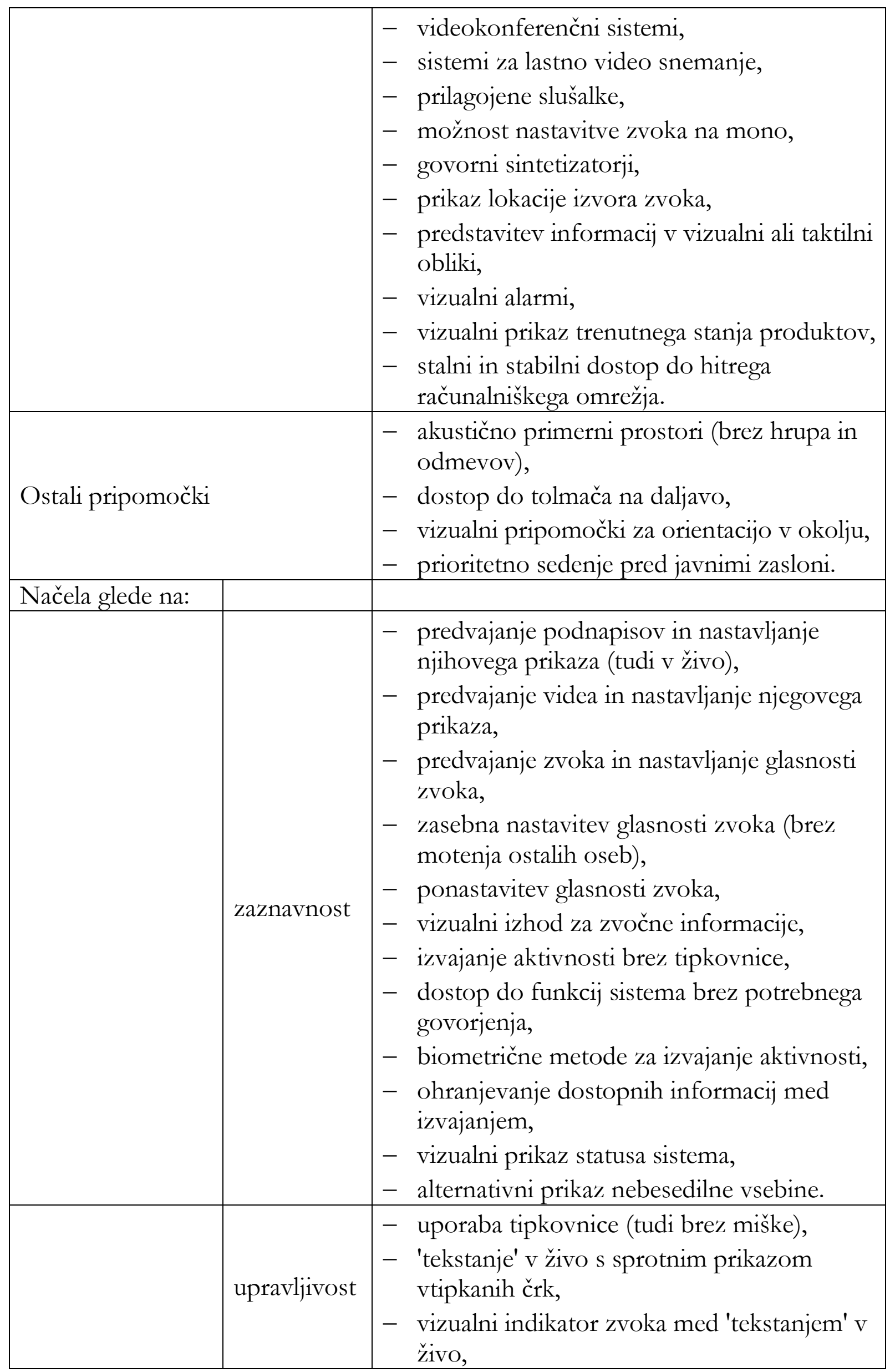




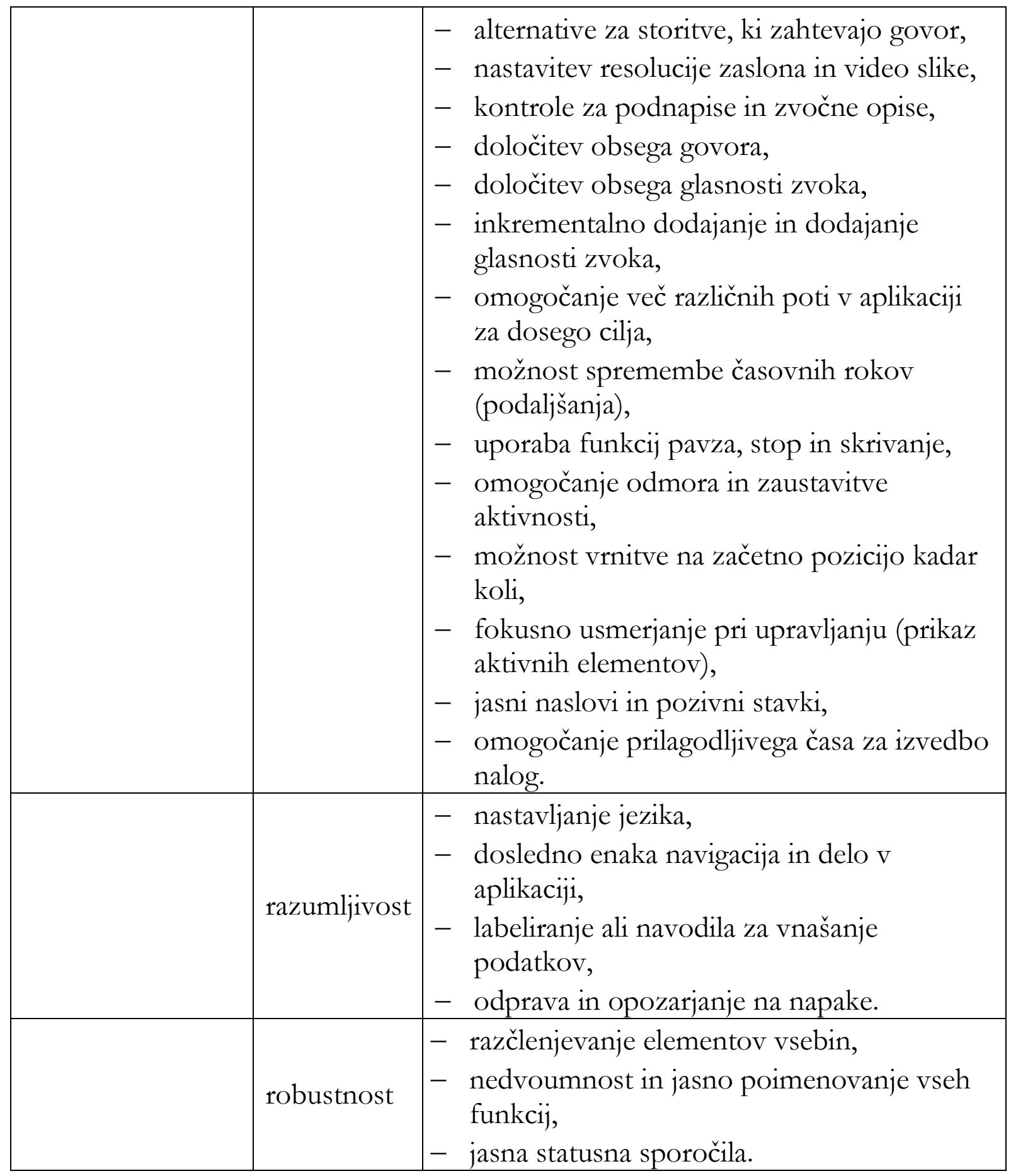

Osebe s težavami v kognitivnem funkcioniranju

\begin{tabular}{|l|l|}
\hline \multirow{2}{*}{ Digitalni pripomočki } & - podnapisi, \\
& - transkript, \\
& - ojačevalci zvoka, \\
& - sistemi za lastno video snemanje, \\
& - prilagojene slušalke, \\
& - govorni sintetizatorji, \\
\hline
\end{tabular}




\begin{tabular}{|c|c|c|}
\hline & & 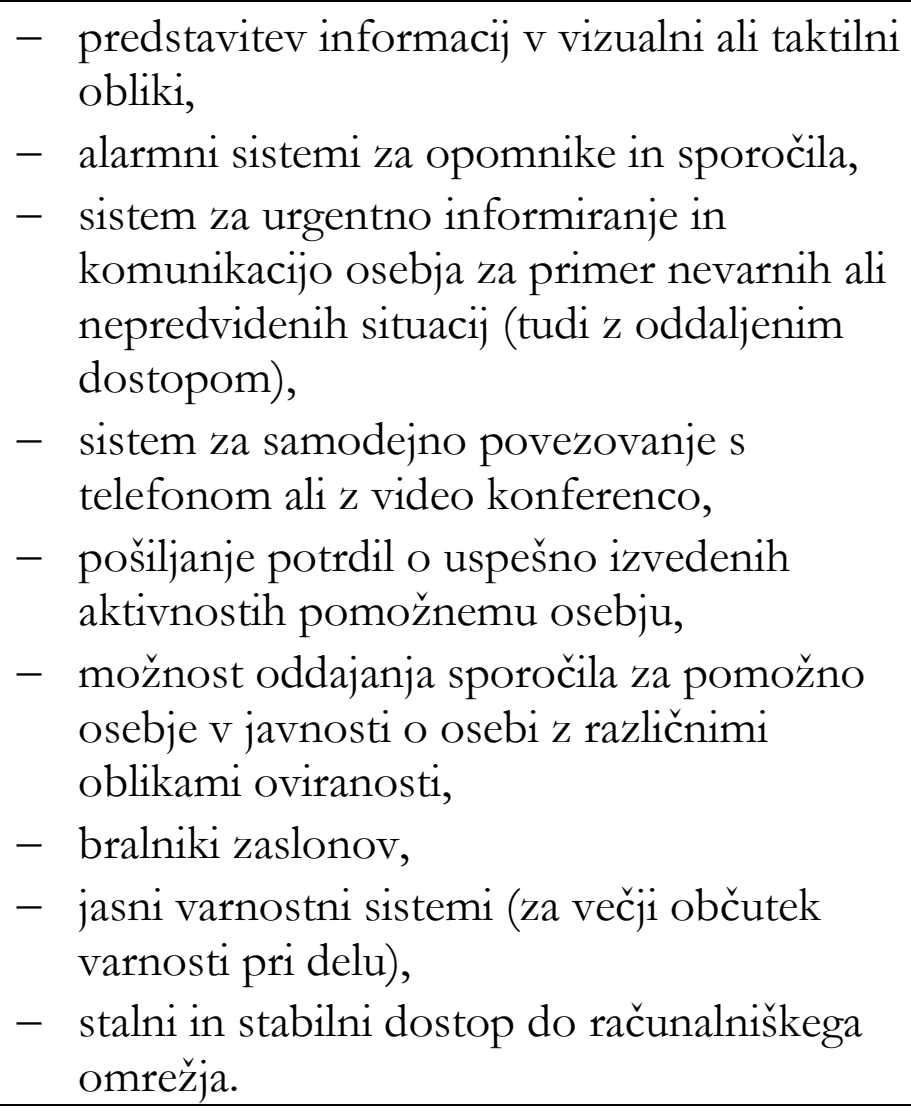 \\
\hline Ostali pripomočl & & $\begin{array}{l}\text { - akustično primerni prostori (brez hrupa in } \\
\text { odmevov), } \\
\text { - vizualni pripomočki za orientacijo v okolju, } \\
\text { - } \text { prioritetno sedenje pred javnimi zasloni, } \\
\text { - } \\
\text { sistem za ponavljanje prenašanja sporočil } \\
\text { do potrditve prejema. }\end{array}$ \\
\hline Načela glede na: & & \\
\hline & zaznavnost & 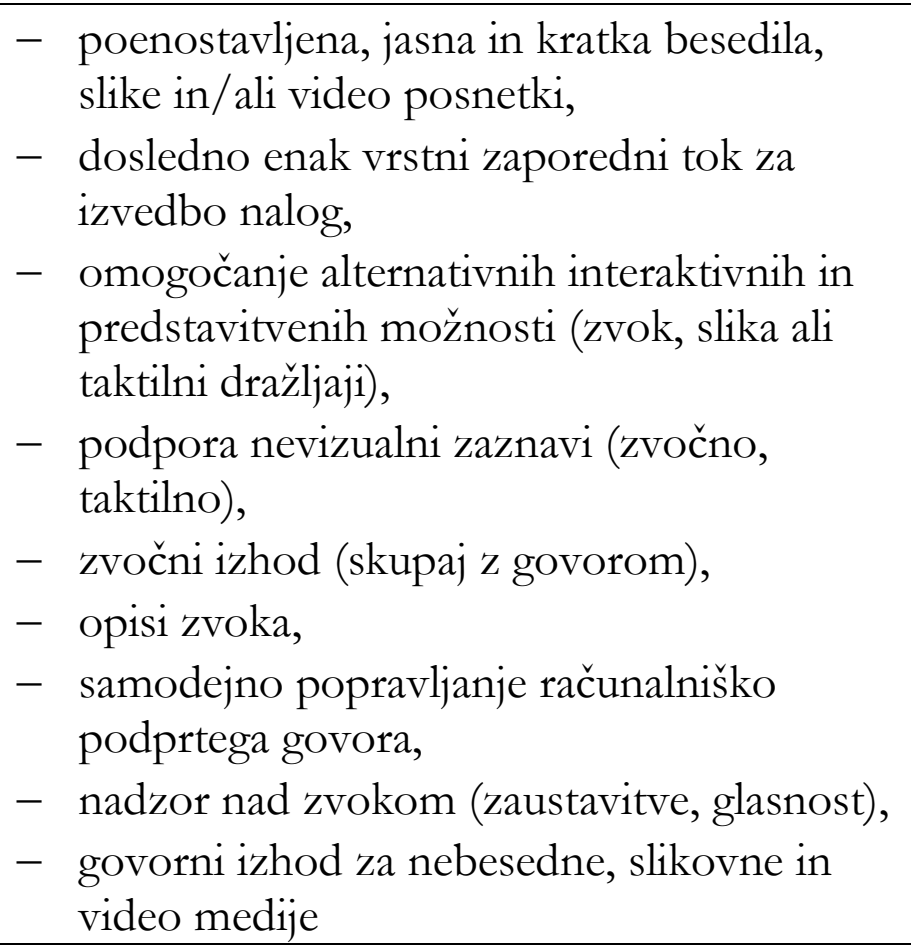 \\
\hline
\end{tabular}




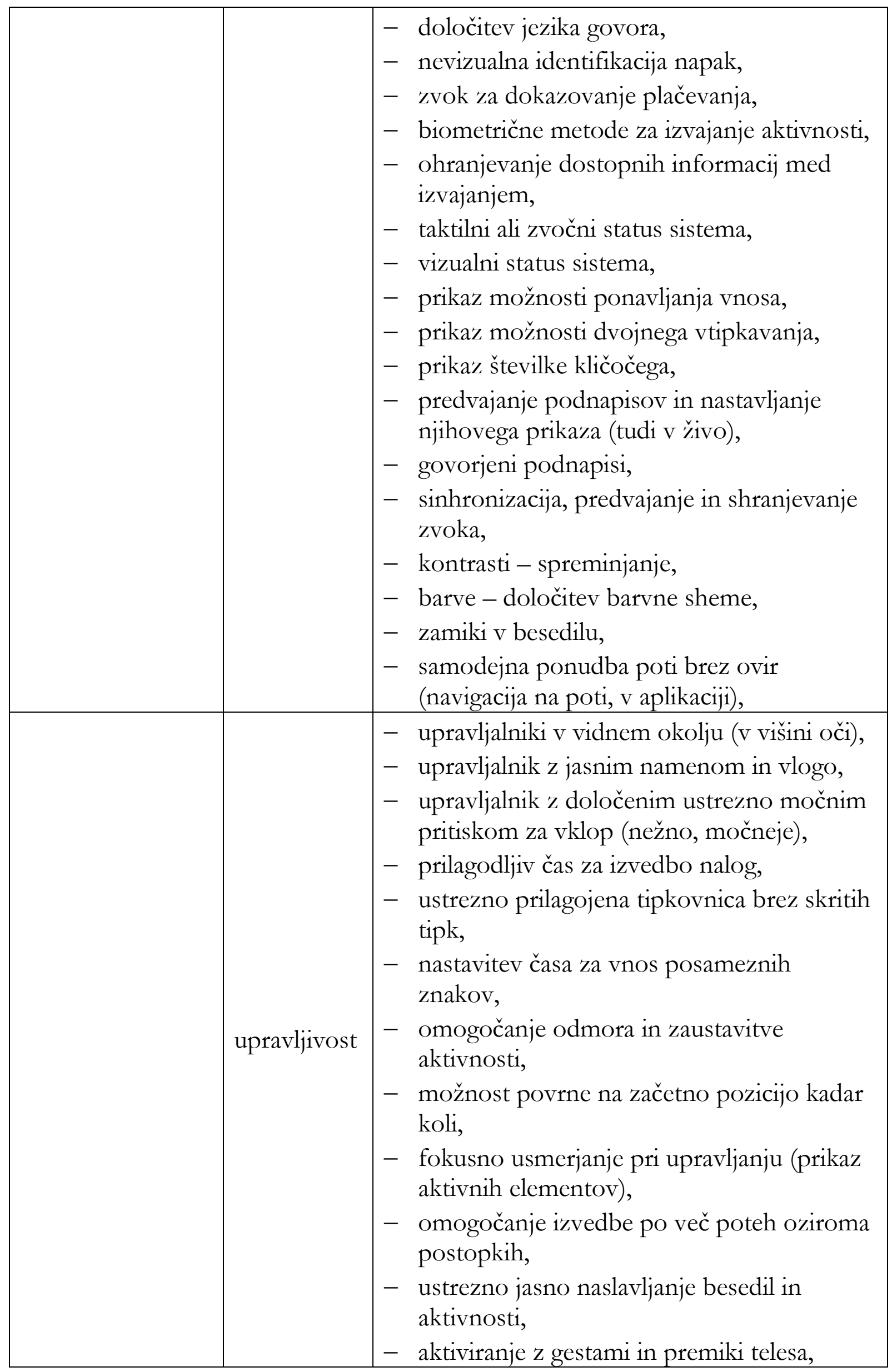




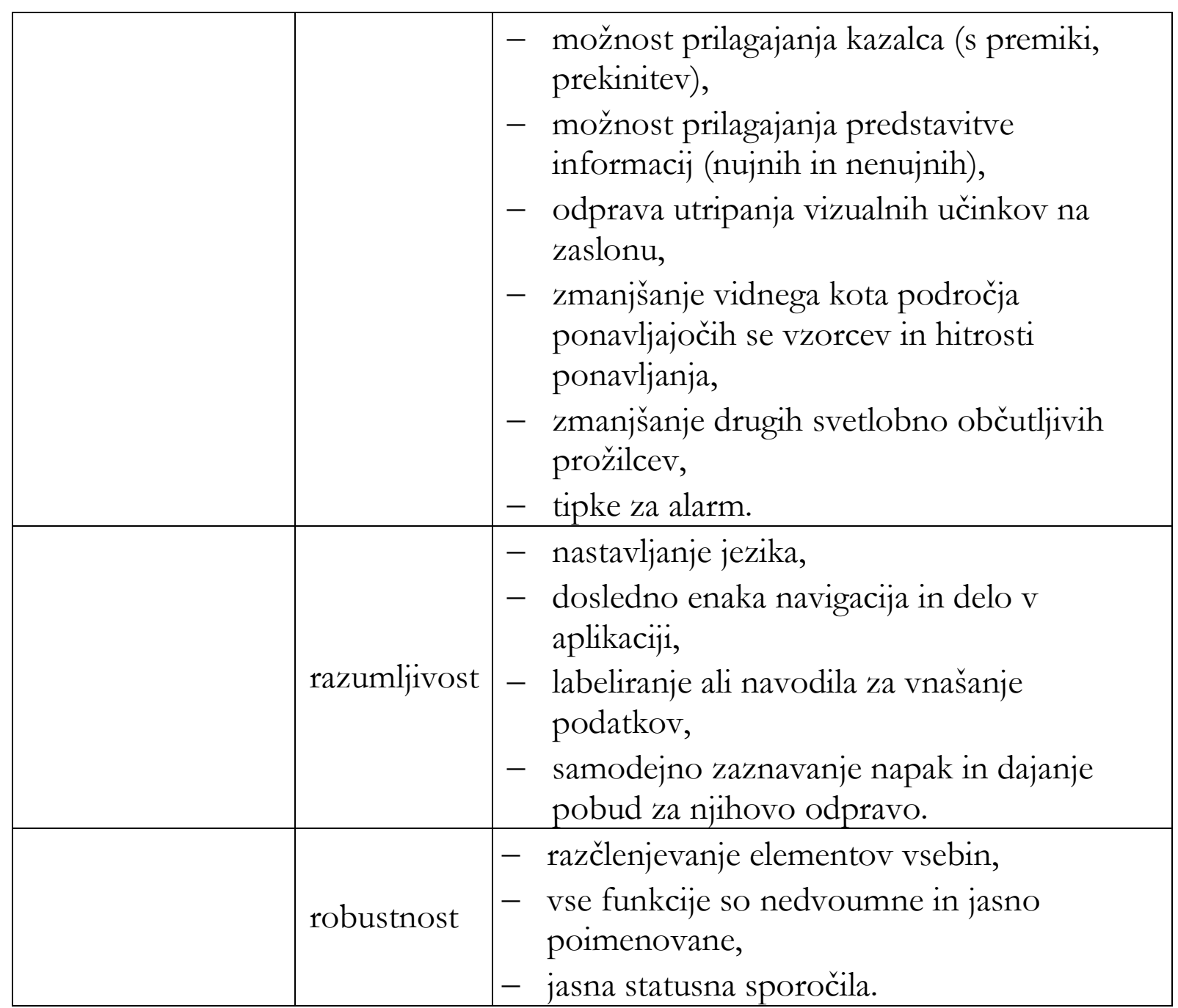





\title{
DOSTOPNOST DIGITALNIH
}

\section{PRODUKTOV ZA VSE}

\author{
MATJAŽ DEBEVC \\ Univerza v Mariboru, Fakulteta za elektrotehniko, računalništvo in informatiko, Maribor, \\ Slovenija. E-pošta: matjaz.debevc@um.si
}

Povzetek Dostopnost produktov $\mathrm{v}$ okviru informacijske in komunikacijske tehnologije postaja s širjenjem kroga uporabnikov tudi na osebe $z$ različnimi oblikami oviranosti pomemben dejavnik pri analizi, izdelavi in ocenjevanju računalniških aplikacij, spletnih strani in mobilnih aplikacij. Monografija predstavlja pomemben korak pri osveščanju, izobraževanju in usposabljanju vseh oseb, ki se srečajo z vprašanjem, zakaj in kako pripraviti ustrezno prilagojene aplikacije in produkte, da bodo dostopni vsem. V delu so zajete osnove, ki so potrebne za to, da lahko vsak analitik, razvojnik in ocenjevalec najde oporne točke za svoje delo, kjer mora upoštevati zahteve in potrebe oseb z različnimi oblikami oviranosti. Poleg značilnosti in zahtev so navedene tudi mogoče rešitve oziroma potrebe, ki jih lahko uporabimo za prilagojene aplikacije in produkte. Zajeta so osnovna pravila in načela dostopnosti ter priporočila, kot sta WCAG in standard ETSI EN 301 549. Podani so primeri dobre in slabe prakse, da bralec lažje ugotovi in preveri ustreznost svojega predloga glede na tipe oseb z različnimi oblikami oviranosti. Monografija se zaključi z metodami ocenjevanja in preverjanja dostopnosti digitalnih produktov, skupaj s pripomočki za hiter in enostaven pregled po posameznih kriterijih uspešnosti.

Ključne besede: dostopnost, spletne strani, mobilne aplikacije, analiza, oblikovanje spletnih strani, ocenjevanje, WCAG. 
10110000110110001111101101110110001010000000111 00010110000110110001111101101110110001010000000 11000011011000111110110111011000101000000011100 $011000111110110111011000: 10100000001110000110001$ 0001101:1000111110110111011000101000000011100001 01100001101100011111011011101100010100000001110 01101100011111011011101100010100000001110000110 11000111110110111011000101000000011100001100011 10001011000011011000111110110111011000101000000 1100001101100011111011011101100010100000011100 $10000^{* 11011000111110110111011000101 * 0000000111000}$ 00110110081111101101110110001010000000111000011 $01100001101100011111011011^{*} 101100010100000001110$ 00101100001101100011111011011101100010100000001

* 10000110110001111101101110110001010000000111000

•. $\quad 11000111110110111011000101000000 \$ 11100001100011$ 00110110001111101101210110001010000000111000011 1011000011011000,1111101101110110001010000000111 00010110000110110001111101101110110001010000000

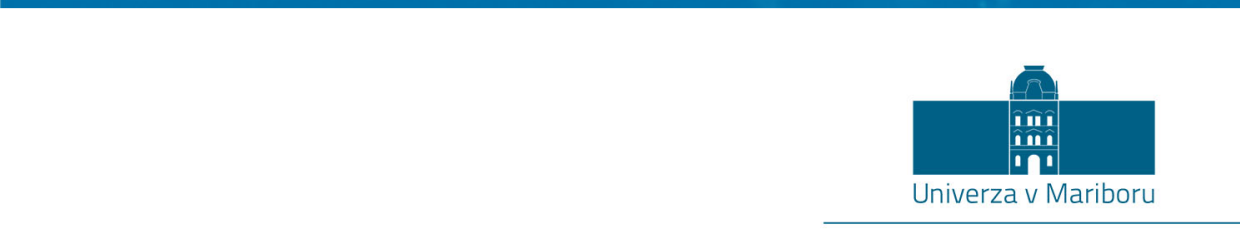

Fakulteta za elektrotehniko, računalništvo in informatiko

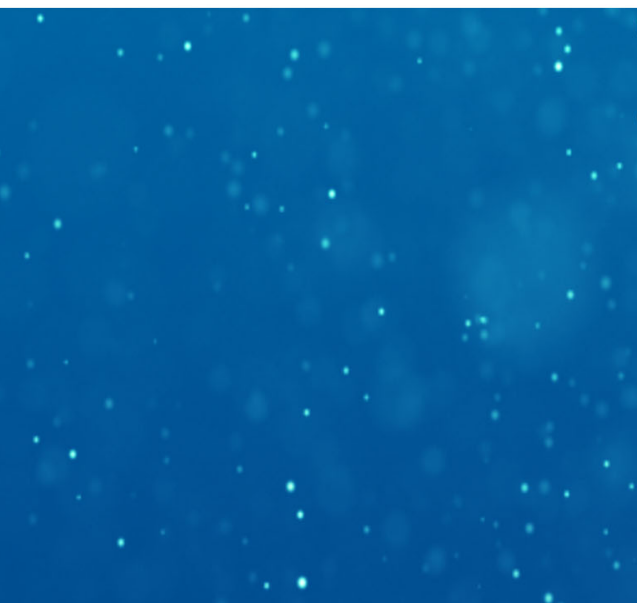

0010110000110110001 111011011101100010100000001 10000110110001111101101110110001010000000111000 11000111110110111011000101000000011100001100011 00110110001111101101110110001010000000111000011 10110000110110001111101101110110001010000000111

· 0001011000011011000111110110111011000401000000 110000110110001111101102110110001010000001110 \& $01^{1} 100011111011011101100010100000001110000110001$ 0001101100011111011011101100010100000001110000 01100001101100011111011011101100010100000001110 011011000111110110111011000101000000011100001 $110001111101 \% 1110110001010000001110000110001$ $100010110000110110001111^{*} 10110111011000101000000$ 11000011011000111110110111011000101000000011100 1000011011000111101101110110001010000000111000 $.001101100011111011011101,000101006000011,1000011$ 01100001101100011111011011101200010100000001110 00101100001101100011111011011101100010100000,001

10000110110001111101101110110001010000000111000 11000111110110111011000101000000011100001100011

- 001101100011111011011101100010100000001110000 . $101100001101,100011111011011101100,0101,000000,0111$ 00010110000110110001111101101110110001010000000

11000011011000111110110111011000101000000011100 . $011000111110110111011.000101000000011 \% 000110001$ $000110110001111101101110110001010000 \$ 0011100001$ $011000011011,000111110 \$ 011101.10001,0100000001110$ 0110110001111101101110110001010000000111,0000110 11000111110110111011000101000000011100001100011 10001011000011011000111110110111011000101000000 $110000110110001111101: 10111011000101000000011100$ 10000110110001111101101110110001010000000111000 0011011000111110110111011000101000000.011100001

1000011011000111110110111011000101000000011100 11000111110110111011000101000000011100001100011 $001101100011111011011101100,01010000000,110,0001$ 1011000011011000111110110111011000101000000011 00010110000110110001111101101110110001010000000 1100001101100011111011011101100010100000001110 0110001111101101110110001010000000111000011000 $00011011000111110110111011000101000000011+100001$ 0110000110110001111101101110110001010000000111 0110110001111101101110110001010000000111000011 1100011111011011101100010100000001110000110001

00Q1011000Q1101DQ00111010DD01010DD000DQ100000Q0 11000011011000111110110111011000101000000011100 0110001111101101110110001010000000111000011000 00011011000111110110111011000101000000011100001 0110000110110001111101101110110001010000000111 0110110001111101101110110001010000000111000011 1100011111011011101100010100000001110000110001 1000101100001101100011111011011101100010100000 1100001101100011111011011101100010100000001110 1000011011000111110110111011000101000000011100 0011011000111110110111011000101000000011100001 